\title{
Uma experiência de Inferência Estatística Informal na Escola Básica
}

Vinicius Alves Rodrigues

DISSERTAÇÃO APRESENTADA
AO
INSTITUTO DE MATEMÁTICA E ESTATÍSTICA
DA
UNIVERSIDADE DE SÃO PAULO
PARA
OBTENÇÃO DO TÍTULO
DE
MESTRE EM CIÊNCIAS

Programa: Mestrado Profissional em Ensino de Matemática Orientador: Prof. Dr. Marcos Nascimento Magalhães 


\section{Uma experiência de Inferência Estatística Informal na Escola Básica}

Esta é a versão corrigida da dissertação elaborada por Vinicius Alves Rodrigues, tal como submetida à Comissão Julgadora no dia 14/12/2016. Uma cópia da versão original da dissertação está disponível no Instituto de Matemática e Estatística

Comissão Julgadora:

- Prof. Dr. Marcos Nascimento Magalhães (orientador) - IME-USP

- Prof ${ }^{\mathrm{a}}$. Dr ${ }^{\mathrm{a}}$. Lisbeth Kaiserlian Cordani - IME-USP

- Prof ${ }^{\mathrm{a}}$. Dr ${ }^{\mathrm{a}}$. Cileda de Queiroz e Silva Coutinho - PUC-SP 


\section{Agradecimentos}

Gostaria de iniciar meus agradecimentos a Deus, por ter me dado à oportunidade para vencer os desafios ao longo deste caminho. Sem Ele, certamente, não teria forças para passar no vestibular e, depois, me encantar com a área da Matemática e seguir na pósgraduação.

Ao meu orientador, que desde a graduação até a pós-graduação, sempre fascinou pela sua dinâmica de atuar nas aulas. Estimulando assim, meu interesse pela Estatística e tendo a quem espelhar para ser um professor melhor. Também a sua paciência e disponibilidade de corrigir, anotar, aconselhar, revisar e ajudar, fatores estes fundamentais para a conclusão dessa dissertação.

A todos os docentes do IME-USP, que apesar das minhas inúmeras dificuldades no início da graduação, sempre acreditaram no meu potencial e incentivaram, de uma forma que eu, conseguisse chegar a um lugar no qual nunca acreditei que seria capaz de alcançar. A vocês, muito Obrigado!

Ao programa de Pós-Graduação de Mestrado Profissional em Ensino de Matemática do Instituto de Matemática e Estatística da Universidade de São Paulo, seu corpo docente, direção e administração, que ajudaram e auxiliaram nesta jornada.

Aos meus pais, Carlos e Lena, pelo amor, carinho e incentivo que sempre tiveram. A vocês, que muitas vezes deixaram de realizar seus próprios desejos em virtudes dos meus. Ao meu pai, pela sua honestidade e pessoalidade, que me ensinou valores da vida. À minha mãe que nunca deixou de confiar em mim. Amo vocês, de coração, Muito Obrigado!

Aos meus Amigos, Familiares e Alunos que, acreditaram, apoiaram e incentivaram, para que eu conseguisse chegar até aqui.

Muito Obrigado a todos vocês! 



\section{Resumo}

RODRIGUES, V. A. Uma experiência de Inferência Estatística Informal na Escola Básica. 2016. Dissertação - Instituto de Matemática e Estatística, Universidade de São Paulo, São Paulo, 2016.

Esta é uma dissertação do Programa de Mestrado Profissional em Ensino de Matemática, do Instituto de Matemática e Estatística da Universidade de São Paulo. A pesquisa proposta se enquadra na linha de pesquisa Estatística no Ensino Fundamental e Médio. Será analisado o desenvolvimento de tópicos de Inferência Informal via um ambiente de investigação em um experimento de sala de aula, dentro do contexto da Educação Básica. Usamos os estudos feitos sobre investigação de Ponte (2007), que serão relacionados com as características do pensamento sobre Inferência Informal estudadas por Makar e Rubin (2009). Para o desenvolvimento do conteúdo de Estatística foi feito uma dinâmica em grupo com o auxilio de três folhas de atividades. Para a análise foram aplicados Testes de Atitudes e Testes de Conteúdos ambos aplicados em dois momentos, no início e no final das atividades. Os resultados indicaram que a proposta apresentada proporcionou uma dinâmica interessante entre os estudantes, aumentando o interesse e a motivação. O material desenvolvido nesta dissertação ficará acessível a todos os professores e pode contribuir na direção da melhoria do aprendizado de conceitos Estatísticos na Educação Básica.

Palavras-chave: amostra; educação básica; inferência informal; população. 



\section{Abstract}

RODRIGUES, V. A. A Statistical Inference Informal experience in High School. 2016. Dissertation - Instituto de Matemática e Estatística, Universidade de São Paulo, São Paulo, 2016.

This is a dissertation in the Professional Master Program in Teaching Mathematics of Institute of Mathematics and Statistics at the University of São Paulo. This is part of research line called Statistical in elementary, middle and high schools. It will be analyzed the development of Informal Inference topics via a research environment in a classroom experiment, within the context of Basic Education. We will use the inquiry studies of Ponte (2007) connecting to thinking characteristics of Informal Inference mentioned by Makar and Rubin (2009). For the development of the Statistical contents the students work in group with the help of three activity sheets. For the analysis we applied Attitudes and Contents Tests in two moments, at the beginning and end of the activities. The results indicated that the proposal provided better relationship among students, increasing their interest and motivation. The material developed in this dissertation will be accessible to all teachers and it can contribute to improve the learning of Statistics concepts in Basic Education.

Keywords: sample; basic education; informal inference; population. 



\section{Sumário}

Lista de Figuras...........................................................................................................

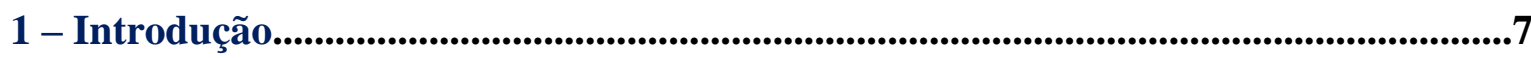

2 - Referencial Teórico............................................................................................................11

2.1 - Estrutura para as Investigações........................................................................12

2.2 - Inferência Estatística Informal...........................................................................

2.3 - A aprendizagem da Inferência Estatística Informal em um Cenário de

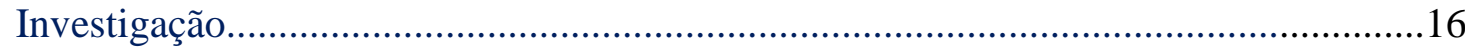

3 - Metodologia ..................................................................................................................................19

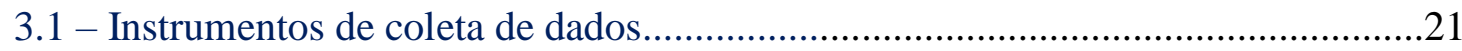

3.2 - Avaliação da Atividade...................................................................................22

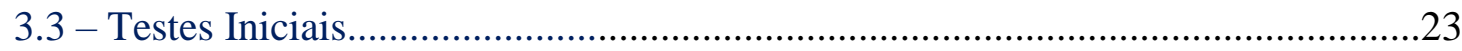

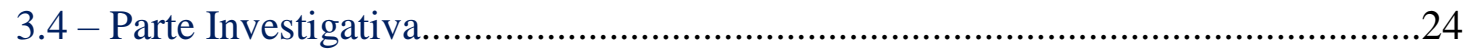

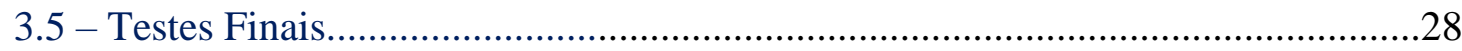

4 - Análise..............................................................................................................29

4.1 - Parte Investigativa..........................................................................................

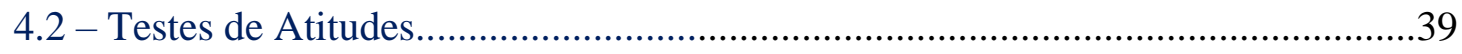

4.3 - Testes de Conteúdos..........................................................................................43

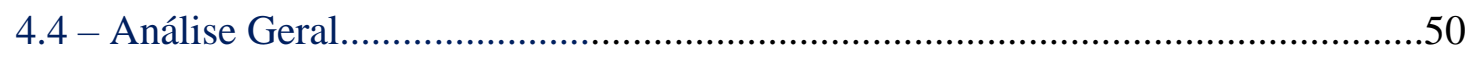




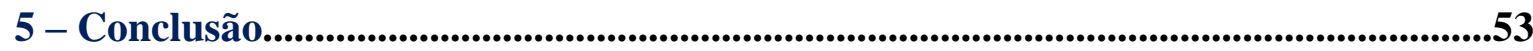

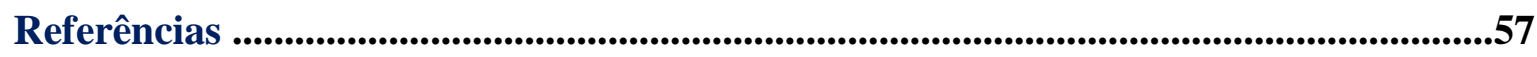

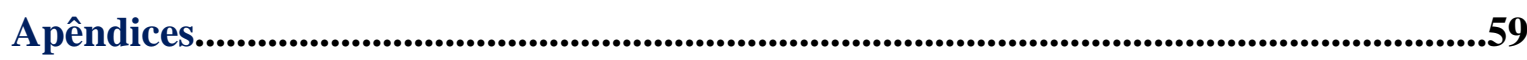

Apêndice 1 - Folha de Atividade 1......................................................................59

Apêndice 2 - Folha de Atividade 2 .................................................................61

Apêndice 3 - Folha de Atividade 3 ...................................................................63

Apêndice 4 - Teste Inicial de Atitudes..................................................................65

Apêndice 5 - Teste Final de Atitudes.......................................................................67

Apêndice 6 - Teste Inicial de Conteúdo...................................................................69

Apêndice 7 - Teste Final de Conteúdo..................................................................

Apêndice 8 - Termo de Consentimento da Escola.....................................................73

Apêndice 9 - Termo de Consentimento do Aluno.....................................................75

Apêndice 10 - Termo de Consentimento dos Responsáveis.......................................77

Apêndice 11 - Resultados dos Testes de Atitudes....................................................79

Apêndice 12 - Análise por pergunta do Teste de Atitudes........................................83 


\section{Lista de Figuras}

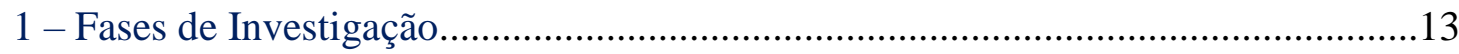

2 - Cenário de Investigação dentro da Inferência Estatística Informal........................18

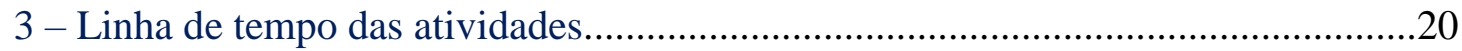

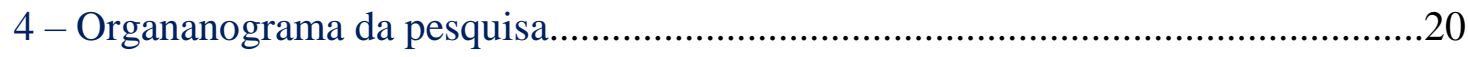

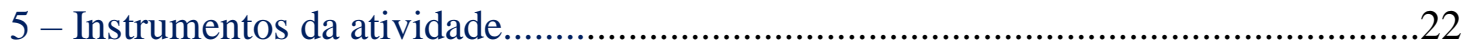

6 - Folha de Atividade 2 - Erro de conceito: População e Amostra..............................31

7 - Folha de Atividade 2 - Coleta de Dados................................................................33

8 - Folha de Atividade 3 - Extrapolação dos Resultados..........................................36

9 - Folha de Atividade 3 - Critério de Variabilidade...................................................38

10 - Teste de Atitudes - Grupo das perguntas Positivas...........................................41

11 - Teste de Atitudes - Grupo das perguntas Negativas..........................................42

12 - Teste de Atitudes - Grupo Geral das perguntas...............................................43

13 - Teste Inicial de Conteúdo - Erro no Plano Cartesiano...........................................44

14 - Teste Inicial de Conteúdo - Exemplo de erro...................................................45

15 - Teste Inicial de Conteúdo - Questões 4 e 5......................................................46

16 - Notas do Teste Inicial de Conteúdo................................................................47

17 - Teste Final de Conteúdo - Erro de análise........................................................48

18 - Teste Final de Conteúdo - Adaptação do ENEM..................................................49

19 - Teste de Atitudes - Gostar de Estatística............................................................83

20 - Teste de Atitudes - Uso de Estatística no Cotidiano.............................................84

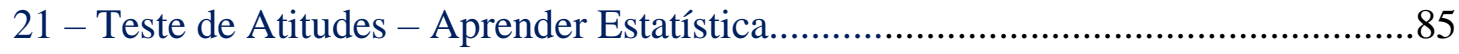

22 - Teste de Atitudes - Entender as informações Estatísticas.....................................86 
23 - Teste de Atitudes - Interesse em usar Estatística................................................87

24 - Teste de Atitudes - Novo jeito de pensar para estudar Estatística.......................88

25 - Teste de Atitudes - As estatísticas são raramente presentes na vida real.............89

26 - Teste de Atitudes - Estatística é uma matéria difícil..........................................90

27 - Teste de Atitudes - Insegurança nos problemas de Estatístic..............................91

28 - Teste de Atitudes - Estatística é irrelevante para a vida.....................................92

29 - Teste de Atitudes - Dificuldade em compreender os conceitos de Estatística.....93

30 - Teste de Atitudes - Eu fico assustado com Estatística.......................................94 


\section{Capítulo 1}

\section{Introdução}

Desde as últimas décadas, vivemos uma tentativa de inserção do ensino de Estatística na Educação Básica do país. Muitos avanços já foram conseguidos, como as sugestões para a inclusão de tópicos de Estatística no currículo da disciplina de Matemática na Educação Básica, conforme os Parâmetros Curriculares Nacionais (Brasil-MEC, 1997), e também, o crescimento da área de pesquisa em Educação Estatística, conforme Lopes et al (2010). Porém, muitos problemas ainda precisam ser resolvidos.

Como destaca Lopes (2008), vários professores de Matemática têm dificuldade de ensinar os conceitos de Estatística em sua amplitude, isso devido à formação teórica deficiente na área, à falta de aprofundamento dos conhecimentos didáticos e à ausência de reflexão da prática docente. Além disso, é comum encontrarmos nos materiais didáticos e nas aulas práticas em sala de aula uma ênfase generalizada nos cálculos numéricos e não no significado dos conceitos estatísticos. Sendo assim, os estudantes acabam por não perceber a Estatística como uma ciência que lhes permite organizar, coletar e analisar os dados gerados pela sociedade.

A educação, em geral, também precisa se adaptar. O jovem do século XXI se vê muito mais voltado para práticas virtuais e dinâmicas, consequentemente, pouco se dispõe e se interessa pelos métodos de ensino tradicionais. A falta de inovação nas aulas também acaba por desmotivar os alunos na escola, que se veem presos em uma rotina de aulas teóricas e exercícios, que não trazem significado algum para sua vida. Portanto há a necessidade da inovação, de novos métodos de ensino para promover o aprendizado com significado para o aluno.

A presente pesquisa envolve uma dinâmica em sala de aula, que coloca o educando

como principal agente no desenvolvimento de seu conhecimento. Programamos uma sequência didática que envolve uma atividade de inferência informal a ser aplicada na 
Educação Básica. Faremos uma avaliação do aprendizado dos alunos, do trabalho do professor e da metodologia proposta.

A motivação para esta pesquisa surgiu de constatações das dificuldades enfrentadas pelas pessoas para se comunicarem e analisarem situações que envolvam dados e suas referências. Isto, em parte, pode ser explicado pelo aparecimento tardio da Estatística como parte obrigatória no ensino básico do Brasil em contraste com o cenário internacional. Como mencionado em Lopes et al (2010): "Segundo Pfannkuch (2008) o ensino e a aprendizagem da Estatística têm sido alvos de preocupações e pesquisas no cenário internacional desde a década de 90 , com o objetivo de promover o desenvolvimento do pensamento estatístico nos alunos". No Brasil, os Parâmetros Curriculares Nacionais (Brasil - MEC, 1997) sugerem a abordagem clara de conteúdos e conceitos de Estatística. Desde então, muitos estudos têm sido desenvolvidos e a área se encontra em expansão, produzindo projetos de pesquisas em cursos de mestrado, doutorado e pós-doutorado.

A Inferência Estatística é uma área extensa e com técnicas que envolvem conceitos avançados sobre variáveis aleatórias que não são previstos no currículo da Educação Básica. Entretanto, desde o início do século XXI, muitos pesquisadores começaram a desenvolver uma nova linha de pesquisa que lida com os principais conceitos e tipos de argumentos de cunho indutivo relativos à Inferência Estatística, mas sem o uso de seu maquinário formal. A ideia é focar na discussão preliminar do assunto, tornando-o explorável na Educação Básica, criando a chamada Inferência Estatística Informal. Para uma reflexão mais profunda sobre as ideias envolvidas na Inferência Estatística Informal consulte Zieffler et al (2008).

No cenário nacional, a recente dissertação de mestrado de Camargo (2016) trata sobre a prática docente em sala de aula quando os alunos aprendem os conceitos de Estatística e traz a abordagem da Inferência Informal como um estudo que pode facilitar a compreensão dos alunos.

As pesquisas sobre Inferência Estatística Informal estão em crescimento. Apesar de alguns trabalhos acadêmicos não carregarem esta nomenclatura eles utilizam raciocínios informais para produzirem alguma inferência. Outras iniciativas da fomentar a utilização 
da Inferência Informal em sala de aula estão sendo feitas em cursos de formação de professores como é o caso das oficinas de Cordani (2005) e Magalhães (2014).

Esta dissertação avalia o efeito de uma sequência didática envolvendo uma atividade de inferência informal para o ensino de conceitos estatísticos na Escola Básica. Pretendemos que esta sequência, a ser disponibilizada a todos os professores posteriormente, permita que o docente possa aplicá-la em sua sala de aula. Tendo em vista o cenário atual do ensino de Estatística, formularemos as seguintes perguntas de pesquisa:

Pergunta 1: Podemos estimular os alunos, partindo da Inferência Estatística Informal e dentro de uma aula de investigação, a desenvolver afirmações de cunho indutivo?

Pergunta 2: Por meio de um experimento de inferência informal em sala de aula, os alunos conseguirão desenvolver atitudes positivas em relação à Estatística?

Pergunta 3: Os estudantes conseguirão compreender os significados básicos da Inferência Estatística Informal?

Em resumo, esperamos avaliar se uma aula estruturada em um ambiente de investigação, pode auxiliar no desenvolvimento do raciocínio informal dos alunos e contribuir para a construção de conceitos de Estatística com significado. 


\section{Capítulo 2}

\section{Referencial Teórico}

O presente quadro teórico está alicerçado nos estudos feitos sobre investigação de Ponte (2007) e que serão relacionados com as características do pensamento sobre inferência informal estudadas por Makar e Rubin (2009).

Para descrever os conceitos estatísticos que serão trabalhados na atividade, recorreremos às discussões sobre as ideias fundamentais da Matemática descritas por Machado (2015) em conjunto com as grandes ideias da Estatística, propostas por Garfield e Ben-Zvi (2008).

A avaliação da aprendizagem dos alunos será baseada nas discussões sobre pesquisas qualitativa e quantitativa. Faremos uso de testes de conteúdo (questões dissertativas e alternativas), gravações de áudio das aulas e análise das anotações dos alunos nas folhas de atividades. Utilizaremos um teste de atitude adaptado do questionário desenvolvido pelo grupo SATS-36 (2005) sobre as atitudes dos alunos em um curso de Estatística. 


\subsection{Estrutura para as Investigações}

O processo de investigação é o que mais se assemelha ao trabalho do cientista na academia envolvido no fazer da Matemática. Não estamos defendendo que o aluno deva se tornar ou fazer um trabalho análogo à de um profissional de pesquisa, mas que ele possa vislumbrar o quanto é interessante este processo, de testar, argumentar e formular hipóteses.

De modo geral um matemático profissional lida diretamente com as ideias sobre hipóteses, definições e demonstrações, que estão todas intimamente ligadas ao desenvolvimento do raciocínio lógico e da linguagem matemática. Na Escola Básica alguns alunos pensam que a Matemática é apenas ficar fazendo contas e utilizando fórmulas sem sentido nenhum, sem explicações e que surgiram por algum raciocínio inviável à sua capacidade de compreensão. Infelizmente, este viés, acabou se estendendo também para o ensino de Estatística.

Uma investigação tem a característica de ser uma questão em aberto que envolve uma perplexidade em seu caminho. Isto pode assustar alguns professores que não se sentem seguros com este tipo de atividade, pois em um cenário de investigação temos a exploração de uma questão em uma estrutura aberta e muitos caminhos podem ser seguidos. Não há como saber todas as possibilidades e se preparar para elas. Isto rompe com a ideia de aula tradicional, quando o docente sabe exatamente com o que pode se deparar. Diferentemente, em uma atividade de investigação, podem surgir várias frentes e não existe um caminho pré-estabelecido. A ideia não é deixar os alunos perdidos, mas sim orientá-los em um caminho desejável, sem perda de autonomia.

Uma atividade envolvida em um cenário de investigação deve ser uma viagem até algo desconhecido a partir de um problema ou experiência motivadora. O importante a salientar é que, diferentemente de um problema, na exploração de uma atividade investigativa, o destaque é para o caminho que estamos percorrendo e não a resposta ao problema. De acordo com Ponte (2007) “como diz Susan Pierie (1987) o importante é explorar um aspecto da Matemática em todas as direções. O objetivo é a viagem e não o destino". Neste contexto, é que Crhistiansen e Walther (1986) descrevem uma estrutura 
para aulas de investigações, que envolvem as seguintes fases: Introdução da Tarefa, Desenvolvimento do Trabalho e Discussão Final e Reflexão.

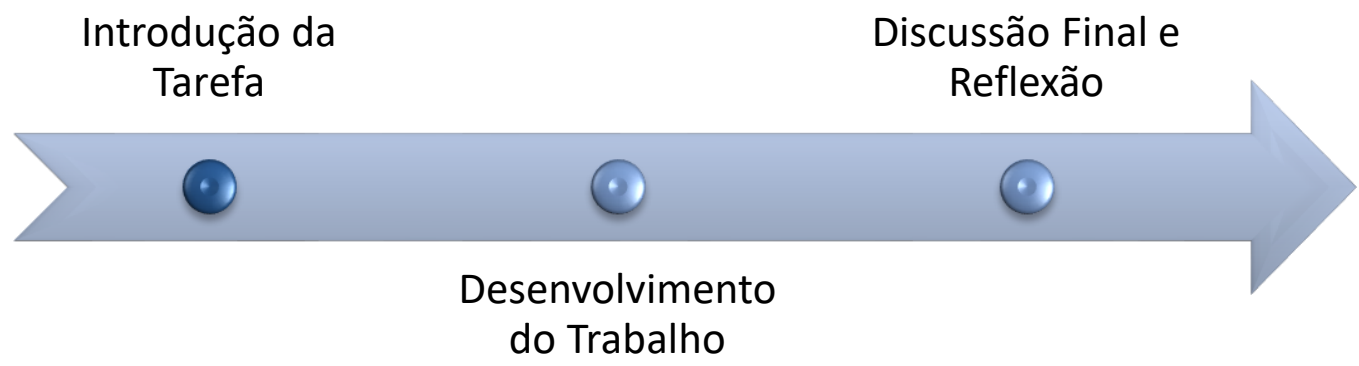

Figura 1: Fases da Investigação

A Introdução da Tarefa pode ser feita de várias maneiras, porém com foco sempre no desenvolvimento dos alunos sobre os conceitos. Pode ser uma leitura em grupo, assistir um vídeo, ou uma aula de exercícios. Essa fase deve conseguir despertar o interesse do aluno no tema. Caso o aluno ainda não conheça ou não tenha participado de alguma atividade que passe pelas três fases de investigação, é nesta primeira fase, da Introdução da Tarefa, que o docente deve ter bastante cautela para não desmotivar o aluno logo no início.

Na fase Desenvolvimento do Trabalho os alunos iniciam a ação investigativa. Durante esta fase, e diferente da anterior, o professor entra como um orientador da atividade e o foco da investigação caberá aos alunos. O processo investigativo nesta fase envolve: compreender a situação proposta, organizar os dados e formular perguntas. Em alguns casos, é aqui que os estudantes propõem as afirmações sobre tendências ou padrões dos dados, discutem os resultados obtidos, e dependendo da dinâmica e dos alunos, podem até chegar a perceber alguns modelos matemáticos que sejam úteis para descrever uma determinada situação.

Na Discussão Final e Reflexão, o professor deve incentivar os alunos a responder perguntas do tipo: o que parece que vai acontecer com os dados? Você percebe alguma categoria, classificação, modelo ou regra? Será que é mesmo assim? É importante que os alunos consigam se comunicar e argumentar com convicção sobre os resultados obtidos. O 
estudante deve ser capaz de expressar o que pensou daquele resultado, quais processos ou evidências o levaram à sua argumentação e justificativa sobre a relevância para o estudo que está sendo feito.

\subsection{Inferência Estatística Informal}

A Inferência Estatística é uma área importante da Ciência. Sua potencialidade de poder, a partir dos dados amostrais, inferir resultados para a população inteira de estudo nos permite resolver diversos problemas. Vivemos na era da informação e cada vez mais se faz necessário que os alunos entendam os princípios desta área.

Machado (2015, p.2) diz que "Em geral, uma ideia fundamental de uma disciplina nunca é isolada, nem estritamente disciplinar; em razão disso, articula internamente a disciplina que se ensina, e, ao mesmo tempo, favorece sua interação com as demais disciplinas curriculares". Neste caso, Machado descreve doze ideias fundamentais agrupadas em pares, sendo elas: Equivalência e Ordem; Proporcionalidade $e$ Interdependência; Medições e Aproximação; Invariância e Variação; Periodicidade e Aleatoriedade; Problematicidade e Otimização.

Neste trabalho, focaremos na ideia Aleatoriedade, como o autor descreve: "A toda hora, todos os dias, vivemos o embate do par determinístico/aleatório, em nossas ações mais ordinárias. Da previsão do tempo às notícias sobre o trânsito, passando pelas cotações da Bolsa e pelas variações de nossos humores, o modo como tomamos algumas das decisões mais importantes de nossas vidas (namorar ou casar, por exemplo) encontra-se frequentemente impregnado pelo acaso. A Estatística surge como recurso para a projeção em situações onde o acaso predomina, mas a domesticação do acaso não significa, em hipótese alguma, a aniquilação do mesmo".

O ensino focado nas ideias fundamentais serve como uma boa estratégia para o aprendizado dos alunos. Os estudantes compreendem melhor um conceito quando ele se conecta com as demais áreas do conhecimento e inicia-se a partir de algo que o educando 
já conheça. A Estatística é uma área que facilita o trabalho com as ideias fundamentais devido à sua naturalidade de conexão com as demais disciplinas da Escola Básica.

Em consonância com esta linha de raciocínio Garfield e Ben-Zvi (2008) descrevem as grandes ideias que permeiam a Estatística, a saber: Dados, Modelos, Distribuição, Centro, Variabilidade, Comparação entre Grupos, Amostragem, Inferência Estatística e Covariação. Também destacam que "Aprender e manter as grandes ideias requer que sejam explicitamente relacionadas em diferentes contextos (e temas) depois de serem introduzidas. Isso também envolve a transferência de conhecimentos a partir de situações anteriores para aplicações futuras" (tradução nossa).

Segundo os mesmo autores, ao iniciar o trabalho com as grandes ideias da Estatística deve-se observar que "Aprender as grandes ideias da Estatística requer um desmembramento das ideias em componentes que começam com noções informais, que são baseadas e influenciadas pelo conhecimento e intuições prévias dos alunos, para construir gradualmente as noções formais“ (tradução nossa).

A Inferência Estatística Informal lida com a maneira como as pessoas produzem raciocínios e resultados inferenciais sem a devida formalização teórica correspondente. Por exemplo, quando elas saem para trabalhar e tentam prever o tempo que vão gastar para chegar ao serviço, quando planejam um roteiro para cada etapa do dia, ou ainda, ao prever o clima antes de sair de casa, ao escolher o local para passar as férias, ou estimar o horário dos convidados chegarem a uma festa. Essas são situações, entre outras, em que fazemos inferências.

Seria muito difícil trabalhar com a inferência formal na escola básica, pois isto envolve um estudo mais apurado das funções de probabilidade, modelos estatísticos e resultados de assuntos não previstos, neste momento, para a Escola Básica. Neste cenário é que começaram os estudos sobre Inferência Estatística Informal.

Segundo o WolfWikis (versão do Wikipédia da Universidade da Carolina do Norte) as pesquisas nesta área ganharam força a partir do início dos anos 2000. Zieffler et al (2008) destacam alguns componentes que envolvem a inferência informal: 
- Analisar as possíveis características de uma população baseado na observação de uma amostra.

- Entender as possíveis diferenças entre duas populações baseado em diferentes observações de duas amostras dos dados.

- Avaliar se uma determinada amostra de dados foi inadequada tendo em vista certa expectativa de resultado.

- Fazer julgamentos, afirmações, articulações, ou previsões sobre populações baseado em amostras, mas não utilizando procedimentos formais de estatística.

(tradução nossa)

\subsection{A aprendizagem da Inferência Estatística Informal em um Cenário de Investigação}

No cenário de pesquisas sobre Inferência Estatística Informal, Makar e Rubin (2009) apresentam características para o desenvolvimento do pensamento envolvido na abordagem inicial sobre inferência estatística. Os autores indicam três componentes para o desenvolvimento do pensamento dos alunos sobre inferência informal: Dados como evidência, Compreensão para além dos Dados e Linguagem Probabilística.

Em Dados como evidência a coleta dos dados em um contexto determinado é utilizada para fornecer uma explicação implícita ou explícita de uma inferência que está sendo feita. A Compreensão para além dos Dados se dá quando o aluno olha para os dados que tem em mãos e faz alguma inferência para uma população em específico. Por último, a Linguagem probabilística aparece quando o aluno descreve a situação com detalhes probabilísticos, incluindo avaliar se a inferência feita foi razoável ou não.

As características descritas por Makar e Rubin (2009) emergiram das pesquisas sobre o pensamento inferencial dos alunos e sua relação com os processos de investigação. Foram detalhados por Wild e Pfannkuch (1999) os ciclos de investigação em Estatística. Hancook et al (1992) e Pratt e Ainley (2008), entre outros pesquisadores, ligaram os conceitos da inferência estatística com os processos de investigação. Para eles, o pensamento inferencial e a investigação não podem ser separados. 
Em um cenário de investigação, precisamos primeiramente de um tema, ou contexto, que consiga criar problemas abertos que podem ser investigados. Para tanto, formulamos afirmações sobre a questão de interesse, em seguida, fazemos a coleta de dados e, com ferramentas adequadas, vamos extraindo informações que possam descrever o problema investigado. Por fim, propomos uma solução, uma resposta, ou descartamos o que formulamos.

As três fases de investigação descritas por Christiansen e Walther (1986, p.13), ver Figura 1, podem se conectar com os três componentes das características propostas por Makar e Rubin (2009), reorganizadas, objetivando o ensino da Inferência Informal.

Na Introdução da Tarefa, percebemos o destaque para a discussão da questão de investigação, com o que propor para ser investigado, os métodos utilizados, a coleta de dados, o levantamento de afirmações, questões estas que estão relacionadas com o uso dos Dados como evidência, um dos componentes propostos para o pensamento da Inferência Informal.

No Desenvolvimento do Trabalho dentro do cenário de investigação temos a realização dos testes, a visualização dos dados, a percepção de padrões no detalhamento das informações obtidas, tudo isto se conecta com outro componente da Inferência Informal, a Compreensão para além dos Dados.

Ao trabalhar com a última fase de um processo de investigação, a Discussão Final e Reflexão, se investigam os argumentos dos alunos para explicar ou refutar a afirmação inicial. Identificamos por meio da fala dos estudantes as possíveis generalizações dos resultados e assim, percebemos a ligação com o último componente da Inferência Informal, a Linguagem Probabilística. É no momento final de discussão sobre a inferência que a linguagem probabilística aparece nas explicações dos estudantes.

Sendo assim, neste trabalho propomos uma organização estrutural para o desenvolvimento de um cenário de investigação dentro da Inferência Estatística Informal, que será resumido no quadro abaixo: 


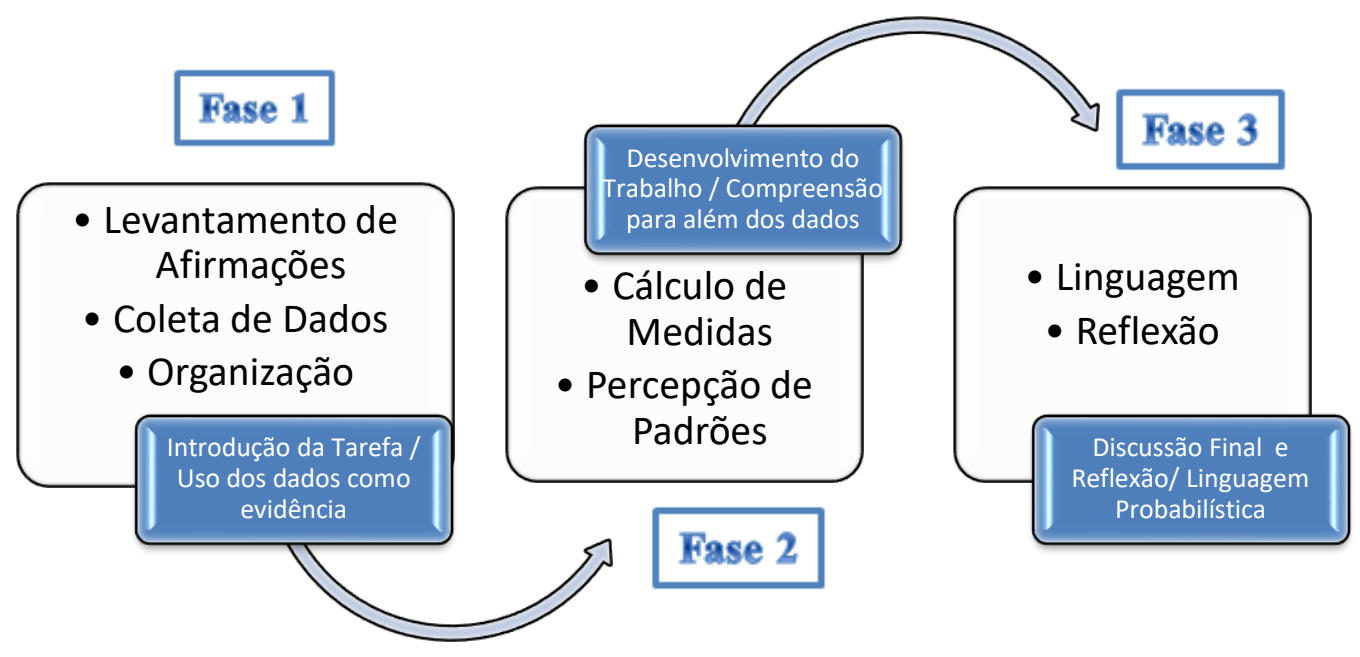

Figura 2: Cenário de Investigação dentro da Inferência Estatística Informal. 


\section{Capítulo 3}

\section{Metodologia}

Os Parâmetros Curriculares Nacionais, ver Brasil-MEC (1997), indicam que os conceitos estatísticos devem ser trabalhados na Escola Básica desde o Ensino Fundamental I, dessa forma, podemos desenvolver a atividade desta pesquisa com os alunos do Ensino Médio.

De acordo com a proposta curricular do Estado de São Paulo (2008), o contato com os conceitos inferenciais de Estatística deve ser visto no $4^{\circ}$ bimestre do $3^{\circ}$ ano do Ensino Médio. Nas redes Estaduais de ensino este seria o momento adequado para trabalhar com os estudantes as noções básicas sobre inferência estatística de um ponto de vista informal.

Tendo em vista a especificidade dos sistemas de ensino em cada escola, para o melhor aproveitamento dos alunos durante as fases de investigação que propomos, recomendamos que os alunos já tenham contato com os seguintes conceitos: gráficos, tabelas, frequências, medidas de tendência central e probabilidade.

No desenvolvimento da sequência didática será fornecido todo o material para os alunos. A duração da atividade tem previsão de seis aulas, no decorrer de dois meses, conforme organograma nas Figuras 3 e 4. Será utilizada uma aula, para os Testes Iniciais, podendo ser feita no horário das aulas ou em outro momento oportuno. Quatro aulas lidam com a Parte Investigativa, que está subdividida em três fases: Introdução da Tarefa, Desenvolvimento do Trabalho, Discussão Final e Reflexão. Por último, será utilizada uma aula para a aplicação dos Testes Finais. 


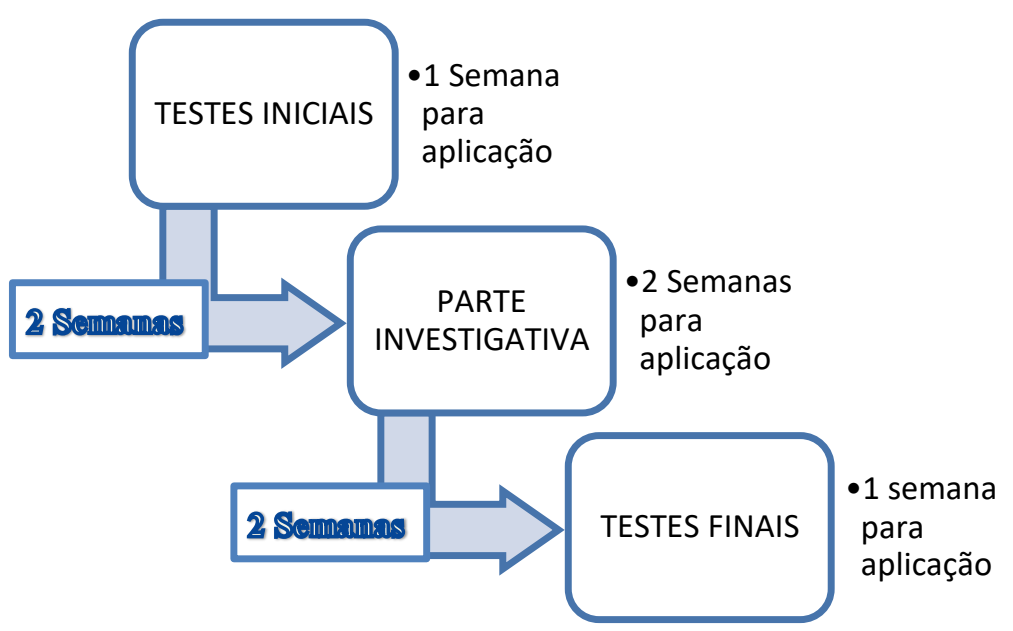

Figura 3: Linha do tempo das atividades

Notemos que as semanas na descrição da linha do tempo correspondem ao tempo necessário para a aplicação de um item e o intervalo para a realização do item seguinte. Por exemplo, para os "Testes Iniciais" temos 1 semana para a aplicação e um intervalo de 2 semanas entre as atividades. Assim o professor, tem duas semanas para corrigir os trabalhos, entregar para os alunos, rever algo necessário, até iniciar a "Parte Investigativa".

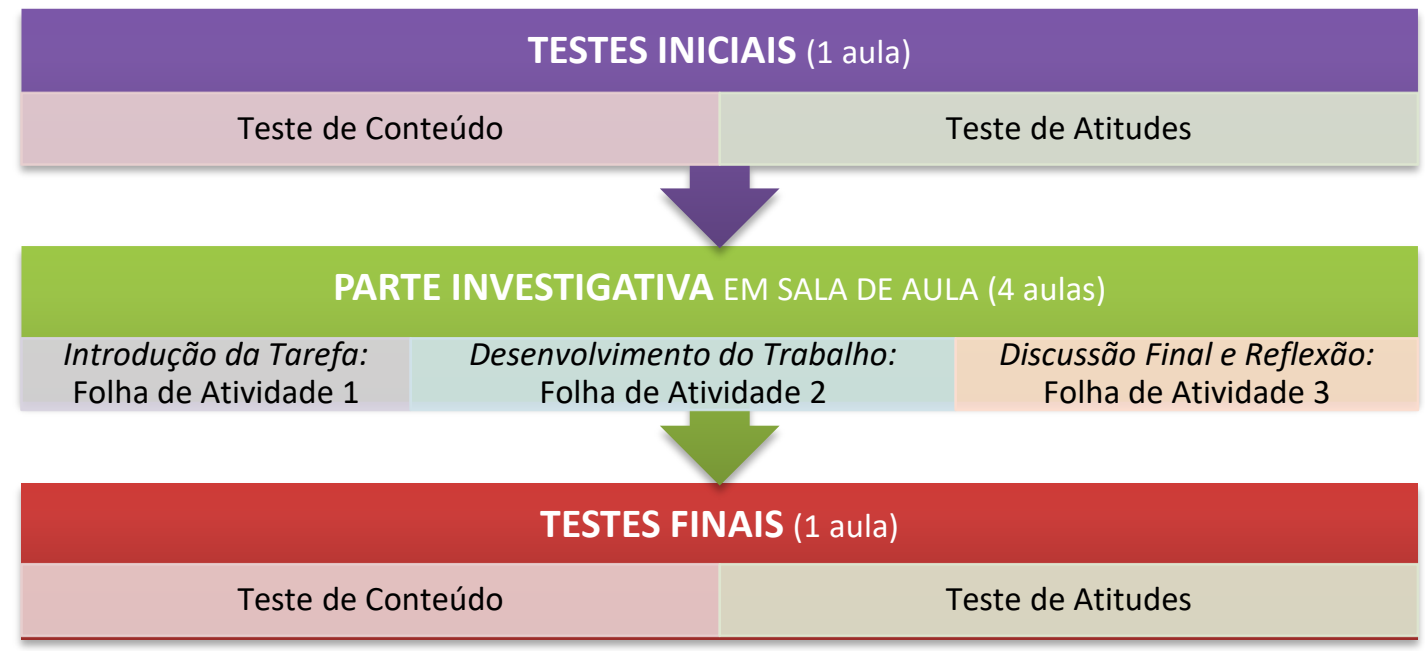

Figura 4: Organograma da pesquisa 


\subsection{Instrumentos de coleta de dados}

Diversos são os instrumentos procedimentais que existem para a elaboração de uma pesquisa. A escolha deles guiará a pesquisa e seus resultados, bem como seu alcance, em termos de aplicações, efeitos e conclusões. No nosso caso, utilizaremos alguns instrumentos da pesquisa qualitativa e quantitativa, que serão detalhados a seguir.

Como parte dos procedimentos, será realizada uma análise qualitativa ao longo da aplicação da Parte Investigativa com os alunos gravando suas discussões nos grupos e a interação com o professor. Na parte quantitativa serão realizados dois testes, um para verificar os conteúdos e outro para as atitudes em relação à Estatística. Cada um desses testes será aplicado em duas ocasiões, uma no início e outra no final da atividade.

Ao longo da Parte Investigativa, o professor deve tomar cuidado para não influenciar nas respostas dos alunos e os mesmos devem ficar à vontade com o fato da conversa entre eles estar sendo gravada. Cada grupo contará com um representante, que gravará a conversa do grupo e ficará responsável por disponibilizar o áudio posteriormente para análise. O professor pode antes da atividade fazer alguns testes de gravação visando diminuir a inibição dos alunos. Utilizaremos nomes fictícios, tanto para a Escola, quanto para os estudantes, para evitar constrangimentos e obter respostas mais confiáveis.

O Teste de Atitudes será aplicado com as mesmas questões no início e no término da atividade ajustando, quando necessário, os tempos verbais (ver Apêndices 4 e 5). Já o Teste de Conteúdo, também será aplicado no início e no término da pesquisa, porém na aplicação final será alterada a dificuldade das questões. 


\subsection{Avaliação da Atividade}

A avaliação é uma forma de tentar mensurar quanto um objetivo foi alcançado, e com base nestas informações, planejar ou replanejar as metas inicialmente propostas, que são estabelecidas na organização da metodologia de trabalho.

A observação dos objetivos da atividade se baseará na análise dos instrumentos utilizados. Os dados do Teste de Atitudes e das Folhas de Atividades estarão disponíveis nos Apêndices. De acordo com a Figura 5, os instrumentos estão divididos em qualitativos e quantitativos.

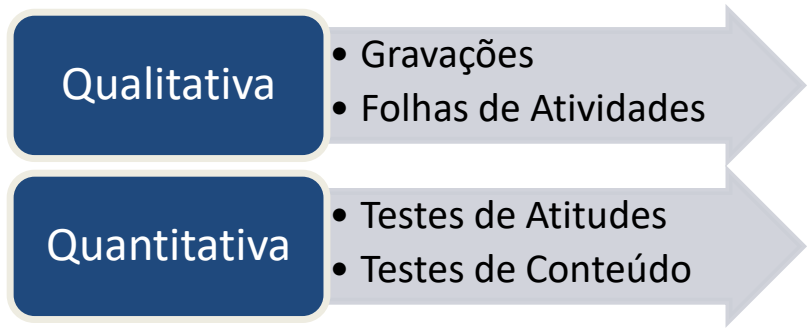

Figura 5: Instrumentos da atividade

$\mathrm{Na}$ avaliação das gravações daremos atenção especial para as falas que mostrem o desenvolvimento do vocabulário dos estudantes por meio da linguagem técnica utilizandose de termos e conceitos probabilísticos. Também será verificada a apropriação dos conceitos estatísticos no decorrer da Parte Investigativa.

A solução das Folhas de Atividades será indicada pelo professor em sala de aula, mas serão os alunos que farão as devidas correções e atribuirão um conceito para a sua atividade. Os estudantes devem indicar e justificar os critérios que utilizaram para as correções. Para a atribuição dos conceitos usou-se MB (muito bom), B (bom), R (regular) e I (insatisfatório).

Nos registros dos alunos sobre as resoluções será analisado o progresso dos estudantes na compreensão dos conceitos estudados. Os Testes de Conteúdo e as Folhas de Atividades serão analisados para destacar os erros e acertos do educando. 
Por último, os dois testes de atitudes, serão representados por meio de gráficos e tabelas. Para efeitos comparativos, utilizaremos a média e o desvio padrão dos resultados para verificar a evolução das notas obtidas no início e no final da sequência didática.

\subsection{Testes Iniciais}

O Teste Inicial de Conteúdo e o Teste Inicial de Atitudes podem ser aplicados na mesma aula e, com intervalo de duas semanas, analisados antes da dinâmica da Parte Investigativa. Dessa forma daremos tempo para alunos assimilarem os conceitos e a oportunidade de tirarem eventuais dúvidas. Os testes iniciais estão nos Apêndices 4 e 6.

As questões do Teste Inicial de Conteúdo visam diagnosticar se os alunos sabem os conceitos necessários para progredirem na sequência das três folhas da Parte Investigativa. São eles: manipulações aritméticas de razões, noções de porcentagem, formação e análise de tabelas e gráficos e as medidas estatísticas, média, moda e mediana.

Já o Teste Inicial de Atitudes versará sobre a existência de atitudes positivas e negativas dos alunos em relação à Estatística. Apesar dos alunos não conhecerem a área da Estatística, eles conseguem mensurar seu interesse pelo assunto, pois não precisa saber de antemão tudo sobre uma área para dizer se nos interessamos por ela ou não. Por exemplo, posso ser incapaz de entender os princípios da Inteligência Artificial, mas, mesmo assim consigo classificar meu interesse no assunto. Contudo, caso o docente ache mais conveniente, o teste pode ser aplicado após duas semanas do início dos assuntos sobre Estatística, sendo assim, os estudantes terão mais discernimento para responderem às questões. 


\subsection{Parte Investigativa}

Na Parte Investigativa, a sequência didática usa em torno de 6 aulas para o desenvolvimento das três Folhas de Atividades, que podem ser encontradas nos Apêndices 1,2 e 3.

O material do aluno está separado em três folhas. Isto serve para organizar o desenvolvimento da Parte Investigativa, seguindo as fases da Figura 1. Na primeira fase, Introdução da Tarefa, os alunos resolvem alguns exercícios da Folha de Atividade 1, que darão suporte para a etapa investigativa. O ideal é que não se gaste mais de uma aula com isso.

Na segunda fase, Desenvolvimento do Trabalho, que diz respeito à dinâmica em grupo com materiais em mãos, a ideia é que os alunos se separem pelos temas escolhidos em seus respectivos grupos para responder às perguntas da Folha de Atividade 2. Esta etapa de coleta, organização e investigação dos dados, deve durar duas aulas.

A terceira fase, Discussão Final e Reflexão, relaciona-se com a análise final da atividade por meio do desenvolvimento da Folha de Atividade 3, que diz respeito à comunicação dos resultados obtidos e deve durar uma aula.

Descrevemos abaixo mais detalhes para o trabalho com as folhas, de acordo com o quadro descrito na Figura 2, contendo os seguintes itens: Objetivos, Introdução da Tarefa, Desenvolvimento do Trabalho, Discussão e Reflexão.

\section{Objetivos}

$\checkmark$ Introduzir os conceitos de população e amostra.

$\checkmark$ Perceber as diferenças entre o tratamento de dados com variáveis qualitativas e quantitativas.

$\checkmark$ Produzir raciocínio informal indutivo sobre a influência do tamanho das amostras.

$\checkmark$ Perceber a necessidade de utilizar procedimentos adequados para coletar amostras.

$\checkmark$ Reconhecer padrões em tabelas e gráficos. 
$\checkmark$ Obter conclusões por meio da inferência informal e a partir da amostra conseguir propor resultados para a população inteira.

\section{Introdução da Tarefa - Fase 1 - Folha de Atividade 1}

A Introdução da Tarefa pode ser feita de várias maneiras, porém com foco sempre no desenvolvimento dos alunos sobre os conceitos. Deve-se ter atenção com este tipo de abordagem inicial com estudantes que não conhecem este processo e, por ser algo diferente do que eles estão acostumados, poderá haver rejeição à atividade. Entretanto, se a atividade de Introdução da Tarefa estiver clara o bastante, e em uma linguagem que os alunos entendam, esta dificuldade ficará minimizada.

O professor deve refletir sobre a sua turma e eleger a melhor abordagem inicial, que inclua uma breve introdução e discussão sobre aleatoriedade, estatística, população e amostra. O importante aqui é preparar o aluno para o processo investigativo e mantê-lo motivado para aprender.

No início das atividades desta fase, o docente deverá selecionar os grupos dos alunos por algumas variáveis de pesquisa, que foram previamente escolhidas pelo professor. Cada grupo deve escolher um par de variáveis para serem investigadas, sendo uma qualitativa e outra quantitativa. No entanto, antes dos estudantes iniciarem a escolha das variáveis de uma listagem, eles podem optar por mudar algumas delas.

\section{Variáveis Quantitativas:}

- Altura dos alunos

- Horas por dia que utiliza a internet

- Número do sapato

- Número de irmãos

- Palma da mão 


\section{Variáveis Qualitativas:}

- Cor do olho

- Tipo do filme favorito

- Principal estilo de música

- Matéria preferida

- Tipo de jogo favorito

Em seguida, a Introdução da Tarefa será realizada pelos alunos em seus respectivos grupos por meio da aplicação da Folha de Atividade 1.

Os alunos devem responder às questões propostas em uma aula. Depois, o professor deve julgar se será necessário fazer um feedback com os estudantes e retomar alguns conteúdos. O objetivo desta fase é que os alunos consigam reconhecer os conceitos de população e amostra e sejam capazes de diferenciá-los em diversos contextos.

\section{Desenvolvimento do Trabalho - Fase 2 - Folha de Atividade 2}

A fase de Desenvolvimento do Trabalho inclui a resolução da Folha de Atividade 2. Primeiramente os alunos compreendem a situação proposta, depois organizam os dados e, por último, formulam perguntas. Em alguns casos, é aqui que eles propõem as afirmações, discutem os resultados obtidos, e dependendo da dinâmica e dos alunos, podem até demonstrá-los.

Durante a primeira semana da Introdução da Tarefa, entre a aplicação dos testes e o início do trabalho com as atividades, o docente deve fazer a coleta de dados para os estudantes analisarem sobre as respectivas variáveis escolhidas pelos grupos para eles analisarem. 
Para a dinâmica em grupo os alunos recebem os pacotes com as respostas sobre as variáveis. Com os estudantes em seus respectivos grupos o professor explicará como deve ser feita a coleta de dados e as respostas na Folha de Atividade II. Um estudante por grupo ficará responsável pela gravação das conversas para entregá-las posteriormente ao professor.

\section{Discussão Final e Reflexão - Fase 3 - Folha de Atividade 3}

Na Discussão Final e Reflexão, última fase da Parte Investigativa, os alunos utilizam a Folha de Atividade 3. Esta fase tem como base a análise das afirmações e extrapolações. O professor deve pedir para os grupos apresentarem seus resultados e as respectivas justificativas.

Será feita uma discussão final com os alunos para que todos possam compartilhar os resultados obtidos. Nesta etapa o professor atua buscando confrontar os alunos com suas afirmações, estratégias e justificativas. Os estudantes são estimulados a explicar suas ideias e a argumentar em defesa de seu ponto de vista. Cabe ressaltar aqui que o docente deve ter sensibilidade e ser capaz de valorizar, tanto as descobertas mais interessantes, quanto as mais modestas.

A atividade pode ser finalizada com a discussão sobre população e amostra e sobre os métodos utilizados pelos grupos para a criação dos intervalos de variabilidade. É interessante comentar sobre o erro de utilizar medidas de variabilidade em variáveis qualitativas. 


\subsection{Testes Finais}

Os testes finais incluem o Teste Final de Conteúdo e o Teste Final de Atitudes. O Teste Final de Conteúdo deve abranger todos os assuntos discutidos na Parte Investigativa e pode ser feito em uma aula. O ideal é que isto ocorra dois meses depois da aplicação da última folha de atividades. Desse modo, podemos ver a capacidade de retenção e assimilação dos conceitos e avaliar se o aprendizado foi de fato significativo para os estudantes. $\mathrm{O}$ intervalo de tempo também é um fator importante para as atitudes em relação à Estatística. Queremos avaliar, se passado algum tempo da realização das atividades, os estudantes mudaram suas atitudes anteriores. 


\section{Capítulo 4}

\section{Análise}

A pesquisa foi realizada em uma escola particular, localizada na Zona Norte de São Paulo, na disciplina de Matemática do $3^{\circ}$ do Ensino Médio ao longo do $2^{\circ}$ bimestre do ano letivo de 2016. Os alunos tiveram um contado anterior rápido com os conteúdos de Estatística. Os assuntos eram deixados por último para serem ensinados e solicitados apenas como um trabalho extra de classe. Dessa forma, foi necessário retomar os conceitos iniciais de gráficos, tabelas e medidas de tendência central para iniciar as atividades.

O docente responsável pela disciplina de Matemática, neste caso, é o próprio pesquisador. Não houve conflito entre o eu "professor" e "pesquisador" e foi possível realizar as tarefas regulares de ensino e, também, viabilizar a coleta de dados para a pesquisa.

Antes da aplicação da atividade todos os envolvidos, alunos, responsáveis e o diretor da escola manifestaram, por meio de um termo de consentimento, acordo para a participação na pesquisa que estava sendo elaborada. Não houve, de nenhuma parte, recusa na assinatura dos termos de consentimento, cujos modelos podem ser encontrados nos Apêndices 8, 9 e 10. Todas as autorizações estão arquivadas e disponíveis para verificação via solicitação ao pesquisador.

A atividade durou oito aulas para sua realização, duas aulas a mais do que o planejado inicialmente, pois foi necessário utilizar uma aula para completar a segunda fase da Parte Investigativa, e outra para uma discussão sobre os resultados finais da pesquisa.

Ao todo, participaram da pesquisa 14 alunos separados em quatro grupos, sendo dois grupos com 4 alunos e dois grupos com 3 alunos. Embora a atividade tenha sido aplicada em uma turma relativamente pequena, os resultados foram suficientes para responder às três perguntas de pesquisas indicadas nos objetivos (ver Capítulo 2). 
Os testes iniciais, Teste Inicial de Conteúdo e Teste Inicial de Atitudes, foram realizados na mesma aula. Isto ocorreu logo após a discussão em aula das seguintes perguntas: $O$ que é Estatística? O que ela estuda? e Quais são suas áreas?. Uma semana depois da aplicação dos testes os alunos fizeram a correção, em conjunto com o professor, e tiraram suas dúvidas.

A Parte Investigativa com três fases, Introdução da Tarefa, Desenvolvimento do Trabalho e Discussão Final e Reflexão, foi realizada por meio das Folhas de Atividades (ver Apêndices 1, 2 e 3), ao longo de oito aulas durante um mês. As aulas foram intercaladas na grade horária de Matemática, cuja carga era de quatro aulas semanais.

Foi utilizada uma aula para a aplicação da Folha de Atividade 1, enquanto que para a Folha de Atividade 2, foram necessárias quatro aulas, uma dupla e duas simples. Para a aplicação da Folha de Atividade 3 foram utilizadas três aulas, uma dupla e outra aula simples para uma discussão final sobre os resultados.

Os testes finais, Teste Final de Conteúdo e Teste Final de Atitudes, foram aplicados em uma aula. Eles ocorreram no final do primeiro semestre do ano letivo de 2016, após um intervalo de dois meses do fim de trabalho com as folhas de atividades.

\subsection{Parte Investigativa}

A Parte Investigativa, como já dissemos, foi realizada em oito aulas ao longo de um mês. Neste momento, os alunos já tinham realizado testes iniciais e decidido as variáveis para investigar as características da sua turma. Todas as fases da Parte Investigativa foram feitas em grupos e gravadas em áudio por um de seus integrantes. As gravações foram encaminhadas ao professor/pesquisador.

Para a resolução da Folha de Atividade 1- Introdução da Tarefa, os alunos resolveram as questões já com os grupos formados, mas cada um respondia em sua folha e, caso tivessem alguma dúvida, poderiam discutir com seus colegas de grupo. O objetivo da 
atividade era o desenvolvimento dos conceitos de população e amostra, em conjunto com a experiência inicial dos alunos em uma atividade investigativa.

Antes de mencionar os resultados, vale a pena lembrar que esta atividade foi realizada depois da correção do Teste Inicial de Conteúdo, e que termos como aleatoriedade, população e amostra, já tinham sidos esclarecidos anteriormente. As correções do teste foram realizadas pelos estudantes, sob orientação geral do professor, que devia destacar os critérios utilizados e os erros cometidos.

Nas Questões 1 e 3, referentes aos conceitos de população e amostra, poucos foram os erros cometidos. Dois alunos confundiram os conceitos de amostra, variável e população. Podemos ver uma dessas resoluções na Figura 6.

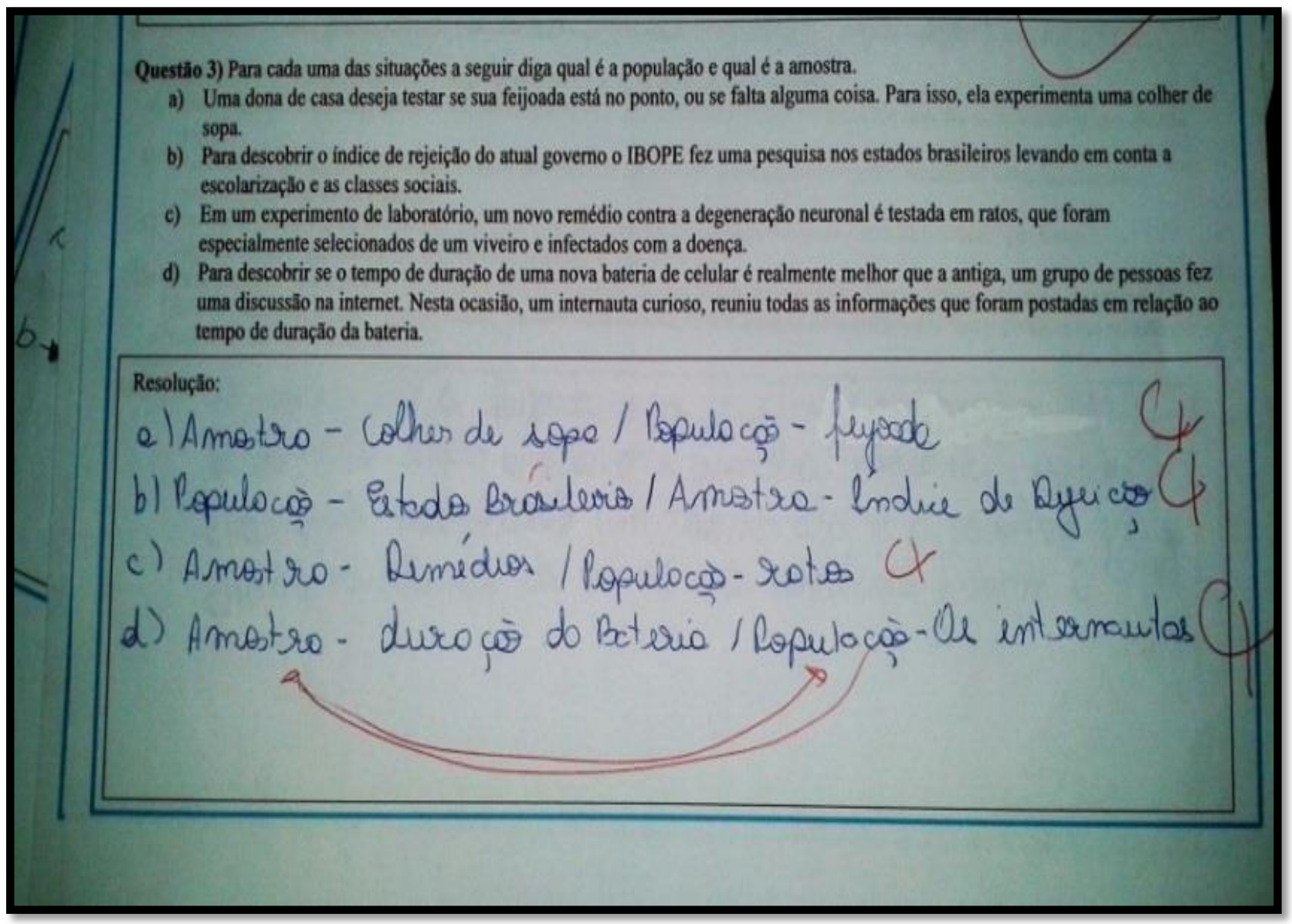

Figura 6: Folha de Atividade 2 - Erro de Conceito. 
Na Questão 2 os alunos tinham que discutir sobre se um evento era aleatório ou determinístico. Para a correção do item é importante avaliar se os argumentos dos estudantes estavam coerentes com as conclusões. Eles deveriam destacar a caracterização da variável e o nível de detalhes da pergunta feita. Por exemplo, o aluno pode falar que o tempo para assistir um jogo de futebol é determinístico, pois sabemos pelas regras que sua duração é de 90 minutos. Mas se a pergunta for, se o jogo começa às $21 \mathrm{~h}$, que horas ele irá terminar? Neste caso, temos mais detalhes da pergunta, e devido aos inúmeros imprevistos que podem ocorrer durante a partida, acréscimos, acidentes, atrasos, não sabemos determinar o tempo exato que o jogo irá se encerrar e, portanto o fenômeno é aleatório. Os alunos deveriam discutir sobre esse tipo de detalhamento das perguntas.

Os alunos foram bem nesta primeira atividade, as notas atribuídas por todos foram MB. O professor recorrigiu as notas posteriormente dos estudantes e quatro notas ficaram com o conceito B, isso devido aos erros cometidos como mostrado nas discussões das questões acima.

Na dinâmica de grupo, que incluía a manipulação dos materiais, os alunos anotaram os dados na Folha de Atividade 2 - Desenvolvimento do Trabalho, e seguiram com as discussões em grupo. O principal objetivo desta fase era o desenvolvimento do processo de investigação dos alunos. A Figura 7 apresenta os alunos fazendo essas atividades em seus grupos.

Cada grupo recebeu um saco para realizar os sorteios contendo as respostas de todos os colegas da turma, que tinha 14 respostas por variável em cada saco. Para realizar o sorteio fizemos uma amostragem com reposição em que os estudantes sorteavam um valor, anotavam na folha e recolocavam no saco.

O problema que tivemos que enfrentar era como justificar o fato de sortear mais valores do que a população (14 alunos). Para explorar melhor as ideias de inferência informal seria necessário um tamanho de amostra superior ao tamanho da população. Para isso, solicitamos a abstração dos alunos para que imaginassem uma população muito maior e controlassem a ansiedade para não olhar todos os dados, pois caso assim fizessem, não teria sentido fazer inferências. 


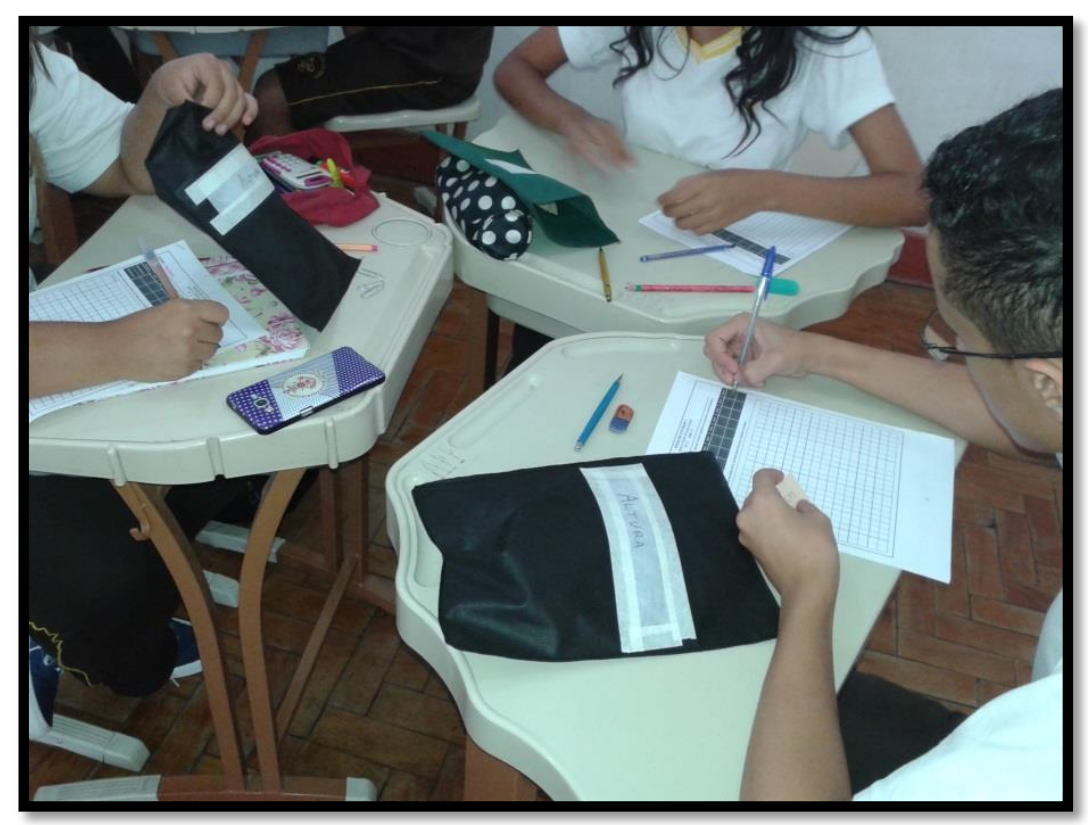

Figura 7: Folha de Atividade 2 - Coleta de Dados

Destacamos que, os grupos puderam escolher as variáveis para trabalhar, de modo que eles ficassem motivados e engajados em desenvolver as atividades. Os grupos ficaram com os seguintes temas:

Grupo 1 - Altura e Cor dos Olhos (3 alunos)

Grupo 2 - Irmãos e Filme - (4 alunos)

Grupo 3 - Sapato e Música - (3 alunos)

Grupo 4 - Internet e Jogo - (4 alunos)

Em relação ao tempo, somente os dois grupos com três alunos ficaram sempre atrasados. A aula "extra" foi devida basicamente a este fato, pois para a organização dos materiais eles tinham um integrante a menos o que dificultou a coleta e a análise dos dados. 
Nesta fase os alunos organizaram, coletaram e analisaram os dados por meio de tabelas e gráficos, sendo incentivados pelo docente a perceberem padrões e tendências que pudessem evidenciar características e informações relevantes da população em estudo. Esta fase demandou o maior tempo da pesquisa utilizando 4 aulas.

Quando trabalhamos com processo de investigação é preciso orientar os alunos para que eles consigam perceber o caminho "mais desejável". O professor deve agir apenas como um orientador e depois de alguns percalços, os estudantes foram capazes de perceber o que deveria ser feito, como ilustrado no trecho abaixo da conversa com um aluno.

\section{“Aluno: Professor, a gente tem que ficar sorteando, mas não pode olhar dentro do saco?}

Professor: Isso, vocês só podem ver um valor sorteado por vez.

Aluno: Entendi, isso é tipo aquelas pesquisas que fazemos e depois vamos estimar quantos tem ao todo?

\section{Professor: Parecido."}

Os registros e conversas de todos os grupos mostram que, apesar de algum esforço, eles não tiveram problemas para trabalhar com a coleta de dados e a organização por meio de tabelas e gráficos. No momento em que montavam os gráficos, juntando todos os dados do grupo, eles percebiam com mais facilidade as tendências das características estudadas da turma e isto auxiliou para compreender melhor os dados.

Por exemplo, no Grupo 1, que estudavam as variáveis "Altura e Cor os Olhos", os integrantes do grupo começaram a organizar a variável altura sem intervalos, anotando cada resultado e sua respectiva frequência. Entretanto, quando eles juntaram todos os dados, viram que isso ficaria inviável para analisar e refizeram as tabelas com os dados agrupados por intervalos. Isto foi interessante, pois não tínhamos discutido previamente com os alunos a organização dos dados em tabelas das variáveis discretas e contínuas.

Outro ponto a destacar foi a comparação em grupo dos dados coletados individualmente. No Grupo 1, teve aluno, que em um primeiro momento, pensou que não 
tinha ninguém com olho preto, mas quando juntaram todos os dados acabou percebendo que isto não era verdade. No Grupo 2, "Irmãos e Filmes", alguns pensaram que não tinha nenhum filho único na sala e depois perceberam que estavam enganados.

Situações como estas apresentadas deram oportunidade aos alunos de vivenciarem na prática as dificuldades da amostragem. Os alunos conseguiram perceber que quando aumentamos as informações das amostras, apesar da variabilidade dos dados aumentarem, as informações expressam melhor a população. Isso foi evidenciado ao responder à última questão, sobre a formulação de uma afirmação de alguma tendência ou padrão dos dados. Nenhum deles utilizou os dados de um único integrante do grupo, mas sim o gráfico e a tabela geral dos resultados.

Os estudantes, nas últimas questões da Folha de Atividade 2, escreveram afirmações de cunho indutivo baseadas em algumas tendências e medidas sobre os dados observados. Contudo, apesar de alguns integrantes do grupo optarem por aspectos mais interessantes para serem analisados, como alguma a média ou a amplitude, o que a maioria dos alunos escolheu foi à medida que eles julgaram ser a mais fácil, como moda, valor máximo ou mínimo.

$\mathrm{Na}$ correção desta atividade, feita pelos estudantes, ninguém atribuiu uma nota inferior ao conceito $\mathrm{B}$ e posteriormente o docente recorrigiu a atividade. Os registros dos alunos mostraram que eles responderam bem à dinâmica da atividade e conseguiram resolver os problemas propostos. Em seguida, os alunos tiveram uma aula sobre as medidas de variabilidade e aprenderam a calcular a variância e o desvio padrão.

Na última fase da Parte Investigativa os alunos resolveram as questões da Folha de Atividade 3 - Discussão e Reflexão Final (ver Apêndice 3). Para a aplicação desta fase o cenário não era o ideal na Escola, pois era momento das festas juninas, trabalhos de outras matérias, feira cultural e exames finais. Isto acabou por atrapalhar alguns alunos e por isso foi necessário uma aula a mais, para que eles resolvessem e analisassem as questões propostas. 
Os grupos ao responderem a Questão 3 da Folha de Atividade 3, teriam que pensar em um critério para dar um intervalo de variabilidade para suas afirmações. Eles não discutiram sobre as diversas possibilidades que poderiam ter para medir a variabilidade dos dados observados. Em vez disso, eles simplesmente transformaram a questão em um problema do tipo "calcule a variância e o desvio padrão".

A Questão 4, de extrapolação da amostra, somente o Grupo 4 - “Internet e Jogos" conseguiu respondê-la com clareza e justificativa razoável, como podemos ver na Figura 8. Nesse grupo eles conseguiram perceber as limitações dos resultados de suas afirmações. Os demais grupos não conseguiram expor com clareza suas justificativas, apesar de também resolverem as questões.

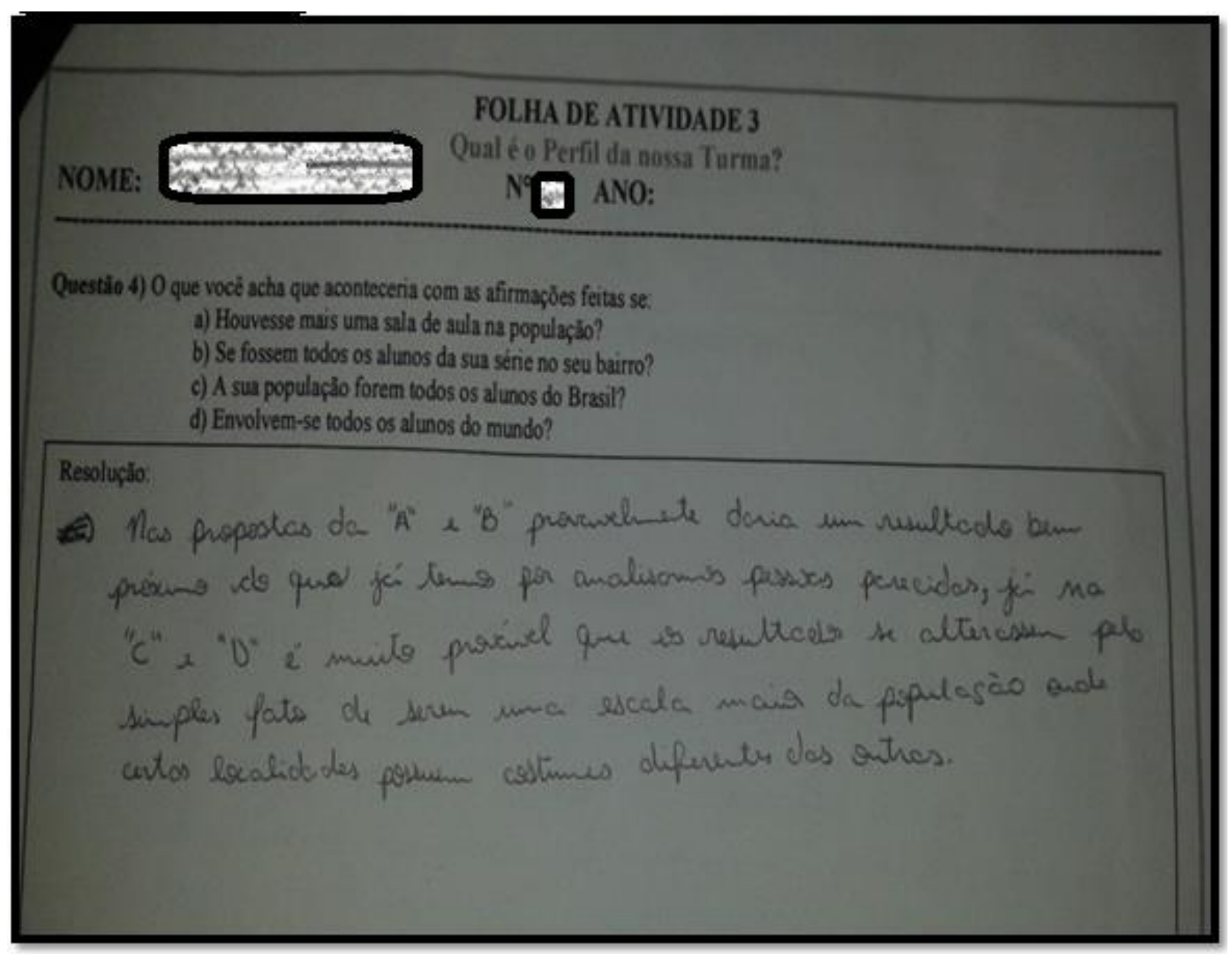

Figura 8: Folha de Atividade 3 - Extrapolação dos Resultados 
Na discussão da Folha de Atividade 3, os alunos conseguiram expor melhor suas ideias e percebemos de fato uma mudança significativa na fala dos mesmos. Como percebemos pelas conversas destacadas abaixo:

"Professor: Pessoal, na última aula, vocês responderam muito sucintamente à última questão. Será mesmo que não podemos dizer nada sobre as suas afirmações em outros contextos?

Aluno 1: Mas professor, não perguntamos nada para ninguém [outras pessoas], como podemos saber?

Professor: Seria realmente necessário? Caso nosso processo de amostragem tenha sido realizado corretamente, não podemos tirar nenhuma conclusão para além da turma de vocês?

....[discussão]...

Aluno 2: Entendi, no теи grupo, eu saberia dizer que a altura dos nossos colegas e no nosso bairro seriam parecidas, mas a dos jovens do Brasil não. Por que [as pessoas] no Nordeste todo mundo é mais baixinho.

Aluno 1: No nosso caso, a Cor dos Olhos de todos os Brasileiros teriam as porcentagens parecidas, mas não do Mundo.

....[discussão]...

Aluno 3: A nossa média de horas[uso de horas diárias na Internet] ficou baixa e talvez isso seja uma característica da nossa turma.

Aluno 4: Conheço pessoas que passam o dia inteiro conectadas na Internet.

Aluno 3: Mas considerando a moda das horas e o desvio padrão, talvez nossa afirmação se aplique aos outros[colegas da Escola], pelo menos. 
....[discussão]...

Aluno 5: Professor, como podemos ter certeza de que as outras pessoas seguem esses padrões[da turma analisada]?

Professor: Ai que está o problema. Nós nunca teremos certeza. Apesar disso, caso nossos dados tenha sido analisados e coletados corretamente, podemos tirar boas conclusões sobre a população inteira a partir de uma amostra."

Convém observar que, um dos grupos com 4 alunos já tinha terminado a Folha 2 e pediram para adiantar o começo da Folha 3. O que deve ser ressaltado, é que mesmo sem conhecer os cálculos sobre as medidas de variabilidade, algo que seria trabalhado posteriormente com os estudantes, eles foram mais criteriosos ao pensar no intervalo de variabilidade que poderiam dar às afirmações feitas pelo grupo.

No caso, para o Grupo 4, a ideia de fazer um desvio surgiu naturalmente, não em relação à média, mas em comparação das amostras do grupo. Entretanto, depois que eles viram os conceitos de variância e desvio padrão, assim como os demais estudantes, simplesmente calcularam essas medidas e continuaram com as questões, como podemos ver na Figura 9.

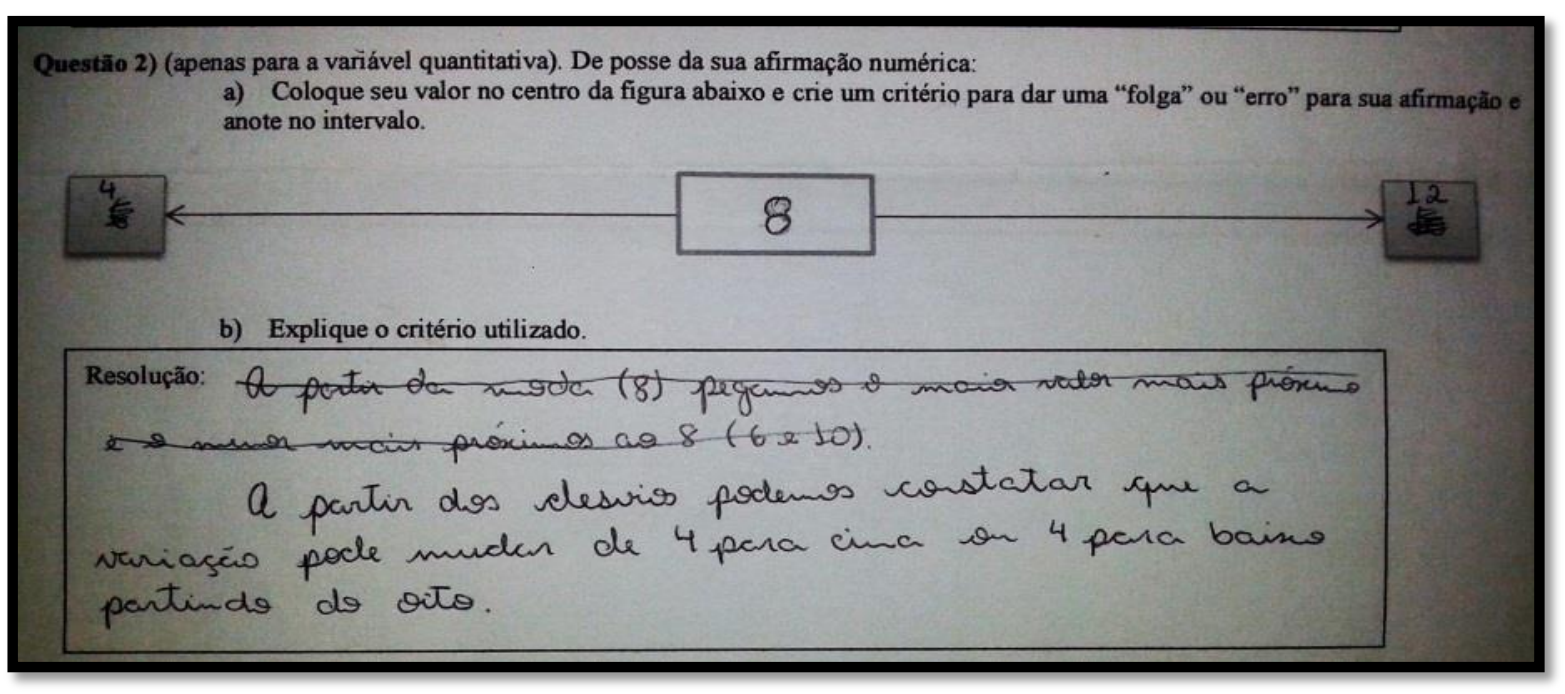

Figura 9: Folha de Atividade 3 - Critério de Variabilidade 


\section{2 - Testes de Atitudes}

Nos testes de atitudes (Apêndices 4 e 5), os alunos utilizaram pseudônimos para responder e atribuíram notas entre 0 e 5 para as questões formuladas. Assim, eles teriam mais liberdade para atribuir a nota que desejassem, sem o temor de expor suas opiniões.

Para analisar o resultado dos testes, primeiramente separaremos as 12 perguntas em dois grupos. O primeiro grupo será composto por questões com características positivas em relação à Estatística, isto é, quanto mais alta a nota, melhor é a sua opinião sobre Estatística. O segundo grupo será composto por questões com características negativas, isto é, quanto menor a nota do aluno, melhor sua atitude em relação à Estatística.

Analisaremos as perguntas em três segmentos. O primeiro segmento será para verificar a evolução dos estudantes, antes (Teste Inicial de Atitudes) e depois (Teste Final de Atitudes), em cada uma das perguntas respondidas. Para isso utilizaremos gráficos de colunas, incluindo a média e o desvio padrão das respostas. No segundo segmento, olharemos para dois grupos de perguntas, as que indicam atitudes positivas e as que indicam atitudes negativas. Já para o terceiro segmento transformaremos o escore para as questões negativas, da seguinte forma: "0 vira 5", "1 vira 4", "2 vira 3", "3 vira 4", "4 vira 1" e "5 vira 0". Deste modo, podemos analisá-las como questões "positivas" e montar um panorama geral dos resultados. O leitor pode verificar a lista de pontuação no Apêndice 11.

A redação e o tempo verbal das perguntas no teste antes e depois é importante, pois dependendo da maneira como são feitas as perguntas, os resultados podem ser ambíguos. No nosso caso, por falha de redação, optamos por excluir da análise a seguinte pergunta: “Eu planejo estudar muito nas atividades de Estatística (antes) - Eu vou estudar muito nas atividades de Estatística (depois)”. Percebemos ao iniciar a análise que não ficou claro se os alunos deveriam responder tendo em vista a atividade que foi aplicada ou em relação às atividades futuras em Estatística. 
Não se observou ambiguidades nas outras perguntas e foram feitas apenas adequações do tempo verbal. O leitor pode consultar as redações dos testes nos Apêndices 4 e 5 .

As questões que fazem parte do Grupo Positivas, na redação do Teste Inicial de Atitudes, são: "Eu irei gostar de Estatística"; "Eu uso Estatística no meu cotidiano"; "Eu posso aprender Estatística"; "Eu estou interessado em entender as informações Estatísticas", "Eu estou interessado em usar Estatística" e "As pessoas usam um novo jeito de pensar para estudar Estatística".

As questões no Grupo Negativas, na redação do Teste Inicial de Atitudes, são: “As Estatística são raramente presentes na vida real"; "Estatística é uma matéria difícil”; "Eu me sentirei inseguro quando estiver estudando problemas de Estatística"; "Estatística é irrelevante para minha vida"; "Eu vou achar muito difícil compreender os conceitos de Estatística" e "Eu fico assustado com Estatística".

Mostraremos na sequência os principais resultados na análise pontual por perguntas, os resultados completos podem ser vistos no Apêndice 12. Em seguida, descreveremos a análise pelos grupos de perguntas e, por fim, faremos uma avaliação em conjunto de todas as questões.

\section{Análise pontual das perguntas.}

Antes de começarmos a análise das perguntas, relembramos que os alunos antes de responderem o Teste Inicial de Atitudes já tinham feito uma introdução inicial aos conceitos de Estatística.

Destacamos abaixo algumas conclusões:

- Os estudantes atribuíram tiveram uma média alta na questão sobre os alunos aprenderem Estatística, tanto antes quanto depois da aplicação da atividade, o que evidencia, na opinião dos estudantes, que eles foram capazes de aprender Estatística.

- Sobre a dificuldade em compreender os conceitos de Estatística, os alunos aumentaram um ponto depois da atividade, demonstrando que eles sentiram 
um pouco mais de dificuldade de entender os conteúdos que foram trabalhados.

- Após a atividade, na questão relativa à Estatística estar raramente presente na vida real, três alunos diminuíram cinco pontos de seus escores, o que nos leva a concluir, que para estes estudantes, a atividade teve um impacto bem positivo.

- Casos pontuais de alunos que chamaram atenção: O aluno Kian L atribuiu nota zero depois da aplicação da atividade na questão sobre o uso da Estatística no seu cotidiano. O aluno Jucrécio, mudou de 5 pontos para 0 no item sobre a Estatística não ser relevante para a vida das pessoas.

Obtemos assim, notas maiores que três pontos dos alunos nas questões positivas no Teste Inicial de Atitudes, as quais foram mantidas depois, no Teste Final de Atitudes.

\section{1- Análise dos grupos de perguntas.}

Para esta análise, consideramos dois grupos de perguntas, o Grupo Positivas, (perguntas de 1 a 6), e o Grupo Negativas, (perguntas de 7 a 12). Para cada estudante, realizamos a análise descritiva dos resultados, com base na média de notas relativas de cada grupo.

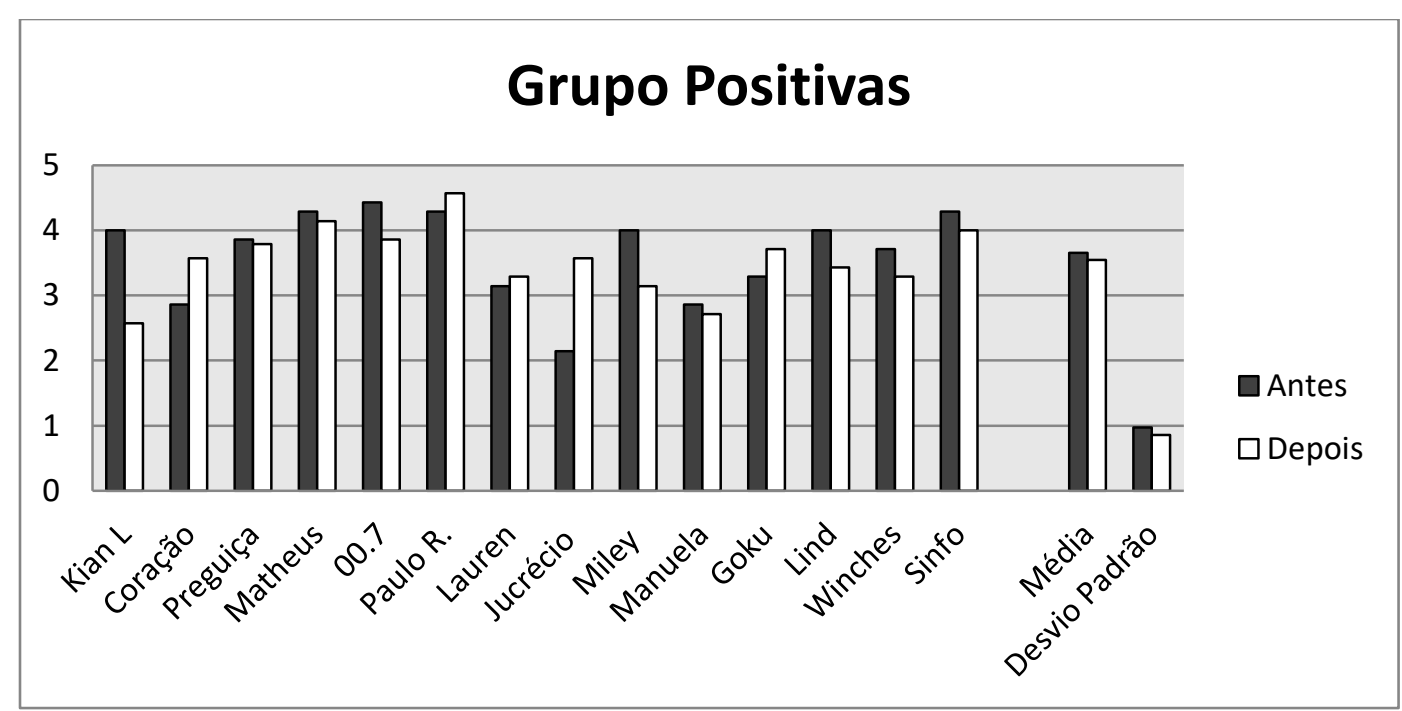

Figura 10: Teste de Atitudes - Grupo das perguntas Positivas

Podemos perceber pelos dados que poucos alunos mudaram suas atitudes em relação ao teste inicial, considerando a variabilidade. $\mathrm{O}$ desvio padrão baixo nos dois 
casos, antes e depois, evidencia que os dados tiveram pouca variação. Apesar disso, 9 alunos acabaram abaixando um pouco sua média geral de notas depois da atividade, o que nos mostra um efeito um pouco negativo em relação às atitudes positivas dos alunos.

Ainda assim eles mantiveram médias gerais altas das notas, antes e depois do teste, o que nos mostra que a dinâmica apresentada foi capaz, de conservar as boas impressões que os alunos tinham sobre a atividade antes de iniciar a atividade.

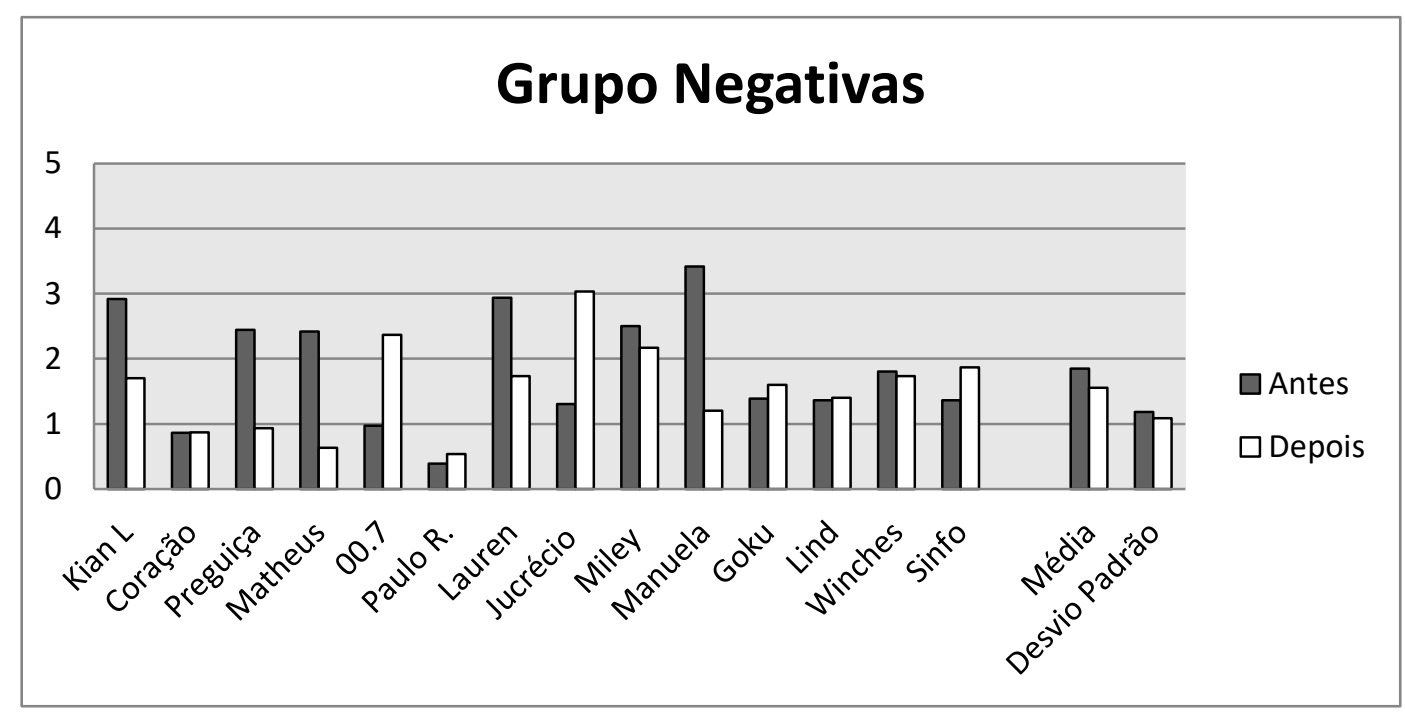

Figura 11: Teste de Atitudes - Grupo de perguntas Negativas

Podemos perceber uma diferença maior em relação ao Grupo Positivas. Dos 14 alunos, 6 alunos ficaram com médias gerais muito próxima antes e depois dos testes, mas 5 alunos baixaram e 3 alunos subiram sua média. Consideramos assim um pequeno impacto para alguns alunos, que passaram a ter uma melhora em relação às atitudes negativas que eles tinham antes da atividade.

\section{2- Análise do Grupo Geral de perguntas.}

Para esta análise, utilizaremos um escore para trocar as respostas das questões com características negativas e, assim, analisar e manter em conjunto todos os dados. Feito isso, tiraremos uma média e retomaremos o processo de análise como feito anteriormente. 


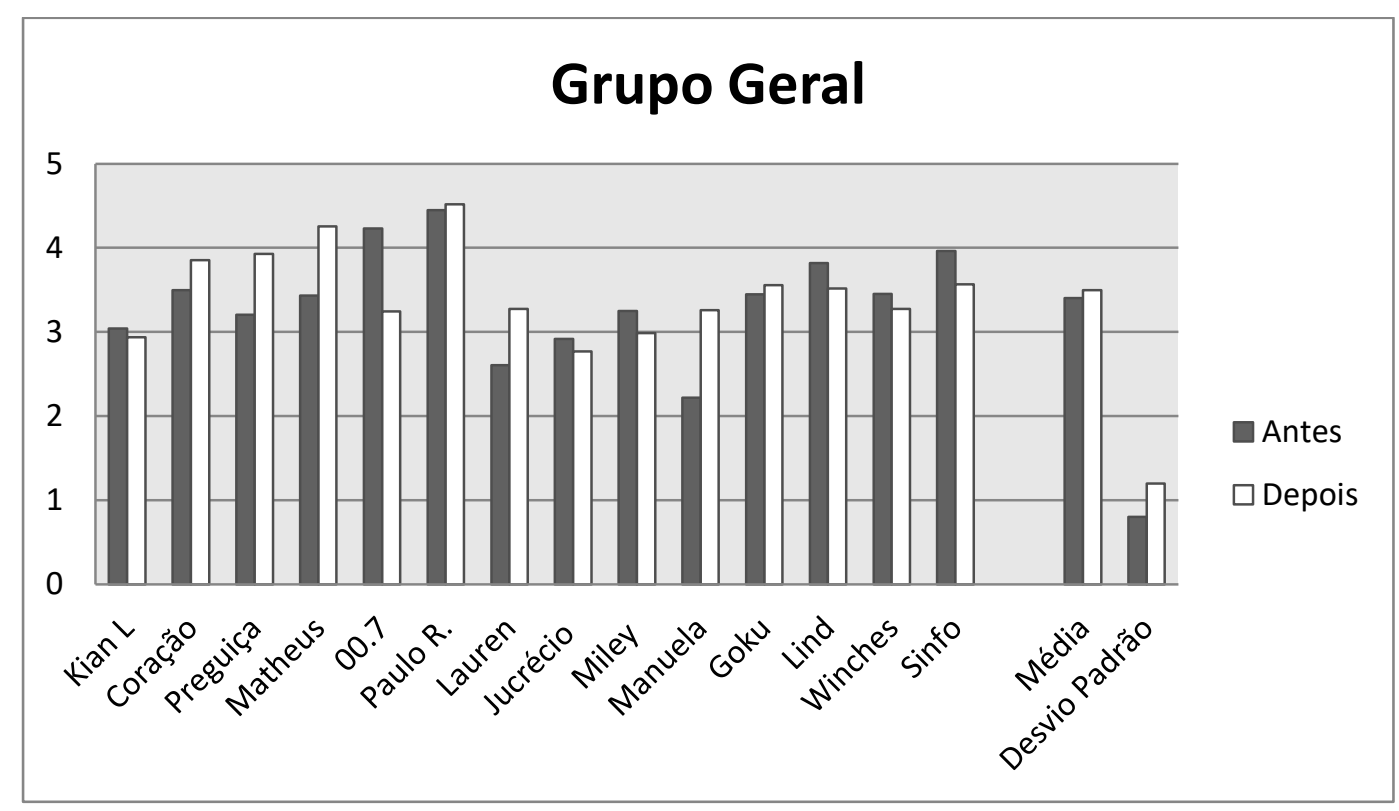

Figura 12: Teste de Atitudes - Grupo Geral das Perguntas

A média geral depois da atividade aumentou um pouco, entretanto não houve uma mudança significativa. Dos 14 alunos, percebemos um aumento nas notas médias em 5 estudantes, ou seja, o que evidencia uma perspectiva um tanto melhor nas atitudes.

O impacto foi maior em relação ao Grupo Negativas do que o Grupo Positivas, o que nos mostra que os estudantes mudaram mais suas atitudes com características negativas. Concluímos assim, que as atividades propostas se mostraram importantes para manter as atitudes positivas, em relação ao Teste Inicial de Atitudes, que já tinham boa perspectiva antes dos testes.

\section{3 - Testes de Conteúdos}

O Teste Inicial de Conteúdo (ver Apêndice 6) foi respondido individualmente pelos alunos. De modo geral, como eles estavam estudando conteúdos básicos de Estatística Descritiva antes do teste, os estudantes não tiveram grandes dificuldades para responder às questões. Relembramos que os alunos, antes mesmo de iniciar as atividades, tiveram uma breve introdução de Estatística sobre seu campo de atuação, gráficos, tabelas e medidas de tendência central. 
A maioria dos erros apresentados no teste se concentrou em conceitos sobre regra de três e cálculos com números decimais. Entretanto, não foram observados erros graves com a resolução das questões, apenas falta de atenção em alguns pontos que serão destacados em seguida. Sobre as questões de Estatística, a maioria dos alunos acertou todas as questões.

Alguns alunos erraram a Questão 2, que envolvia um raciocínio mais apurado sobre juros e porcentagem. Eles acabaram por cometer um erro comum, de não considerar que o custo inicial do produto seria $100 \%$.

Na Questão 4, sobre a organização de dados, os alunos teriam que usar as informações da tabela de frequência para montar um gráfico de barras. Eles se confundiram na hora de relacionar as variáveis no plano cartesiano e no eixo das abcissas, como podemos ver na Figura 13.

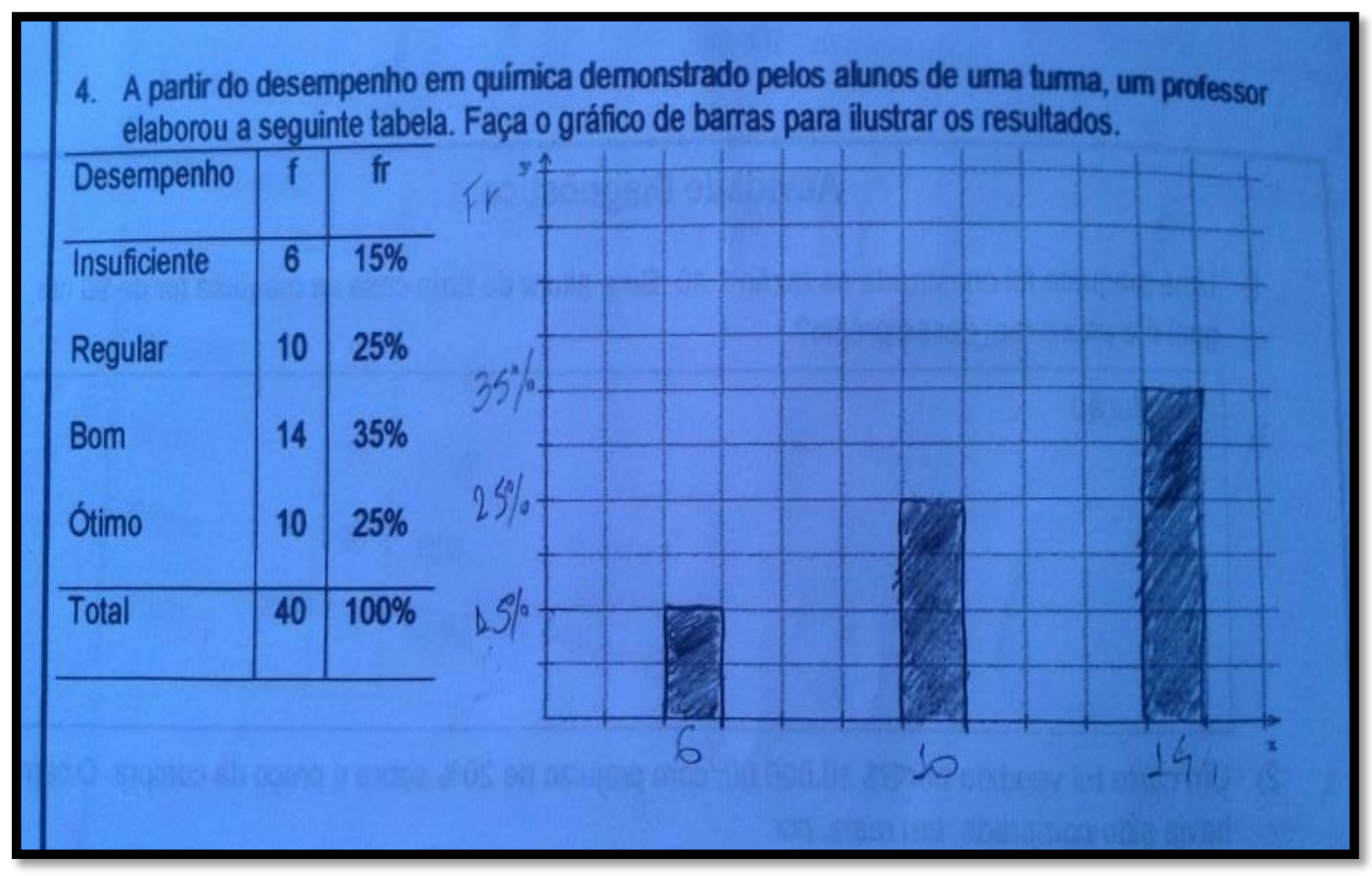

Figura 13: Teste Inicial de Conteúdo - Erro no plano cartesiano

Na Questão 5, para relacionar colunas e os respectivos conceitos de estatística, alguns alunos confundiram cada valor observado com o conceito de amostra e parte da população observada com os dados. Podemos ver esse erro destacado na Figura 14. 


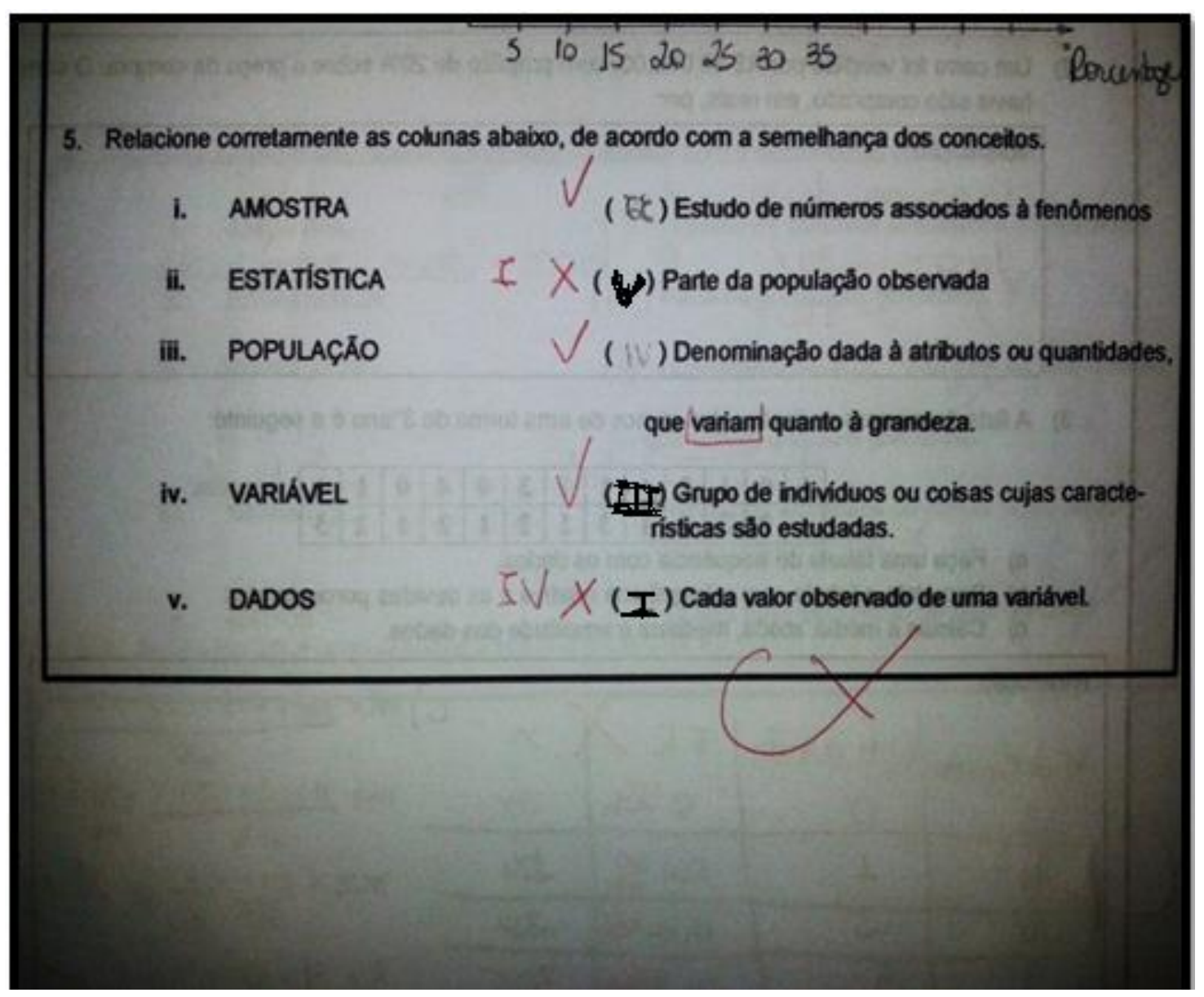

Figura 14: Teste Inicial de Conteúdo - Exemplo de erro.

Nem sempre é clara a diferença entre os conceitos de dados, amostra e variável. Os erros destacados acima foram cometidos por poucos alunos. Na Figura 15 temos um exemplo do acerto das questões discutidas anteriormente. 


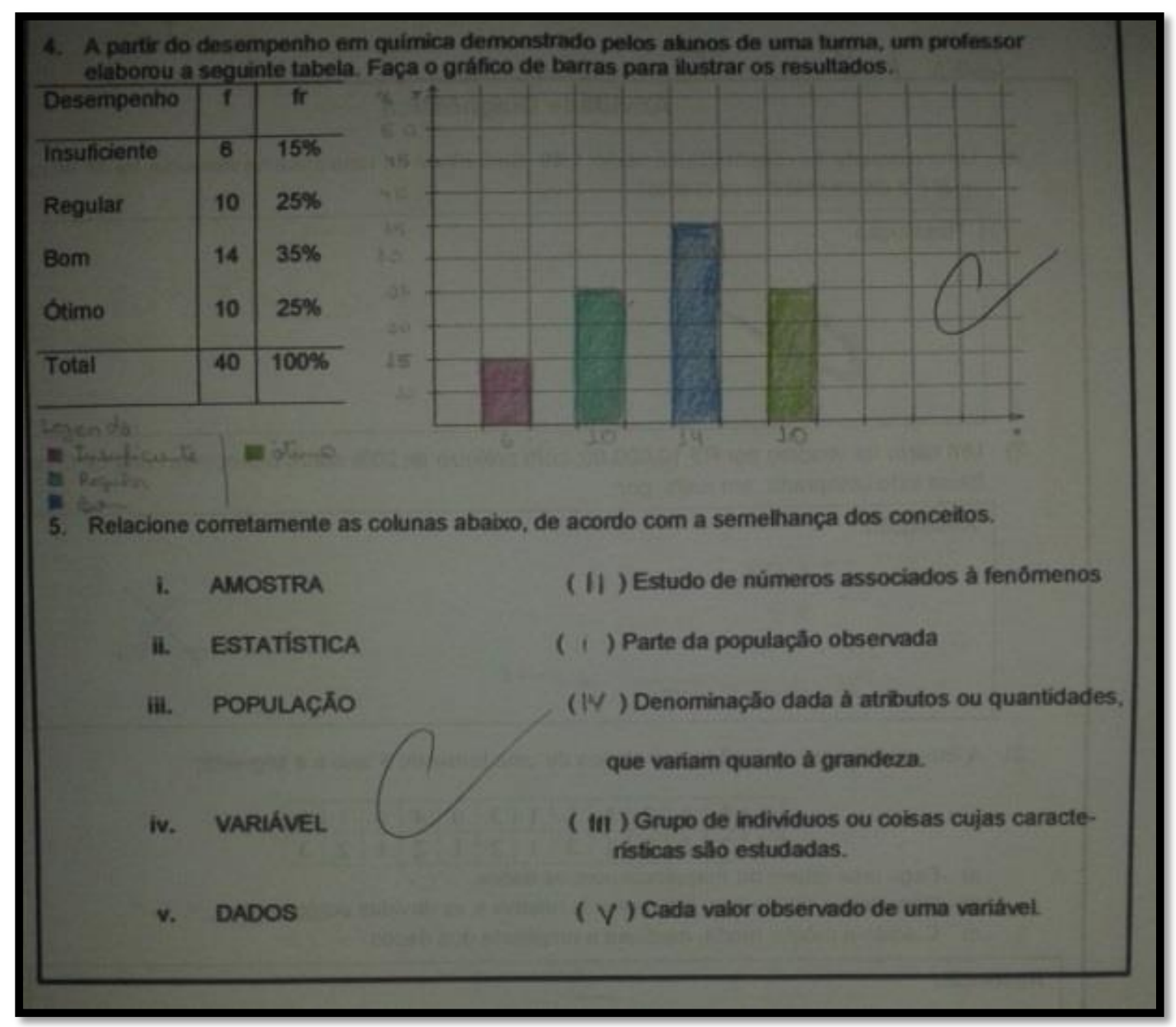

Figura 15: Teste Inicial de Conteúdo - Questões 4 e 5

Depois da aplicação do teste inicial, os próprios alunos corrigiram e atribuíram um conceito ao teste, com a seguinte escala: MB (Muito Bom), B (Bom), R (Regular) e I (Insatisfatório). Segue, na Figura 16, um gráfico de barras com os resultados das notas atribuídas pelos próprios alunos. Podemos ver que não teve nenhuma nota $\mathrm{MB}$, entretanto, as notas foram boas em sua maioria. Apenas um aluno atribuiu à nota $\mathrm{I}$, apesar de ter acertado um pouco mais de $50 \%$ do teste. Após a correção dos exercícios, não houve necessidade de nenhum trabalho de apoio complementar para continuar com a pesquisa. 


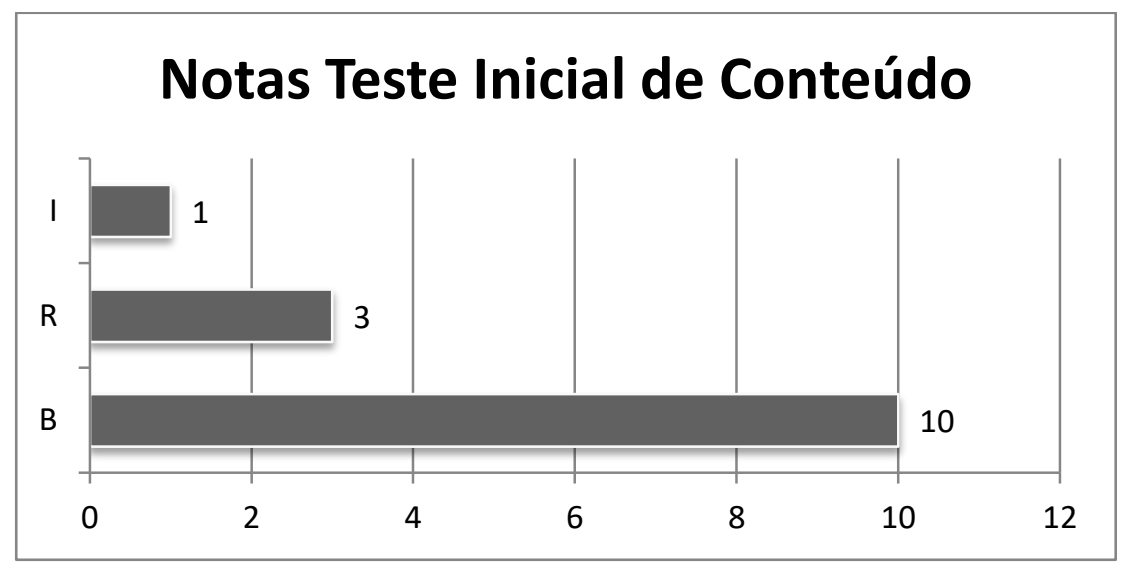

Figura 16: Notas do Teste Inicial de Conteúdo

O Teste Final de Conteúdo (ver Apêndice 7), que ocorreu um mês depois da última correção da Folha de Atividade 3, foi aplicado como um "teste surpresa" e os alunos tiveram apenas uma aula simples para resolvê-lo.

Nas questões Questão 1 e 4, os alunos tinham que verificar alguma tendência dos dados calculando as medidas de tendência central e de variabilidade, mas isso não ocorreu. Eles fizeram todos os cálculos corretos, porém sua análise e justificativas não foram claras, pois os argumentos foram superficiais e as conclusões inadequadas.

O erro na Questão 1, ver Figura 17, foi de organização dos dados, pois os dados já estavam organizados em forma crescente $(2,4,7,10,10,10,12,12,14$ e 15), o que fez os estudantes pensarem que os dados continuariam crescendo, e indicaram que os valores continuariam crescendo, como $(13,14,20)$ e não algo próximo de 10. 


\section{Teste de Conteúdo}

1) Alguns vendedores de carros da marca $X$ foram selecionados, no último mês, e anotou-se 0 número de vendas. Os resultados, em ordem crescente, foram: $2,4,7,10,10,10,12,12,14,15$.

Determine: (a) população em estudo, (b) amostra, (c) média, (d) mediana, (e) moda, (f) Dê um palpite sobre as vendas dos carros da marca $X$ no próximo mês? Justifique.

\section{RESOLUÇÃO

$$
24,7,10,10,10,12,12,14,15
$$

a) Populogar ivendas

$+2$

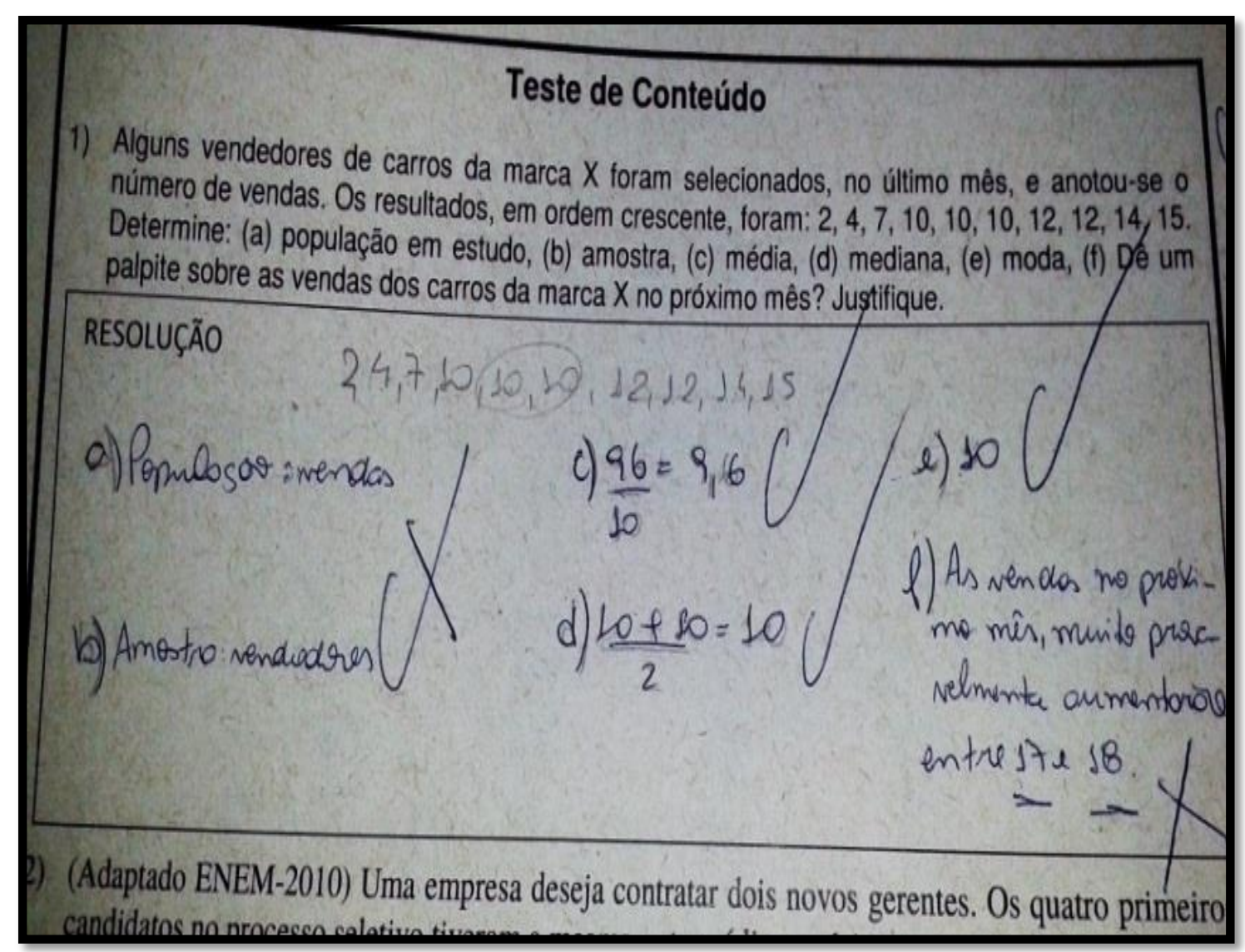$$
\text { c) } \frac{96}{10}=9,60
$$$$
\text { d) } \frac{10+10}{2}=10
$$

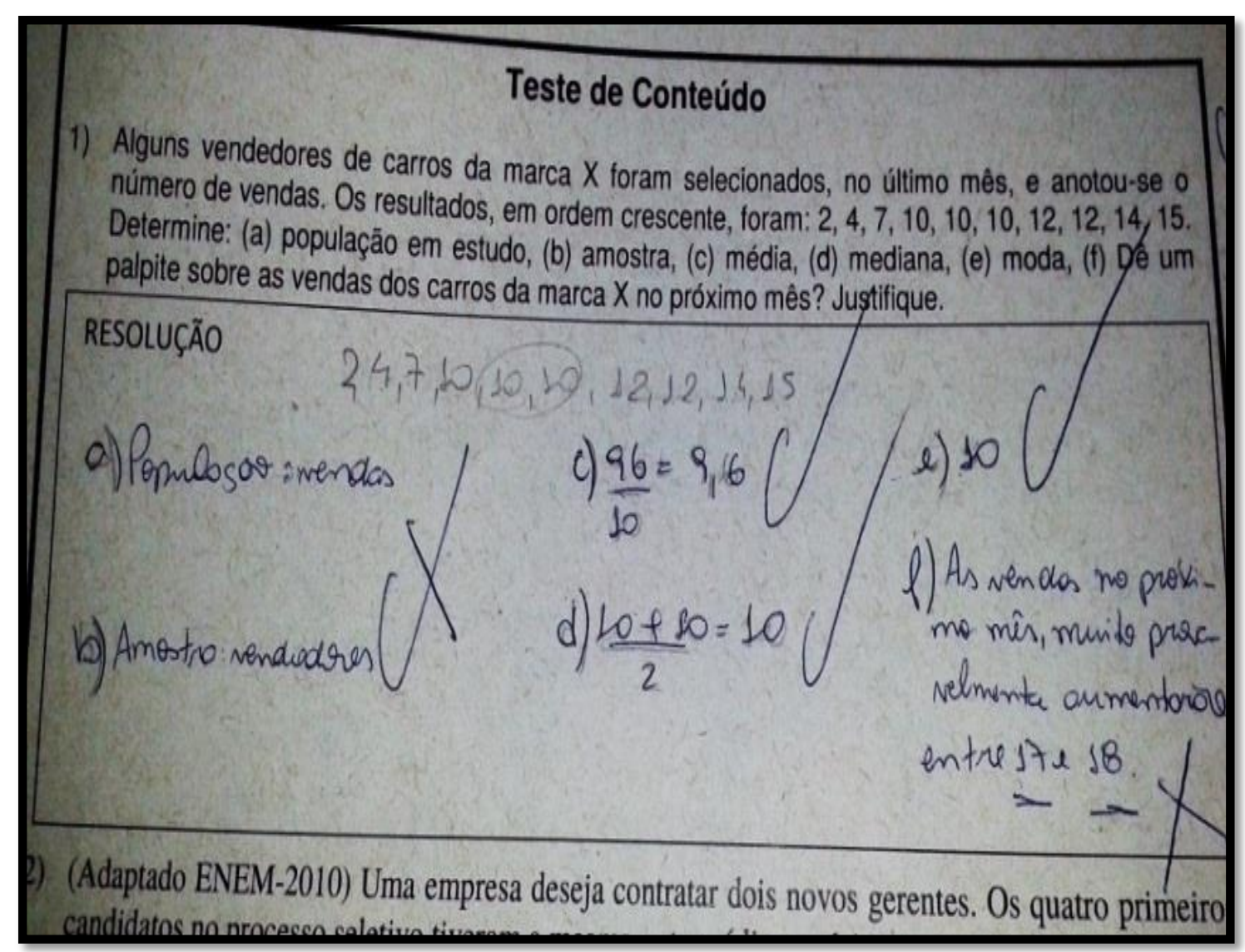

Figura 17: Teste Final de Conteúdo - Erro de análise

Na Questão 4, o erro foi parecido, mas nesse caso os alunos precisavam justificar se um fabricante era honesto ou não, com a única informação de que ele afirmava que a média de duração das lâmpadas era de 4200 horas e uma amostra de 10 lâmpadas lhe forneceu a média de 4000 horas. A expectativa era dos alunos citarem as medidas de variabilidade para justificar em suas afirmações, mas isso poucas vezes foi feito. Apenas alguns alunos citaram "depende do desvio padrão" ou "da margem de erro".

Salvo os erros sobre uma análise mais refinada dos resultados, em relação aos demais itens e questões, praticamente, não houve mais problemas. Lembramos que a dificuldade dos itens do Teste Final de Conteúdo foi alterada e, nesta ocasião, eles precisavam fazer argumentação e justificativa mais apuradas sobre os problemas.

Na Figura 18 temos um exemplo de uma questão que foi adaptada do ENEM em que os estudantes demonstram terem conseguido compreender o conceito do desvio padrão e não fazer apenas os cálculos. 


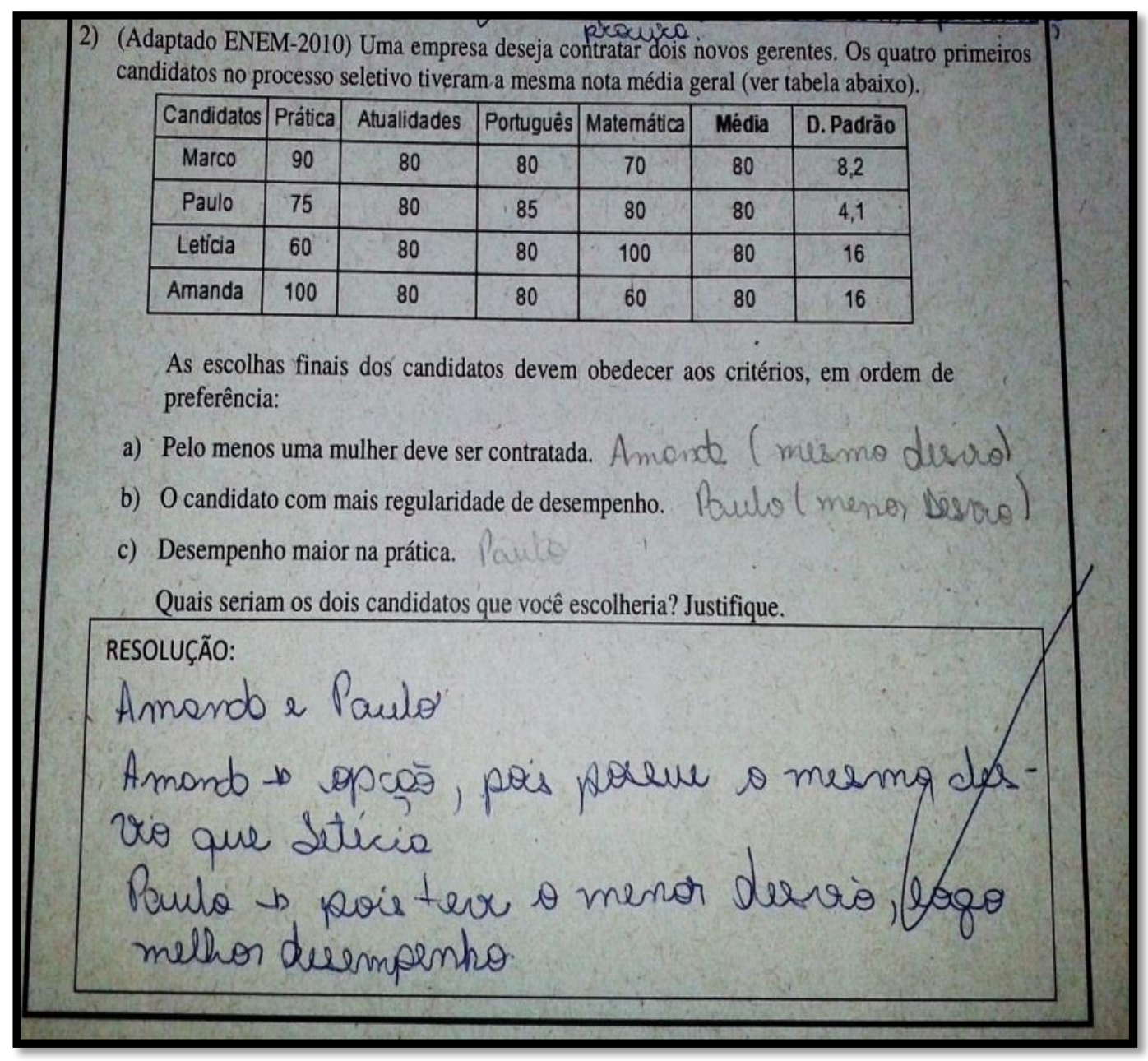

Figura 18: Teste Final de Conteúdo - Adaptação do ENEM

O Teste Final de Conteúdo foi o professor quem corrigiu e as notas ficaram entre 5 e 9 em uma escala de 0 até 10 pontos. Os alunos que obtiveram as menores notas, cometeram os dois erros mostrados acima.

Depois disso, foi feita uma discussão com todos os alunos, sobre a pesquisa em geral, e em seus comentários conseguimos perceber uma mudança no vocabulário sobre os conceitos de "amostra e população".

$\mathrm{Na}$ discussão com os alunos eles demonstraram terem gostado bastante das atividades e acharam que a metodologia de investigação foi algo novo e interessante. Pelos resultados mostrados, podemos inferir que foram suficientes para desenvolver os conceitos 
iniciais de Estatística, pois os estudantes compreenderam além dos cálculos o significado dos conteúdos e isso, se deve em parte, ao método utilizado.

\subsection{Análise Geral}

Ao longo da pesquisa pudemos destacar alguns fatos na análise pontual dos dados, mas é quando olhamos para o geral que percebemos as relações mais interessantes e que nos possibilitam responder às questões propostas em nosso objetivo (ver Capítulo 2). Destacaremos aqui alguns aspectos da pesquisa, bem como as sugestões para aplicações futuras.

Os alunos conseguiram desenvolver afirmações de cunho indutivo depois da aplicação da Folha de Atividade 2. Nessa atividade o processo de investigar, manipular e analisar os dados por meio da dinâmica em sala de aula incentivou os estudantes a buscarem reflexões sobre as tendências e padrões dos dados coletados.

Em relação aos conteúdos, os alunos não apresentaram dificuldades para aprendêlos, e se apropriaram bem dos conceitos e da linguagem probabilística. Pudemos perceber isso, pela maneira como foram respondidos os problemas propostos, nas folhas de atividades e nos áudios das conversas dos grupos, que foram destacados no item 4.1.

Apesar do Teste de Atitudes ter mostrado, no geral, uma mudança pouco significativa, pudemos ver por meio dele que os estudantes que não tinham vontade de estudar aquele conteúdo, e que depois das atividades, acabaram por demonstrar interesse pela Estatística. Portanto, podemos considerar que a proposta apresentada foi capaz de mudar as atitudes dos alunos em relação às características negativas que eles tinham antes da atividade.

Em um ambiente de investigação o aluno sai da sua zona de conforto e é incentivado para trabalhar em um problema. Isso induziu alguns alunos a acharem este processo muito difícil, que foi refletido no Teste de Atitudes. Apesar disso, eles se saíram melhor no Teste Final de Conteúdo em relação às questões que eles responderam no início da atividade. 
Propostas para a sala de aula que trabalham com um ambiente de investigação são raras no ensino de Matemática na Escola Básica. Dessa forma, os alunos encontraram dificuldades com a organização dos grupos e, também, para responderem os problemas propostos. Isto foi percebido ao longo das fases iniciais da investigação e registrado pelas gravações. Mesmo assim, quando os estudantes se acostumaram com a sequência didática, eles acabaram por demonstrar interesse, sendo mais ativos em suas participações, relacionamentos com os colegas e organização melhor de seu conhecimento para responder os problemas propostos.

$\mathrm{Na}$ discussão final feita com os alunos percebemos que os estudantes entenderam os conceitos de amostra e população, pois eles mostraram por meio de suas falas e dos Testes de Conteúdo terem compreendido as limitações de uma amostra e sobre os processos aleatórios que podem existir na hora de tirar algumas conclusões dos dados. Ou seja, mesmo que as fases de investigação sejam um processo trabalhoso, elas são capazes de despertar interesse nos alunos e produzir o aprendizado com significado.

Importante destacar que, posteriormente à realização da Folha de Atividade 3, os alunos tiveram a oportunidade de por em prática o aprendizado em Estatística. Para completar a verba para a formatura, foi sugerido para eles fazerem nas sextas-feiras a venda de doces e salgados no intervalo para arrecadar fundos. E assim, naturalmente surgiram perguntas do tipo: Como descobrir qual seria o melhor preço? Quais doces ou salgados iriam vender? Esses questionamentos os fizeram retomar o que tínhamos visto até o momento e ainda complementar o aprendizado, aplicando outros conhecimentos da Estatística.

Como destacado no comentário da resolução da Questão 4, na Folha de Atividade 3, não consideramos que é necessário o trabalho prévio com os alunos em medidas de variabilidade para eles criarem os critérios dos intervalos de variabilidade das suas afirmações. A própria atividade se mostrou capaz de despertar o interesse por esse assunto nos alunos sem confundi-los e talvez possa ser utilizada como um fator motivador para o aprendizado das medidas de variabilidade. 
O tempo para a atividade se mostrou um fator importante para a aplicação da Parte Investigativa. Consideramos assim que o professor poderia, dependendo da sua turma, ter mudado alguns aspectos, como a introdução sobre a discussão inicial de população e amostro ou parte do processo investigativo da Folha de Atividade 2, caso os alunos já saibam calcular, organizar e entender os dados utilizando gráficos e tabela. $\mathrm{O}$ trabalho poderia ser reduzido utilizando um banco de dados e um computador. Tudo isso visando diminuir a quantidade de aulas. Também, caso o docente queira trabalhar apenas com as ideias da inferência informal, pode ir diretamente para a Folha de Atividade 3. 


\section{Capítulo 4}

\section{Conclusão}

A Estatística também possui conteúdos tão importantes como os da própria Matemática. Durante as atividades que realizamos, tentamos ao máximo mostrar esse novo campo de trabalho aos estudantes por meio de uma forma diferente, das aulas tradicionais, e que possa despertar interesse do aluno. Quando o discente manipula seus próprios dados reais e investiga-os para descobrir algo novo sobre sua própria turma, isso o coloca como o principal agente do desenvolvimento de suas competências e o estimula a cada vez aprender mais.

Motivação, uma palavra chave para se ter bons resultados numa sala aula. Quando trazemos temas que estão relacionados ao cotidiano dos alunos, as aulas ficam mais interessantes e, consequentemente, seu aprendizado se torna mais efetivo. No momento em que os alunos selecionavam as variáveis para investigar as características de sua turma, os estudantes demonstraram um envolvimento com a proposta. Dessa forma conseguiu-se reter suas atenções e incentivá-los a pesquisar, analisar e investigar seus próprios dados em busca de informações relevantes.

Conseguimos articular, por meio desta pesquisa, as fases de investigação de Crhistiansen e Walther (1986) e os princípios de Makar e Rubin (2009) para desenvolver uma atividade estruturada visando o aprendizado dos conceitos de Estatística. Podemos perceber que o aprendizado dos estudantes sobre realizar inferências informais foi se concretizando a cada folha de atividade e, ao final da sequência didática, os alunos avançaram no desenvolvimento de uma linguagem técnica incluindo avanços no conhecimento sobre aleatoriedade, população e amostra, e a variabilidade dos dados. 
Com relação às perguntas de pesquisa, Pergunta 1: Podemos estimular os alunos, partindo da Inferência Estatística Informal e dentro de uma aula de investigação, a desenvolver afirmações de cunho indutivo?, podemos perceber por meio das gravações na discussão final da Folha de Atividade 3 e nas resoluções do Teste Final de Conteúdo que os alunos conseguiram desenvolver algumas afirmações de cunho indutivo, sempre quando estimulados, a analisarem os dados para além dos cálculos que estavam sendo realizados. Planos de aulas que deixam os alunos livres para pensar, argumentar e investigar são escassos nas escolas de São Paulo e propostas como a idealizada pela pesquisa se mostrou eficiente para o aprendizado com significado dos estudantes.

Para responder à Pergunta 2: Por meio de um experimento de inferência informal em sala de aula, os alunos conseguiram desenvolver atitudes positivas em relação à Estatística? utilizamos uma adaptação da pesquisa de atitudes do grupo SATS-36 (2005). Os Testes de Atitudes verificaram que os alunos compreenderam que a Estatística é uma ciência que utiliza uma nova forma de pensar, e que não se sentiram assustados para estudá-la, ou acharam que a matéria seria algo difícil para seu aprendizado. $\mathrm{Na}$ análise geral do teste percebemos um pequeno impacto na média geral dos resultados e que os alunos melhoraram suas atitudes com características negativas.

A Pergunta 3: Os estudantes conseguiram compreender os significados básicos da Inferência Estatística Informal? Consideramos como aspectos básicos da inferência informal a compreensão dos estudantes sobre os conceitos de população, amostras e variáveis, o que foi evidenciado por meio da resolução das Folhas de Atividades 1 e 2 e na discussão final da Folha de Atividade 3.

O tempo para a aplicação da sequência didática foi de oito aulas ao longo de dois meses, que podem ser distribuídas em conjunto com a carga de aula semanal de Matemática. Os materiais utilizados durante as atividades são de fácil acesso a todos. Portanto, a dinâmica se mostrou capaz de ser realizada e não atrapalha o planejamento semestral do docente.

Em propostas futuras o professor, dependendo da sua turma, pode modificar os objetivos das atividades e encurtar alguma tarefa das três folhas de atividades. Também 
parece que, para que os estudantes consigam chegar às ideias de variabilidade, não há a necessidade de o professor apresentar previamente as medidas de variabilidade mais sofisticadas. Os estudantes parecem que podem evoluir sem grandes dificuldades para a obtenção de alguma forma de medir a variabilidade dos dados. Nesse sentido o uso de medidas como amplitude ou intervalo interquartil poderia estimular a ideia sobre tomar algum desvio dos dados, que surge naturalmente no critério para elaborar alguma margem de erro nos resultados apresentados.

A situação atual do ensino de Matemática no Brasil não é das melhores. No ano de 2016 ocupamos a $133^{\circ}$ posição de 139 países no ranking publicado pelo Fórum Econômico Mundial. O ensino de Estatística ainda aparece tímido nas Escolas, mesmo depois dos Parâmetros Curriculares Nacionais, Brasil-MEC (1997) indicarem que a disciplina deve ser trabalhada desde o Ensino Fundamental II. Pouco vemos isso acontecendo em sala de aula, quase 20 anos depois.

Os Parâmetros Curriculares para o Ensino Médio, Brasil-MEC (2002) apontam que uma das competências básicas para ser trabalhada na área de Ciências Exatas é Investigar e Compreender. Infelizmente, isso é o que menos podemos ver no ambiente escolar.

A Proposta apresentada nesta dissertação, que busca colaborar positivamente para este cenário, com uma dinâmica interessante para ser trabalhada com os estudantes, que lhes motive e cause interesse, e que seja útil e de fácil acesso ao docente, pode contribuir na direção desejada de melhoria do aprendizado de conceitos de Estatística pelos estudantes. 


\section{Referências}

Batanero, C. (2001) Didáctica de la Estadística. $1^{\circ}$ ed. Granada: Universidade de Granada.

Brasil- MEC (1997) Secretaria de Educação Fundamental. Parâmetros Curriculares Nacionais - Matemática (Ensino Fundamental e Ensino Médio). Brasília. MEC/SEF.

Brasil- MEC (2002) Secretaria de Educação Média e Tecnológica. PCN+ Ensino Médio: Orientações educacionais complementares aos Parâmetros Curriculares Nacionais. Brasília MEC.

Camargo, A. R (2016) A Estatística na Escola Básica Uma prática de Inferência Informal. Dissertação de Mestrado. Instituto de Matemática e Estatística. São Paulo. USP.

Cazorla, I. M; Kataoka, V. Y. e Silva, C.B. (2010) Trajetória e Perspectivas da Educação Estatística no Brasil: um olhar a partir do GT 12. In: Lopes, C. E; Coutinho, C. Q. S. e Almauloud, S. AG. Estudos e Reflexões em Educação Estatística. (2010) $1^{\text {a }}$ ed. Campinas, SP: Mercado de Letras, p. 19-44.

Christiansen, B. e Walther, G. (1986). Perspectives on mathematics education. Dordrecht: D. Reidel. p. 243-307.

Cordani, L. K. (2005). Estatística para todos. $40^{\circ}$ Reunião Regional da ABE-2005. Universidade Estadual de Maringá.

delMas, R; Garfield, J e Chance, B. (2004) Using assessment to study the development of students reasoning about sampling distributions. Trabalho apresentado na American Educational Research Association. Annual Meeting. California.

Fini, M. I et al. (2008) Proposta curricular do Estado de São Paulo. São Paulo: SEE.

Freire, P. (2011) Pedagogia da autonomia: saberes necessários à prática educativa. $43^{\text {a }}$ ed. São Paulo: Paz e Terra.

Garfield, J. B; Ben-Zvi, D. (2008) Developing students statistical reasoning: Connecting research and teaching practice. New York: Springer.

Hancock, C; Kaput, J. J. e Goldsmith, L. T. (1992) Authentic inquiry into data: Critical barriers to classroom implementation. Educational Psychologist, 27(3), p. 337-364.

Kahneman, D. e Tversky, A. (1973) Availabity: A heuristic for judging frequency and probability. Cognitive psychology, v. 5, n. 2, p. 207-232. 
Lopes, C. E; Coutinho, C. Q. S. e Almauloud, S. AG. (2010) Estudos e Reflexões em Educação Estatística. $1^{\text {a }}$ ed. Campinas, SP: Mercado de Letras, p. 19-44.

Lopes, C. E. (2008) $\mathbf{O}$ ensino da estatística e da probabilidade na educação básica e a formação dos professores. Cad. Cedes, Campinas 28. 74: 57-73.

Machado, N. J. (2005) Epistemologia e didática: as concepções de conhecimento e inteligência múltipla e a prática docente. Cortez.

Machado, N. J. (2015) As ideias fundamentais são poderosas... Disponível em: <www.nilsonjosemachado.net/mil-e-uma-364-as-ideias-fundamentais-sao-poderosas/> . Acessado em 9 de Junho de 2015.

Magalhães, M. N. e Lima, A. C. P. (2010) Noções de Probabilidade e Estatística. $7^{\text {a }}$ ed. São Paulo: Edusp.

Magalhães, M. N. (2014) Desenvolvendo ideias de inferência na educação básica. Oficina $2^{\circ} \mathrm{Sem}$. CAEM - Instituto de Matemática e Estatística.USP.

Makar, K. e Rubin, A. (2009) A framework for thinking about informal statistical inference. Statistics Education Research Journal, v.8, n.1, p.82-105

Makar, K. Bakker, A. e Ben-Zvi, D. (2011). The reasoning behind informal statistical inference. Mathematical Thinking and Learning, 13(1-2), 152-173.

Moore, D. (2007) The basic practice of statistics. $4^{\circ}$ edição. New York: W. H. Freeman and Company.

Pratt, D. e Ainley, J. (2008) Introducing the special issue on informal inference. Statistics Education Research Journal, 7(2), p. 3-4.

Ponte, J. P. (2007) Investigations and explorations in the mathematics classroom. ZDM, 39(5-6), 419-430.

SATS - 36 (2005). Vanhoof, S et al. Measuring statistics atitudes: Structure of the Survey of Attitudes towar Statistics (SATS-36). Statistics Education Research Journal, v. 10, n. 1 , p. $35-51$.

Sônego, D. (2014) A aleatoriedade nos olhos de quem vê. São Paulo: Revista Cálculo, a.4, n.46, p.26-33, nov.

Pirie, S. (1987). Mathematical investigations in your classrooms: A pack for teachers. Macmillan, p. 2. 
Watson, J, M. e Moritz, J, B. (2000) Developing concepts of sampling. Journal for Reserach in Mathematics Education. p. 44-70.

Wild, C. J. e Pfannkuch, M. (1999) Statistical thinking in empirical enquiry. International Statistical Review, 67(3), p. 223-265.

Zeiffler, A; Garfield, J; delMas, R. e Ben-Zvi. (2008) A framework to support research on informal inferencial reasoning. Statistics Education Research Journal, 7(2), 40-58.

\section{Apêndice 1}

\section{NOME:}

\section{FOLHA DE ATIVIDADE 1}

\section{$\mathbf{N}^{\circ} \quad$ ANO:}

Questão 1) Dos fenômenos descritos abaixo, diga qual é aleatório e qual não é, incluindo sua justificativa em cada caso:
a) O tempo de exibição de um certo filme
c) $\mathrm{O}$ resultado da loteria
b) Os dias das estações do ano
d) Duração da bateria do celular

Resolução:

Questão 2) Dê um novo exemplo de fenômeno aleatório e um de determinístico. Qual foi mais fácil para pensar? Porque acha que isso ocorreu?

Resolução:

Questão 3) Para cada uma das situações a seguir diga qual é a população e qual é a amostra.

a) Uma dona de casa deseja testar se sua feijoada está no ponto, ou se falta alguma coisa. Para isso, ela experimenta uma colher de sopa.

b) Para descobrir o índice de rejeição do atual governo o IBOPE fez uma pesquisa nos estados brasileiros levando em conta a escolarização e as classes sociais.

c) Em um experimento de laboratório, um novo remédio contra a degeneração neuronal é testada em ratos, que foram especialmente selecionados de um viveiro e infectados com a doença.

d) Para descobrir se o tempo de duração de uma nova bateria de celular é realmente melhor que a antiga, um grupo de pessoas fez uma discussão na internet. Nesta ocasião, um internauta curioso, reuniu todas as informações que foram postadas em relação ao tempo de duração da bateria.

Resolução: 


\section{Apêndice 2}

\section{NOME: \\ FOLHA DE ATIVIDADE 2 \\ $N^{\circ} \quad$ ANO:}

Questão 1) Faça o sorteio e preencha a tabela abaixo, uma para a variável quantitativa e a outra para a variável qualitativa.

\begin{tabular}{|c|c|c|c|c|c|c|c|c|c|c|}
\hline Amostras & Obs1 & Obs2 & Obs3 & Obs4 & Obs5 & Obs6 & Obs7 & Obs8 & Obs9 & Obs10 \\
\hline Quantitativa & & & & & & & & & & \\
\hline Qualitativa & & & & & & & & & & \\
\hline
\end{tabular}

Questão 2) Represente os dados das tabelas acima, utilizando alguma forma que considere conveniente.

Resolução: 


\section{FOLHA DE ATIVIDADE 2}

\section{NOME: $\mathbf{N}^{\circ}$ ANO:}

Questão 3) Sobre os resultados obtidos:

a) Você percebe alguma tendência?

b) Compare sua amostra com as amostras do seu grupo. Você percebe alguma diferença ou semelhança?

c) Junte todas as amostras do grupo e represente os dados de uma forma conveniente, em seguida, diga se notou alguma diferença em relação aos itens a) e b).

Resolução:

proporção, etc. Baseados nos dados obtidos, para cada variável acima, formule uma afirmação numérica sobre o comportamento dessas variáveis na população.

Resolução: 


\section{Apêndice 3}

NOME:

\section{FOLHA DE ATIVIDADE 3}

\section{$\mathrm{N}^{\circ} \quad$ ANO:}

Questão 1) Utilizando os dados obtidos no quadro da Folha 2, responda as perguntas abaixo:

a) Complete o quadro abaixo, para a variável quantitativa:

\begin{tabular}{|c|c|c|c|}
\hline Medidas & Mínimo & Máximo & Média \\
\hline Valores & & & \\
\hline
\end{tabular}

b) Você conseguiria efetuar estes cálculos para a variável qualitativa?

c) Justifique a "diferença" com a variável qualitativa.

Resolução:

Questão 2) (apenas para a variável quantitativa). De posse da sua afirmação numérica:

a) Coloque seu valor no centro da figura abaixo e crie um critério para dar uma "folga" ou "erro" para sua afirmação e anote no intervalo.

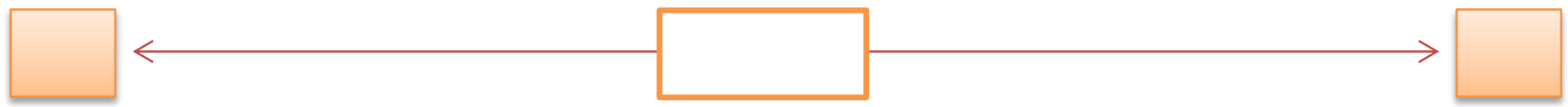

b) Explique o critério utilizado.

Resolução:

Questão 3) Analise seu resultado comparando com o valor verdadeiro, para isso utilize todos os dados do quadro de pesquisa. Comente. 
FOLHA DE ATIVIDADE 3

NOME: $\quad \mathbf{N}^{\circ}$ ANO:

Resolução:

Resolução: 


\section{Apêndice 4}

\section{Teste Inicial de Atitudes}

PSEUDÔNIMO:

DATA:

Preencha a tabela abaixo, atribuindo uma nota de 0 a 5 , em que 0 significa "totalmente errado" e 5 "plenamente certo".

\begin{tabular}{|l|l|}
\hline Perguntas: & Nota \\
\hline Eu irei gostar de Estatística. & \\
\hline As Estatísticas são raramente presentes na vida real. & \\
\hline Eu uso Estatística no meu cotidiano. & \\
\hline Eu planejo estudar muito nas atividades de Estatística. & \\
\hline As pessoas usam um novo jeito de pensar para estudar Estatística. & \\
\hline Estatística é uma matéria difícil. & \\
\hline Eu me sentirei inseguro quando estiver estudando problemas de Estatística. & \\
\hline Eu posso aprender Estatística. & \\
\hline Estatística é irrelevante para minha vida. & \\
\hline Eu vou achar muito difícil compreender os conceitos de Estatística. & \\
\hline Eu estou interessado em entender as informações Estatísticas. & \\
\hline Eu fico assustado com Estatística. & \\
\hline Eu estou interessado em usar Estatística. & \\
\hline
\end{tabular}




\section{Apêndice 5}

\section{Teste Final de Atitudes}

PSEUDÔNIMO:

DATA:

Preencha a tabela abaixo, atribuindo uma nota de 0 a 5 , em que 0 significa "totalmente errado" e 5 "plenamente certo".

\begin{tabular}{|l|l|}
\hline Perguntas: & Nota \\
\hline Eu gostei de estudar Estatística. & \\
\hline As Estatísticas são raramente presentes na vida real. & \\
\hline Eu uso Estatística no meu cotidiano. & \\
\hline Eu vou estudar muito nas atividades de Estatística. & \\
\hline As pessoas usam um novo jeito de pensar para estudar Estatística. & \\
\hline Estatística foi uma matéria difícil. & \\
\hline Eu vou me sentir inseguro quando estiver estudando problemas de Estatística. & \\
\hline Eu posso aprender Estatística. & \\
\hline Estatística é irrelevante para minha vida. & \\
\hline Eu achei muito difícil compreender os conceitos de Estatística. & \\
\hline Eu estou interessado em entender as informações Estatísticas. & \\
\hline Eu fiquei assustado com Estatística. & \\
\hline Eu estou interessado em usar Estatística. & \\
\hline
\end{tabular}




\section{Apêndice 6}

\section{Teste Inicial de Conteúdo}

1) Uma maquete foi construída na razão 1:40. Se a altura de uma casa na maquete for de $90 \mathrm{~cm}$, qual é a altura real dessa casa?

Resolução

2) Um carro foi vendido por $R \$ 10.000,00$, com prejuízo de $20 \%$ sobre o preço da compra. O carro havia sido comprado, em reais, por:

Resolução

3) A lista do número de irmãos dos alunos de uma turma do $3^{\circ}$ ano é a seguinte:

\begin{tabular}{|l|l|l|l|l|l|l|l|l|l|l|l|l|}
\hline $\mathbf{1}$ & $\mathbf{0}$ & $\mathbf{1}$ & $\mathbf{2}$ & $\mathbf{1}$ & $\mathbf{1}$ & $\mathbf{1}$ & $\mathbf{3}$ & $\mathbf{0}$ & $\mathbf{4}$ & $\mathbf{0}$ & $\mathbf{1}$ & $\mathbf{1}$ \\
\hline $\mathbf{4}$ & $\mathbf{2}$ & $\mathbf{3}$ & $\mathbf{2}$ & $\mathbf{1}$ & $\mathbf{3}$ & $\mathbf{1}$ & $\mathbf{2}$ & $\mathbf{1}$ & $\mathbf{2}$ & $\mathbf{1}$ & $\mathbf{2}$ & $\mathbf{3}$ \\
\hline
\end{tabular}

a) Faça uma tabela de frequência com os dados.

b) Complete a tabela com a frequência relativa e as devidas porcentagens.

c) Calcule a média, moda, mediana e amplitude dos dados.

Resolução 


\section{Teste Inicial de Conteúdo}

4. A partir do desempenho em química demonstrado pelos alunos de uma turma, um professor elaborou a seguinte tabela. Faça o gráfico de barras para ilustrar os resultados.

\begin{tabular}{l|c|c}
\hline Desempenho & $f$ & $\mathrm{fr}$ \\
\hline Insuficiente & 6 & $15 \%$ \\
Regular & 10 & $25 \%$ \\
Bom & 14 & $35 \%$ \\
Ótimo & 10 & $25 \%$ \\
\hline Total & 40 & $100 \%$ \\
\hline
\end{tabular}

5. Relacione corretamente as colunas abaixo, de acordo com a semelhança dos conceitos.
i. AMOSTRA
ii. ESTATÍSTICA
iii. POPULAÇÃO

iv. VARIÁVEL

v. DADOS
( Estudo de números associados à fenômenos

( ) Parte da população observada

( ) Denominação dada à atributos ou quantidades, que variam quanto à grandeza.

( ) Grupo de indivíduos ou coisas cujas características são estudadas.

( ) Cada valor observado de uma variável. 


\section{Apêndice 7}

\section{Teste Final de Conteúdo}

1) Alguns vendedores de carros foram selecionados, no último mês, e anotou-se o número de vendas de um determinado carro da marca $X$, que em ordem crescente foram: $2,4,7,10,10,10,12,12,14,15$. Determine: (a) população em estudo, (b) amostra, (c) média, (d) mediana, (e) moda, (f) De um palpite sobre as vendas dos carros da marca X no próximo mês? Justifique.

\section{RESOLUÇÃO}

2) (Adaptado ENEM) Uma empresa em ascendência no ramo dos negócios alimentícios deseja contratar novos gerentes. Para tanto, o diretor executivo da empresa, entrevistou quatro candidatos aprovados por uma seletiva de mais de mil concorrentes para a vaga, dos quais passaram por uma prova de conhecimentos e uma dinâmica de grupo. Os resultados dos candidatos selecionados, descritos abaixo com notas de 0 até 100, foram:

\begin{tabular}{|c|c|c|c|c|c|c|c|c|c|c|}
\hline Candidatos & Específicos & Atualidades & Português & Matemática & Dinâmica & Entrevista & Média & Moda & Mediana & $\begin{array}{c}\text { D. } \\
\text { Padrão }\end{array}$ \\
\hline Marco & 100 & 80 & 80 & 70 & 85 & 65 & 80 & 80 & 80 & 12,24745 \\
\hline Paulo & 70 & 80 & 90 & 80 & 80 & 80 & 80 & 80 & 80 & 6,324555 \\
\hline Letícia & 60 & 90 & 80 & 80 & 70 & 100 & 80 & 80 & 80 & 14,14214 \\
\hline Amanda & 80 & 100 & 70 & 80 & 60 & 90 & 80 & 80 & 80 & 14,14214 \\
\hline
\end{tabular}

Sabendo que o diretor precisa de uma presença feminina na empresa e que ele precisa selecionar dois novos gerentes, de acordo com a tabela acima, quais seriam os candidatos contratados? Justifique.

RESOLUÇÃO: 


\section{Teste Final de Conteúdo}

3) (OBMEP 2013) O gráfico mostra o número de casos notificados de dengue, a precipitação de chuva e a temperatura média, por semestre, dos anos de 2007 a 2010 em uma cidade brasileira.

Podemos afirmar que:

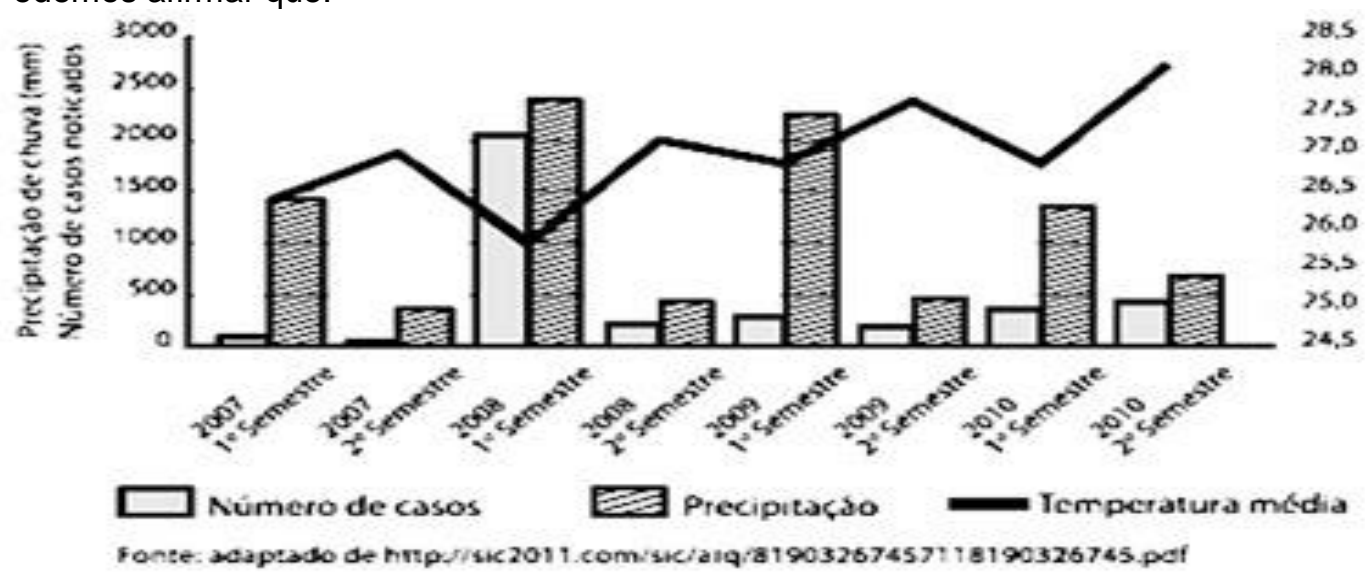

A) O período de maior precipitação foi o de maior temperatura média e com o maior número de casos de dengue notificados.

B) O período com menor número de casos de dengue notificados também foi o de maior temperatura média.

C) O período de maior temperatura média foi também o de maior precipitação.

D) O período de maior precipitação não foi o de maior temperatura média e teve o maior número de casos de dengue notificados.

E) Quanto maior a precipitação em um período, maior o número de casos de dengue notificados.

4) Um fabricante afirma que a média de vida útil das lâmpadas por ele fabricadas é de 4.200 horas. A média da vida útil para uma amostra com dez lâmpadas é de 4.000 horas. $O$ que você acha da afirmação do fabricante? Justifique.

RESOLUÇÃO: 
1.1 - Termo de Consentimento Escola.

\section{Apêndice 8}

\section{TERMO DE CONSENTIMENTO LIVRE E ESCLARECIDO}

Eu compreendo os direitos dos participantes da pesquisa intitulada "Ensino de Estatística na Escola Básica por meio da Inferência Informal", orientada por Marcos Nascimento Magalhães, e que tem como pesquisador responsável Vinicius Alves Rodrigues, estudante do Instituto de Matemática e Estatística da Universidade de São Paulo, os quais podem ser contatados pelos e-mails valves@ime.usp.br e marcos@ime.usp.br ou telefones (11)97046-4431 e (11)3091-6123. Na qualidade de responsável pela Escola Liceu Carvalho Pinto, autorizo a participação de estudantes na mencionada pesquisa e compreendo como e porque esse estudo está sendo realizado. Os responsáveis pela pesquisa garantem o sigilo, assegurando a privacidade dos sujeitos quanto aos dados envolvidos na pesquisa. Receberei uma cópia assinada deste formulário de consentimento.

São Paulo, de de 2016.

Nome:

Cargo:

Assinatura: 


\section{Apêndice 9}

\section{TERMO DE CONSENTIMENTO LIVRE E ESCLARECIDO}

Concordo em participar, como voluntário/a, da pesquisa intitulada "Ensino de Estatística na Educação Básica por meio da Inferência Informal", que tem como pesquisador responsável Vinicius Alves Rodrigues, estudante do Instituto de Matemática e Estatística da Universidade de São Paulo, orientado por Marcos Nascimento Magalhães, os quais podem ser contatados pelos e-mails valves@ime.usp.br e marcos@ime.usp.br ou telefone (11)97046-4431 e (11)3091-6123. O presente trabalho tem por objetivo criar um material didático e significativo para o ensino de Estatística na Educação Básica por meio de atividades investigativas. Minha participação consistirá em realizar os testes e da dinâmica em sala de aula. Compreendo que esse estudo possui finalidade de pesquisa, e que os dados obtidos serão divulgados seguindo as diretrizes éticas da pesquisa, assegurando, assim, minha privacidade. Sei que posso retirar meu consentimento quando eu quiser, e que não receberei nenhum pagamento por essa participação.

São Paulo,

de

de 2016 .

Nome:

Assinatura: 


\section{Apêndice 10}

\section{TERMO DE CONSENTIMENTO LIVRE E ESCLARECIDO}

$\mathrm{Eu}$, RG

declaro saber da participação de meu/minha filho/a na pesquisa "Ensino de Estatística na Educação Básica por meio da Inferência Informal", desenvolvida junto ao Instituto de Matemática e Estatística da Universidade de São Paulo pelo pesquisador Vinicius Alves Rodrigues, orientado por Marcos Nascimento Magalhães, os quais podem ser contatados pelos e-mails valves@ime.usp.br e marcos@ime.usp.br ou telefones (11)97046-4431 e (11)3091-6123. O presente trabalho tem por objetivo criar um material didático e significativo para o ensino de Estatística na Educação Básica por meio de atividades investigativas, e os instrumentos utilizados são: Pesquisa de Atitudes, Teste Diagnóstico e de Conteúdo, Dinâmica em sala de aula com gravação de áudio. Compreendo que tenho liberdade de retirar o meu consentimento em qualquer fase da pesquisa, sem penalização alguma. A qualquer momento, posso buscar maiores esclarecimentos, inclusive relativos à metodologia do trabalho. Os responsáveis pela pesquisa garantem o sigilo, assegurando a privacidade dos sujeitos quanto aos dados envolvidos na pesquisa. Declaro compreender que as informações obtidas só podem ser usadas para fins científicos, de acordo com a ética na pesquisa, e que essa participação não inclui nenhum tipo de pagamento.

$$
\text { São Paulo, de de } 2016 .
$$

Nome: 


\section{Apêndice 11}

\begin{tabular}{|c|c|c|c|c|c|c|c|c|c|}
\hline \multirow[b]{2}{*}{ Sentido } & \multirow[t]{2}{*}{ Pesquisa de Atitude } & \multicolumn{2}{|c|}{ Kian L } & \multicolumn{2}{|c|}{ Coração } & \multicolumn{2}{|c|}{ Preguiça } & \multicolumn{2}{|c|}{ Matheus } \\
\hline & & Antes & Depois & Antes & Depois & Antes & Depois & Antes & Depois \\
\hline+ & Eu irei gostar de Estatística & 3 & 1 & 4 & 4 & 4 & 3,5 & 5 & 5 \\
\hline+ & $\begin{array}{l}\text { Eu uso Estatística no meu } \\
\text { cotidiano }\end{array}$ & 5 & 0 & 3 & 3 & 5 & 4 & 3 & 3 \\
\hline+ & Eu posso aprender Estatística & 5 & 5 & 4 & 5 & 5 & 5 & 5 & 5 \\
\hline+ & $\begin{array}{l}\text { Eu estou interessado em } \\
\text { entender as informações } \\
\text { Estatísticas }\end{array}$ & 4 & 5 & 2 & 3 & 3 & 3 & 5 & 4 \\
\hline+ & $\begin{array}{l}\text { Eu estou interessado em usar } \\
\text { Estatística }\end{array}$ & 3 & 2 & 3 & 3 & 3 & 4 & 3 & 3 \\
\hline+ & $\begin{array}{l}\text { As pessoas usam um novo jeito } \\
\text { de pensar para estudar } \\
\text { Estatística }\end{array}$ & 5 & 2 & 3 & 4 & 4 & 4 & 5 & 5 \\
\hline- & $\begin{array}{l}\text { As Estatísticas são raramente } \\
\text { presentes na vida real }\end{array}$ & 0 & 0 & 5 & 3 & 5 & 4 & 3 & 3 \\
\hline- & Estatística é uma matéria difícil & 2 & 5 & 0 & 2 & 2 & 4 & 2 & 4 \\
\hline- & $\begin{array}{l}\text { Eu me sentirei inseguro quando } \\
\text { estiver estudando problemas de } \\
\text { Estatística }\end{array}$ & 3 & 3 & 3 & 2 & 2 & 3 & 1 & 2 \\
\hline- & $\begin{array}{l}\text { Estatística é irrelevante para } \\
\text { minha vida }\end{array}$ & 0 & 0 & 0 & 0 & 0 & 0 & 0 & 1 \\
\hline- & $\begin{array}{l}\text { Eu vou achar muito difícil } \\
\text { compreender os conceitos de } \\
\text { Estatística }\end{array}$ & 2 & 4 & 0 & 0 & 1 & 3 & 1 & 3 \\
\hline - & Eu fico assustado com Estatística & 2 & 3 & 0 & 0 & 0 & 2 & 0 & 2 \\
\hline
\end{tabular}




\begin{tabular}{|c|l|c|c|c|c|c|c|c|c|}
\hline \multirow{2}{*}{} & Pesquisa de Atitude & \multicolumn{2}{|c|}{00.7} & \multicolumn{2}{c|}{ Paulo R. } & \multicolumn{2}{c|}{ Lauren } & \multicolumn{2}{|c|}{ Jucrécio } \\
\hline Sentido & Antes & Depois & Antes & Depois & Antes & Depois & Antes & Depois \\
\hline+ & Eu irei gostar de Estatística & 4 & 4 & 4 & 5 & 3 & 3,5 & 3 & 3 \\
\hline+ & $\begin{array}{l}\text { Eu uso Estatística no meu } \\
\text { cotidiano }\end{array}$ & 4 & 4 & 5 & 4 & 3 & 3,5 & 3 & 4 \\
\hline+ & $\begin{array}{l}\text { Eu posso aprender Estatística } \\
\text { Eu estou interessado em } \\
\text { entender as informações }\end{array}$ & 5 & 5 & 5 & 5 & 5 & 4 & 5 & 5 \\
\hline+ & $\begin{array}{l}\text { Estatísticas } \\
\text { Eu estou interessado em usar } \\
\text { Estatística }\end{array}$ & 4 & 3 & 5 & 4 & 3 & 3,25 & 0 & 2 \\
\hline+ & $\begin{array}{l}\text { As pessoas usam um novo } \\
\text { jeito de pensar para estudar } \\
\text { Estatística }\end{array}$ & 5 & 3 & 2 & 5 & 4 & 2,5 & 2 & 5 \\
\hline- & $\begin{array}{l}\text { As Estatísticas são raramente } \\
\text { presentes na vida real }\end{array}$ & 5 & 0 & 0 & 0 & 1 & 4,25 & 5 & 5 \\
\hline- & $\begin{array}{l}\text { Estatística é uma matéria } \\
\text { difícil }\end{array}$ & 3 & 2 & 2 & 2 & 2 & 3 & 2 & 4 \\
\hline- & $\begin{array}{l}\text { Eu me sentirei inseguro } \\
\text { quando estiver estudando } \\
\text { problemas de Estatística }\end{array}$ & 2 & 1 & 1 & 0 & 3 & 3,5 & 3 & 0 \\
\hline- & $\begin{array}{l}\text { Estatística é irrelevante para } \\
\text { minha vida }\end{array}$ & 2 & 1 & 0 & 0 & 0 & 2 & 5 & 0 \\
\hline- & $\begin{array}{l}\text { Eu vou achar muito difícil } \\
\text { compreender os conceitos de } \\
\text { Estatística }\end{array}$ & 2 & 1 & 0 & 0 & 3 & 3,5 & 3 & 2 \\
\hline & $\begin{array}{l}\text { Eu fico assustado com } \\
\text { Estatística }\end{array}$ & 3 & 0 & 1 & 0 & 1 & 2,5 & 1 & 0 \\
\hline
\end{tabular}




\begin{tabular}{|c|c|c|c|c|c|c|c|}
\hline \multirow[b]{2}{*}{ Sentido } & \multirow[t]{2}{*}{ Pesquisa de Atitude } & \multicolumn{2}{|c|}{ Miley } & \multicolumn{2}{|c|}{ Manuela } & \multicolumn{2}{|c|}{ Goku } \\
\hline & & Antes & Depois & Antes & Depois & Antes & Depois \\
\hline+ & Eu irei gostar de Estatística & 3 & 2 & 4 & 3 & 2 & 4 \\
\hline+ & $\begin{array}{l}\text { Eu uso Estatística no meu } \\
\text { cotidiano }\end{array}$ & 3 & 5 & 2 & 2 & 3 & 3 \\
\hline+ & Eu posso aprender Estatística & 5 & 4 & 5 & 4 & 5 & 5 \\
\hline+ & $\begin{array}{l}\text { Eu estou interessado em } \\
\text { entender as informações } \\
\text { Estatísticas }\end{array}$ & 5 & 2 & 3 & 3 & 4 & 3 \\
\hline+ & $\begin{array}{l}\text { Eu estou interessado em usar } \\
\text { Estatística }\end{array}$ & 4 & 2 & 3 & 3 & 2 & 3 \\
\hline+ & $\begin{array}{l}\text { As pessoas usam um novo jeito } \\
\text { de pensar para estudar } \\
\text { Estatística }\end{array}$ & 4 & 4 & 3 & 3 & 3 & 5 \\
\hline- & $\begin{array}{l}\text { As Estatísticas são raramente } \\
\text { presentes na vida real }\end{array}$ & 0 & 0 & 0 & 4 & 2 & 1 \\
\hline- & Estatística é uma matéria difícil & 2 & 3.5 & 1 & 3 & 4 & 1 \\
\hline- & $\begin{array}{l}\text { Eu me sentirei inseguro quando } \\
\text { estiver estudando problemas de } \\
\text { Estatística }\end{array}$ & 3 & 3.5 & 1 & 4 & 2 & 2 \\
\hline- & $\begin{array}{l}\text { Estatística é irrelevante para } \\
\text { minha vida }\end{array}$ & 1 & 1 & 2 & 2 & 0 & 2 \\
\hline- & $\begin{array}{l}\text { Eu vou achar muito difícil } \\
\text { compreender os conceitos de } \\
\text { Estatística }\end{array}$ & 3 & 3.5 & 1 & 4 & 3 & 1 \\
\hline - & Eu fico assustado com Estatística & 2 & 3.5 & 1 & 4 & 1 & 1 \\
\hline
\end{tabular}




\begin{tabular}{|c|l|c|c|c|c|c|c|}
\hline \multirow{2}{*}{} & Pesquisa de Atitude & \multicolumn{2}{|c|}{ Lind } & \multicolumn{2}{c|}{ Winches } & \multicolumn{2}{c|}{ Sinfo } \\
\hline Sentido & Antes & Depois & Antes & Depois & Antes & Depois \\
\hline+ & Eu irei gostar de Estatística & 4 & 2 & 4 & 3 & 4 & 4 \\
\hline+ & Eu uso Estatística no meu cotidiano & 5 & 5 & 3 & 2 & 4 & 4 \\
\hline+ & Eu posso aprender Estatística & 4 & 5 & 5 & 5 & 5 & 5 \\
\hline+ & $\begin{array}{l}\text { Eu estou interessado em entender } \\
\text { as informações Estatísticas }\end{array}$ & 5 & 3 & 4 & 3 & 5 & 4 \\
\hline+ & $\begin{array}{l}\text { Eu estou interessado em usar } \\
\text { Estatística }\end{array}$ & 4 & 2 & 3 & 3 & 4 & 3 \\
\hline+ & $\begin{array}{l}\text { As pessoas usam um novo jeito de } \\
\text { pensar para estudar Estatística }\end{array}$ & 3 & 4 & 5 & 3 & 5 & 5 \\
\hline- & $\begin{array}{l}\text { As Estatísticas são raramente } \\
\text { presentes na vida real }\end{array}$ & 5 & 0 & 3 & 2 & 5 & 0 \\
\hline- & \begin{tabular}{l} 
Estatística é uma matéria difícil \\
\hline-
\end{tabular} & 2 & 2 & 0 & 1 & 2 & 2 \\
\hline- & $\begin{array}{l}\text { Eu me sentirei inseguro quando } \\
\text { estiver estudando problemas de } \\
\text { Estatística }\end{array}$ & 1 & 1 & 3 & 3 & 4 & 1 \\
\hline- & $\begin{array}{l}\text { Estatística é irrelevante para minha } \\
\text { vida }\end{array}$ & 1 & 0 & 2 & 1 & 0 & 0 \\
\hline & $\begin{array}{l}\text { Eu vou achar muito difícil } \\
\text { compreender os conceitos de } \\
\text { Estatística }\end{array}$ & 1 & 3 & 1 & 2 & 2 & 2 \\
\hline Eu fico assustado com Estatística & 2 & 1 & 1 & 2 & 1 & 2 \\
\hline
\end{tabular}

O leitor também pode verificar a tabela de pontuações dos alunos por meio do seguinte link:

https://drive.google.com/file/d/0B4nYSFW6G5CdNlE3bmJnWWRldFU/view?usp=sharin g. 


\section{Apêndice 12}

\section{1- Gostar de Estatística.}

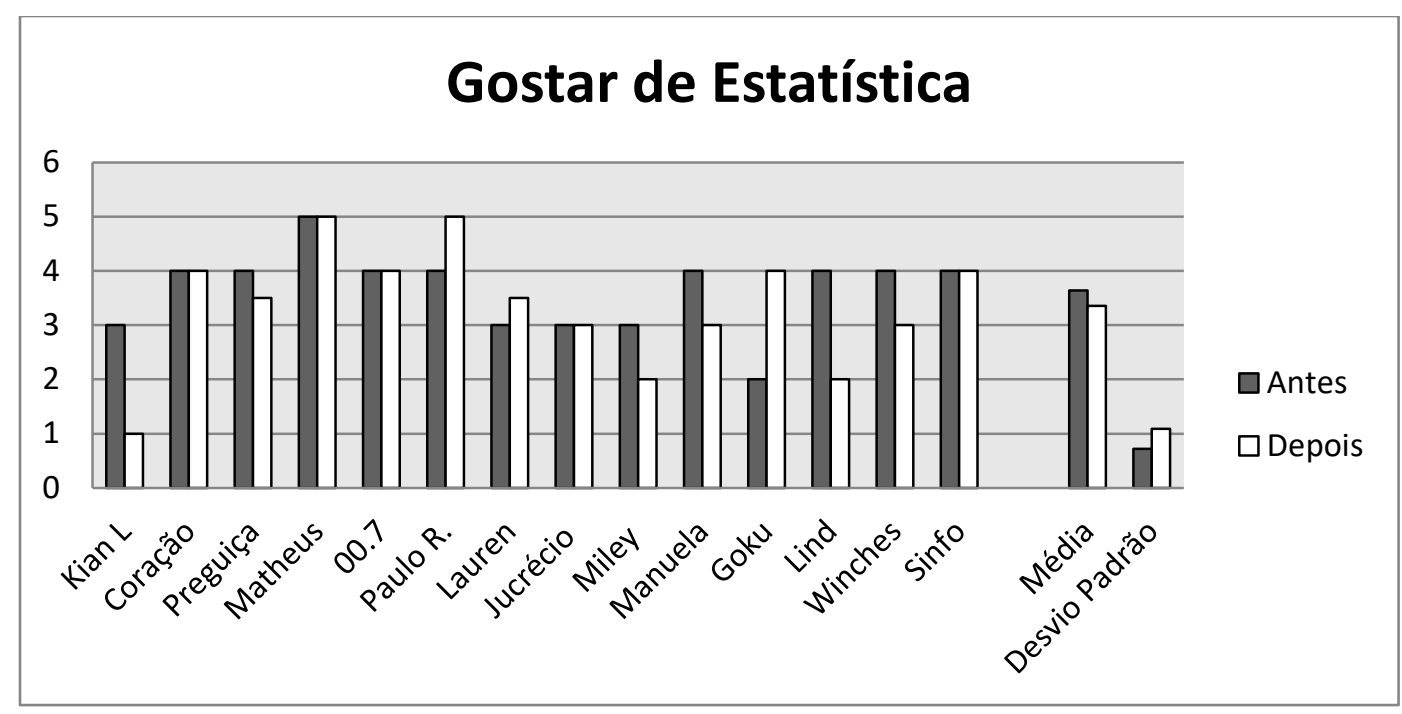

Figura 19: Teste de Atitudes - Gostar de Estatística

Podemos perceber que as duas médias, antes e depois, ficaram próximas. O desvio padrão pequeno nos dois momentos nos mostra que não teve grandes variações nos dados. Apenas destacamos os alunos Kian L e Lind, que diminuiram dois pontos depois da aplicação da atividade, e o aluno Goku, que subiu dois pontos. Para os demais não observamos outras mudanças significativas.

Apesar dos dados praticamente não terem sofrido muitas alterações, uma média de 3,5 pontos mostra que temos uma boa média indicando que os alunos, no geral, gostam de Estatística. 


\section{2- Uso de Estatística no Cotidiano.}

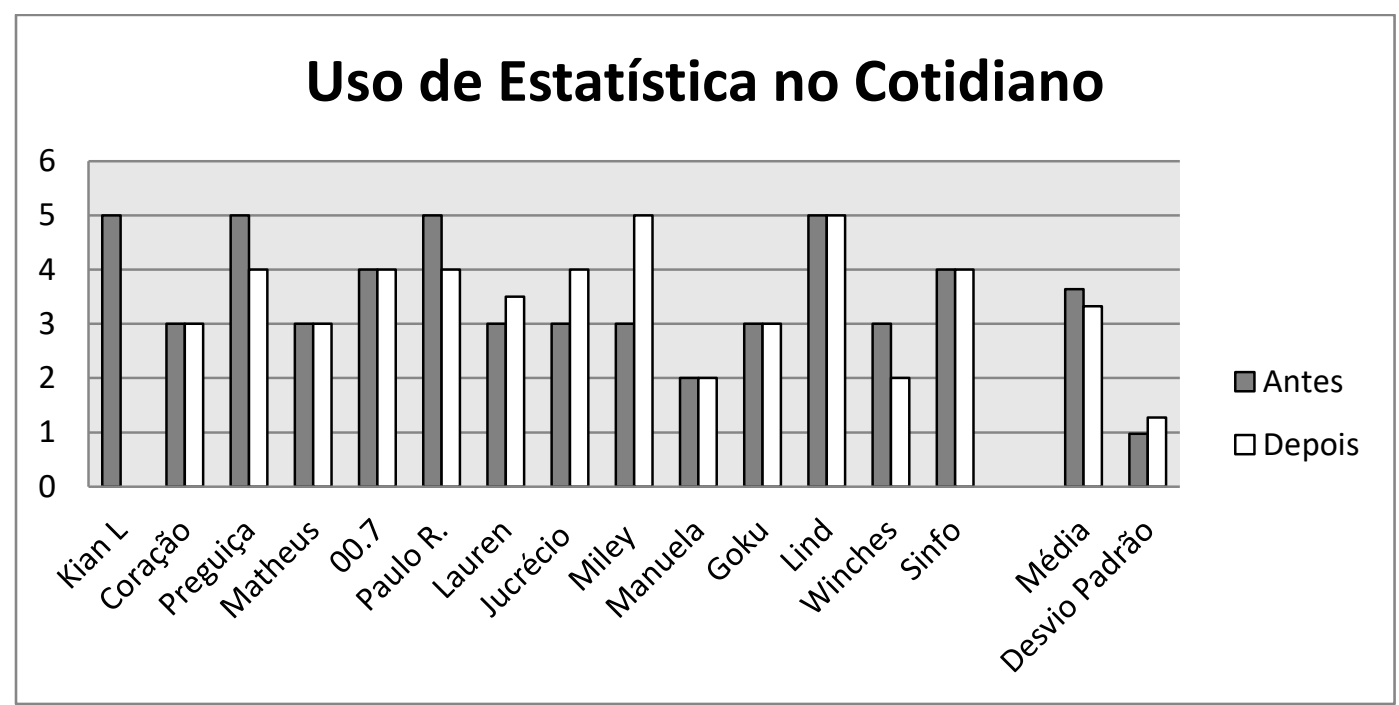

Figura 20: Teste de Atitudes - Uso de Estatística no Cotidiano

Podemos perceber que as duas médias, antes e depois, ficaram próximas. O desvio padrão pequeno nos dois momentos nos mostra que não teve grandes variações nos dados. Destacamos o aluno Kian L, que diminuiu todos os pontos depois da aplicação da atividade, evidenciado a decepção do aluno quanto ao uso da Estatística no cotidiano. Isto pode ser que o estudante tivesse grandes expectativas quanto ao uso da Estatística no seu cotidiano e acabou se decepcionando.

Apesar dos dados praticamente não terem sofrido muitas alterações, uma média de 3,5, mostra que temos uma boa média indicando que os alunos, no geral, conseguiram perceber o uso da Estatística no seu cotidiano. 


\section{3- Aprender Estatística}

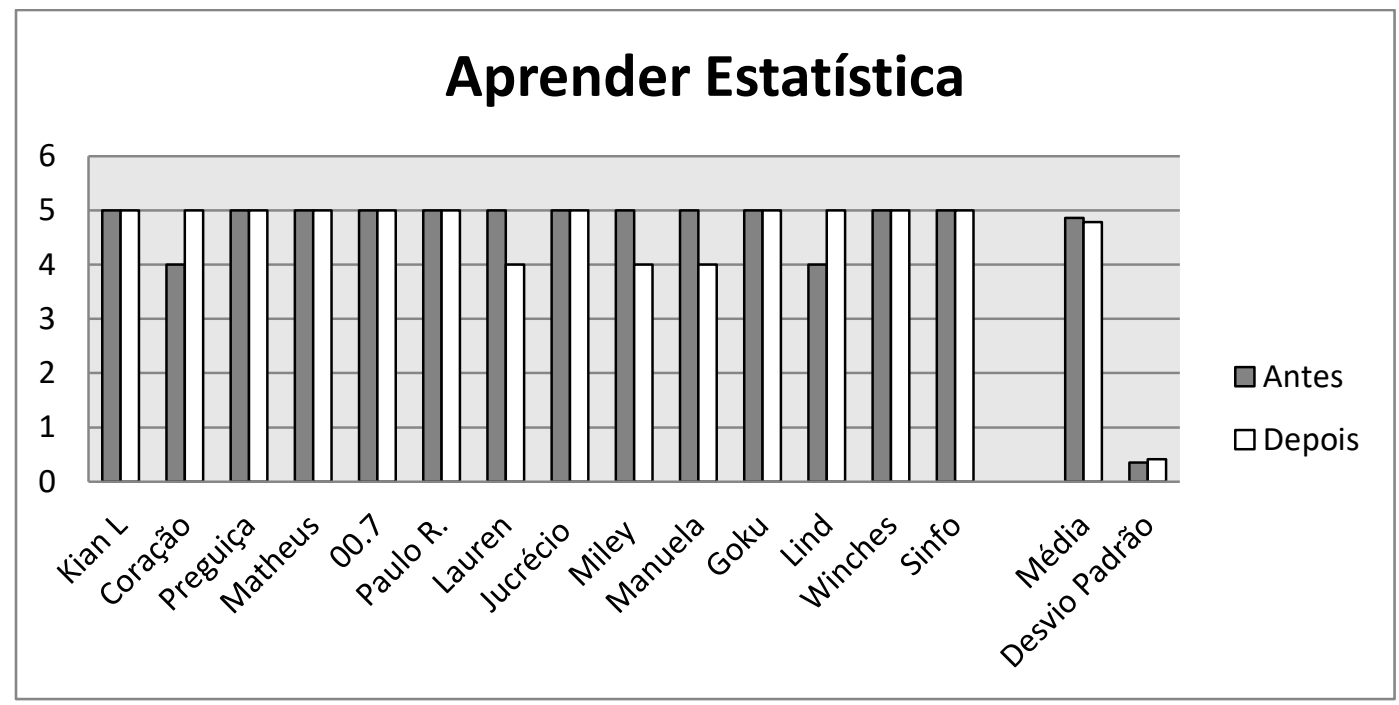

Figura 21: Teste de Atitudes - Aprender Estatística

Podemos perceber que as duas médias, antes e depois, ficaram próximas. O desvio padrão muito pequeno nos dois momentos nos mostra que teve um variação muito pequena nos dados. Apesar dos dados praticamente não terem sofrido muitas alterações, uma média de quase 5, mostra que temos uma ótima média e que os estudantes demonstraram que podem aprender Estatística, dentro da dinâmica que os temas foram trabalhados. 


\section{4- Entender as informações Estatísticas.}

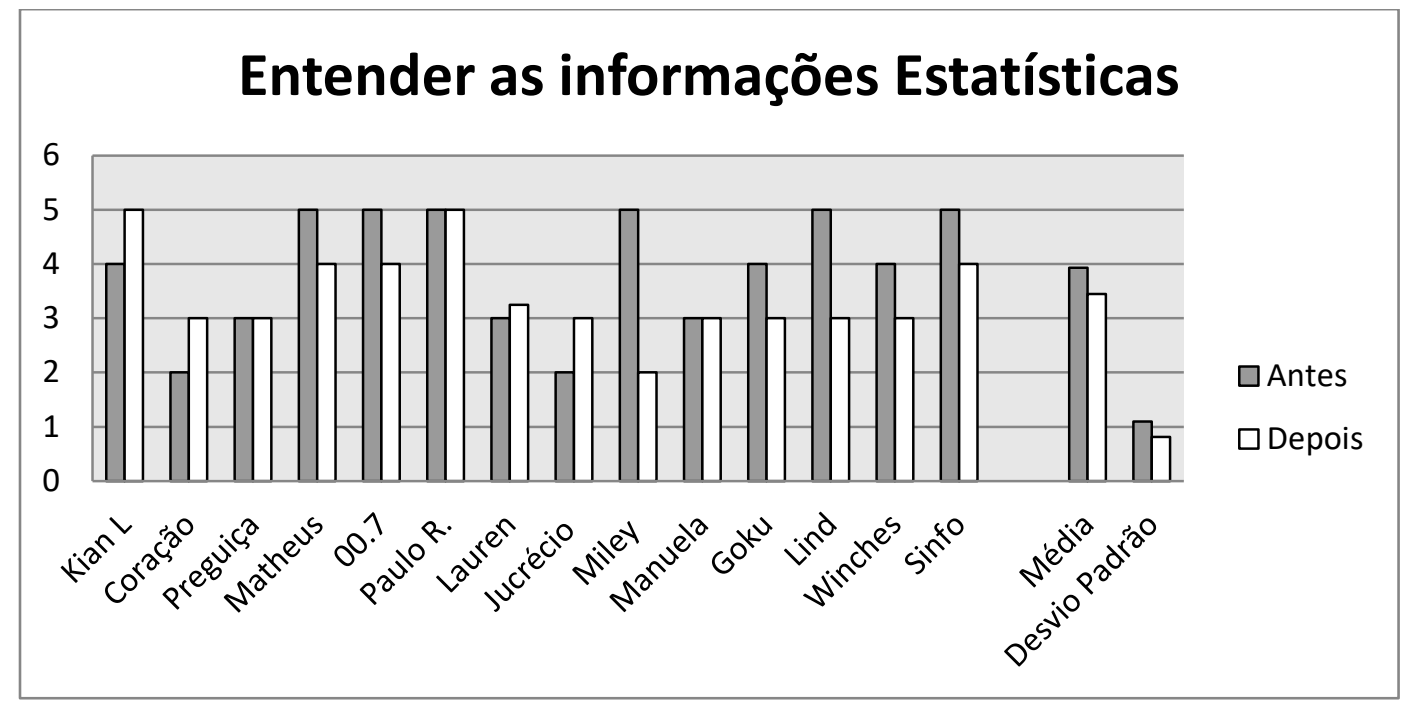

Figura 22: Teste de Atitudes - Entender as informações Estatísticas

Podemos perceber que as duas médias, antes e depois, ficaram próximas apesar de que a média depois acabou tendo um desnível um pouco maior. $\mathrm{O}$ desvio padrão pequeno nos dois momentos nos mostra que não teve grandes variações nos dados. Destacamos a aluna Miley, que diminuiu três pontos depois da atividade, evidenciando que neste caso, para a estudante, ficou um pouco mais difícil de entender as informações Estatísticas depois da atividade.

Contudo, no geral, os alunos ainda mantiveram uma boa média próxima de 3,5 pontos, indicando que mesmo com uma atividade que envolva o trabalho investigativo em que para obter as informações o aluno deve de esforçar mais nesse processo, coletando dados, montando gráficos, fazendo testes, analisando os resultados, eles mostraram que continuam a entender as informações da Estatística. 


\section{5- Interessado em usar Estatística}

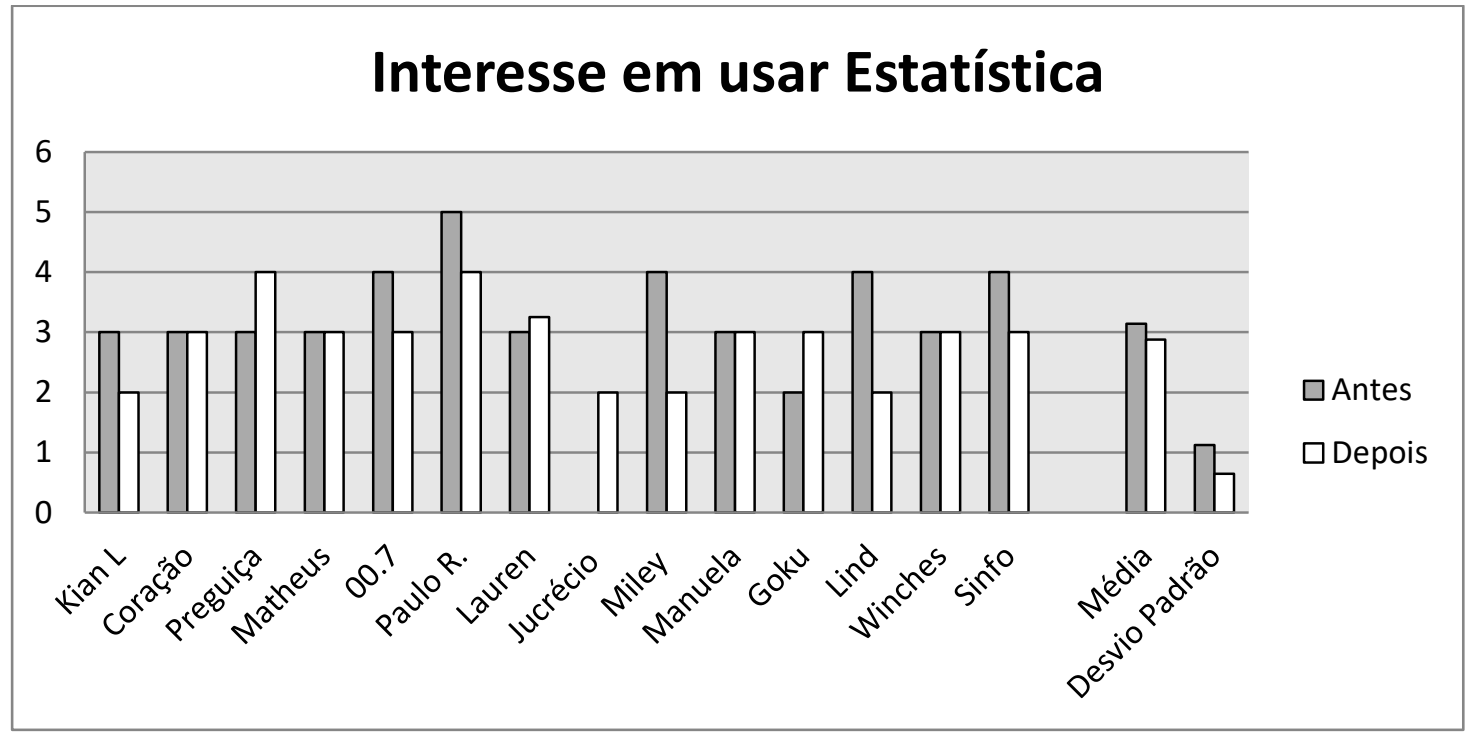

Figura 23: Teste de Atitudes - Interesse em usar Estatística

Podemos perceber que as duas médias, antes e depois, ficaram próximas. O desvio padrão pequeno nos dois momentos nos mostra que não teve grandes variações nos dados. Destacamos os alunos Miley e Lind, que diminuíram dois pontos depois da atividade, indicando que, para as estudantes, o interesse delas em usar Estatística ficou um pouco menor depois da atividade.

As médias desta pergunta ficaram próximas de 3 pontos, indicando uma média razoável, um pouco maior que a metade, evidenciando que os estudantes demonstram um interesse em usar Estatística, apesar de parecer um pouco mais "tímido" depois da aplicação da atividade. 
6- Novo jeito de pensar para estudar Estatística

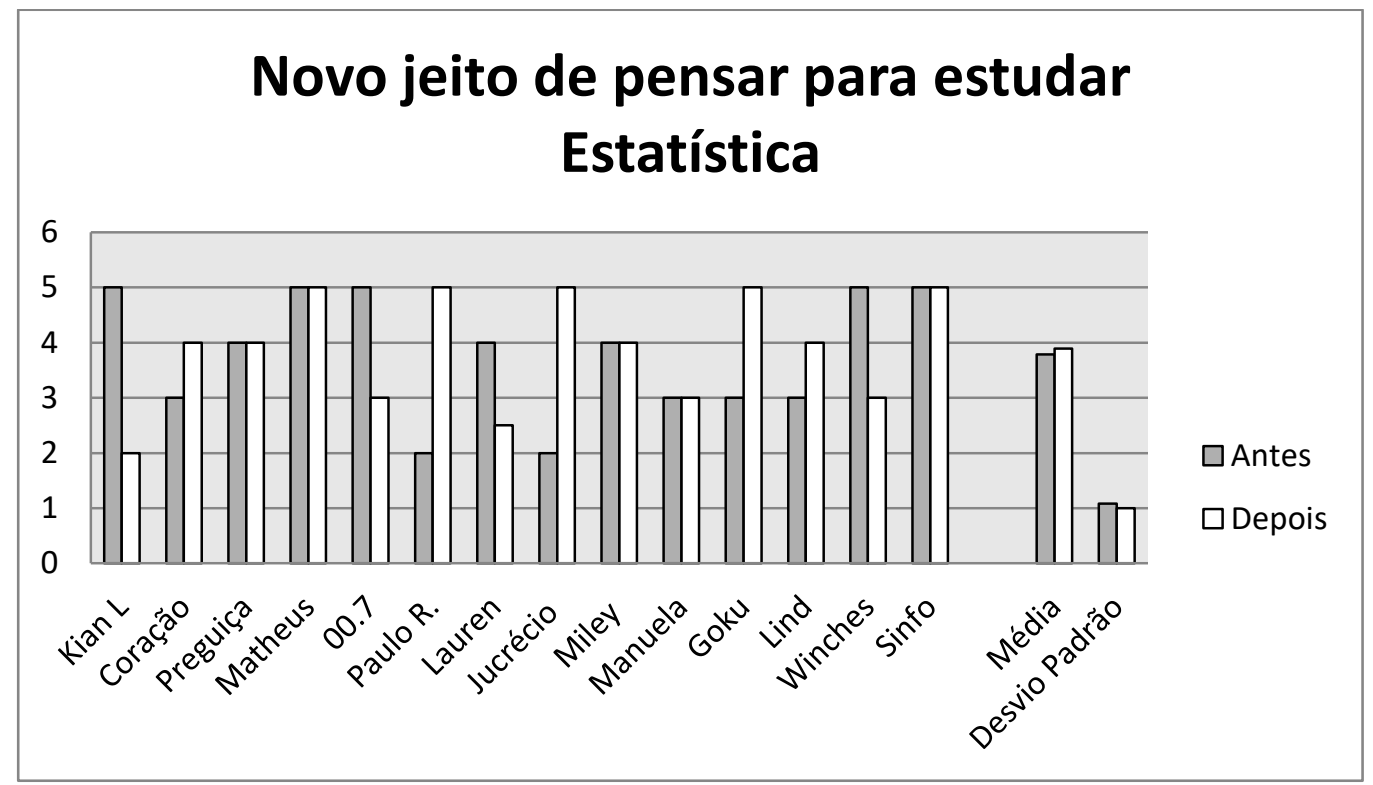

Figura 24: Teste de Atitudes - Novo jeito de pensar para estudar Estatística

Podemos perceber que as duas médias, antes e depois, ficaram próximas apesar de que a média depois acabou sendo um pouco maior. $O$ desvio padrão pequeno nos dois momentos nos mostra que não teve grandes variações nos dados. Destacamos a aluna Kian $\mathrm{L}$, que diminuiu três pontos depois da atividade, evidenciando que neste caso, para a estudante, a Estatística depois da atividade não mostrou que utiliza um novo jeito de pensar.

Contudo, no geral, os alunos ainda mantiveram uma boa média próxima de 3,5, indicando que os estudantes acabaram percebendo que no geral, eles perceberam que a Estatística utiliza um raciocínio diferente para estudar os problemas. 
7- As Estatísticas são raramente presentes na vida real

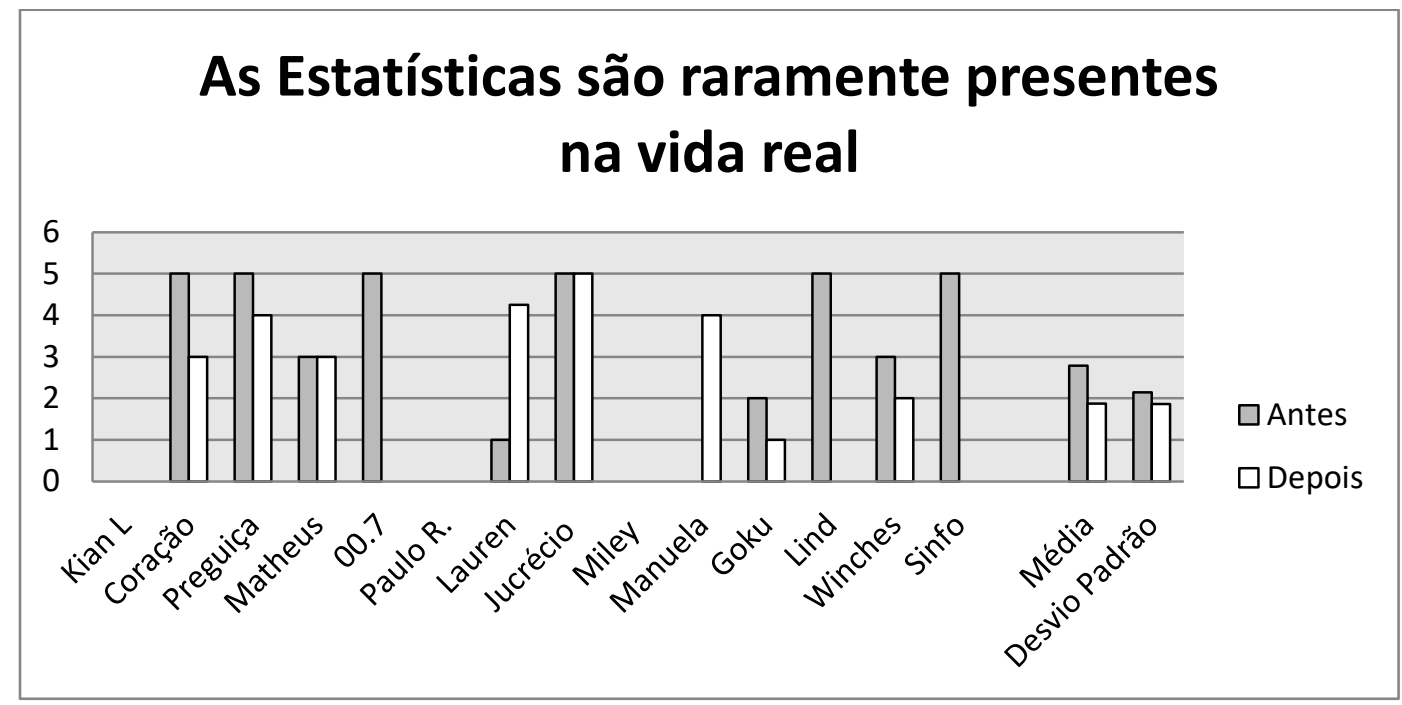

Figura 25: Teste de Atitudes - As Estatísticas são raramente presentes na vida real

Podemos perceber que as duas médias, antes e depois, ficaram próximas apesar de que a média depois acabou tendo uma queda de quase 1 ponto. $\mathrm{O}$ desvio padrão pequeno nos dois momentos se mostrou alto com quase 2 pontos, indicando que os dados possui uma variação relevante. Destacamos três alunos 007, Lind e Sinfo, que diminuíram cinco pontos depois da atividade, evidenciando que neste caso, para estes estudantes eles puderam perceber que a Estatística está bem presente na vida real.

A média depois da atividade ficou abaixo de 2 pontos, indicando que eles perceberam que as Estatística estão presentes na vida real. Devemos notar também que as estudantes Manuela e Lauren, foram as únicas que subiram as notas depois, ou seja, para eles a atividade mostrou um presença um pouco menos significante da Estatística. 


\section{8- Estatística é uma matéria difícil}

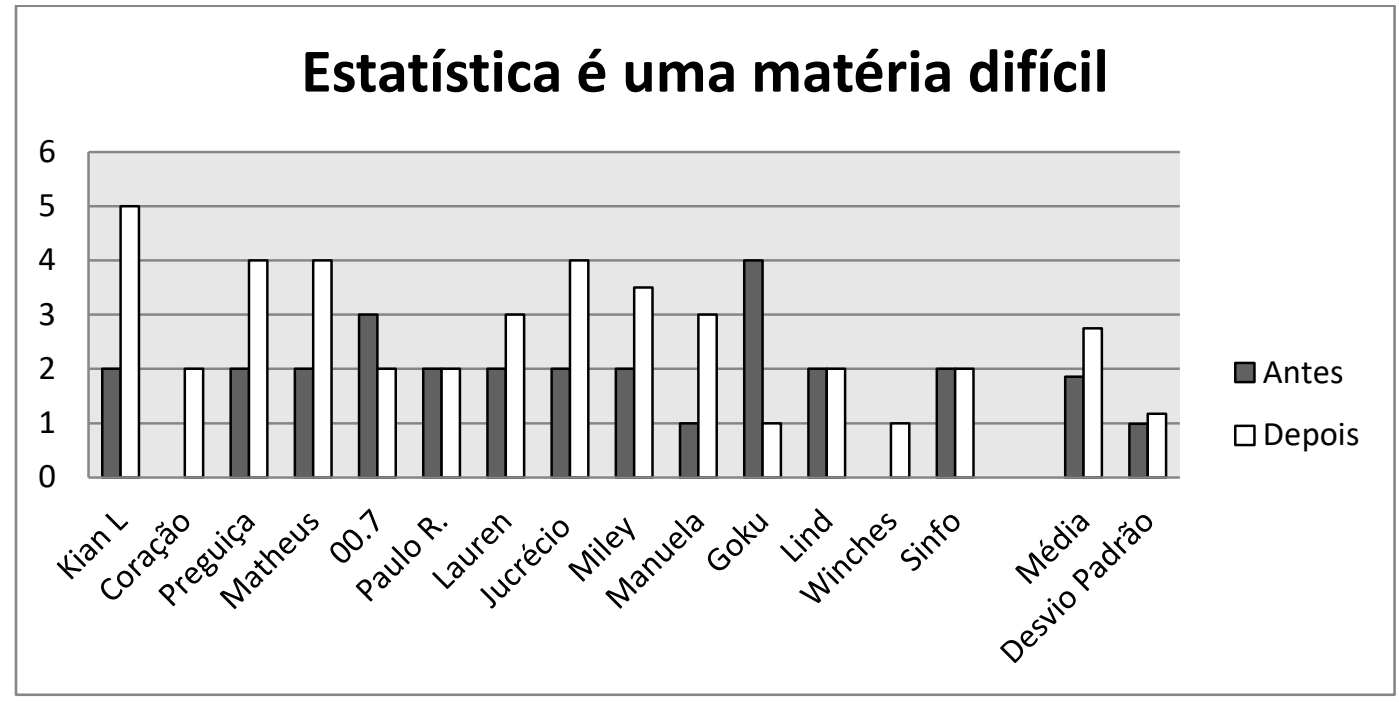

Figura 26: Teste de Atitudes - Estatística é uma matéria difícil

Podemos perceber que as duas médias, antes e depois, ficaram próximas apesar de que a média depois acabou subindo quase 1 ponto. $\mathrm{O}$ desvio padrão pequeno nos dois momentos mostra que os dados não sofreram tantas variações. Destacamos dois alunos Goku, que diminuiu três pontos depois da atividade, e Kian L, que subiu três pontos depois da atividade, evidenciando que neste caso, um considerou que a Estatística não foi uma matéria difícil e para outro que na verdade a disciplina se mostrou mais complicada do que parecia antes da atividade.

A média depois da atividade ficou próxima de 3 pontos, indicando que eles perceberam que, no geral, os alunos tenderam a subir as notas e considerar que a Estatística se mostrou um matéria mais difícil do que parecia. Isso pode estar relacionado com o fato, de que como eles nunca tinham trabalhado com um processo investigativo, que é trabalhoso, os estudantes tendem a achar mais complicado esta nova dinâmica de sala de aula e por isso acabaram conectando isto com a Estatística parecer mais difícil depois da atividade. 
9- Insegurança nos problemas de Estatística

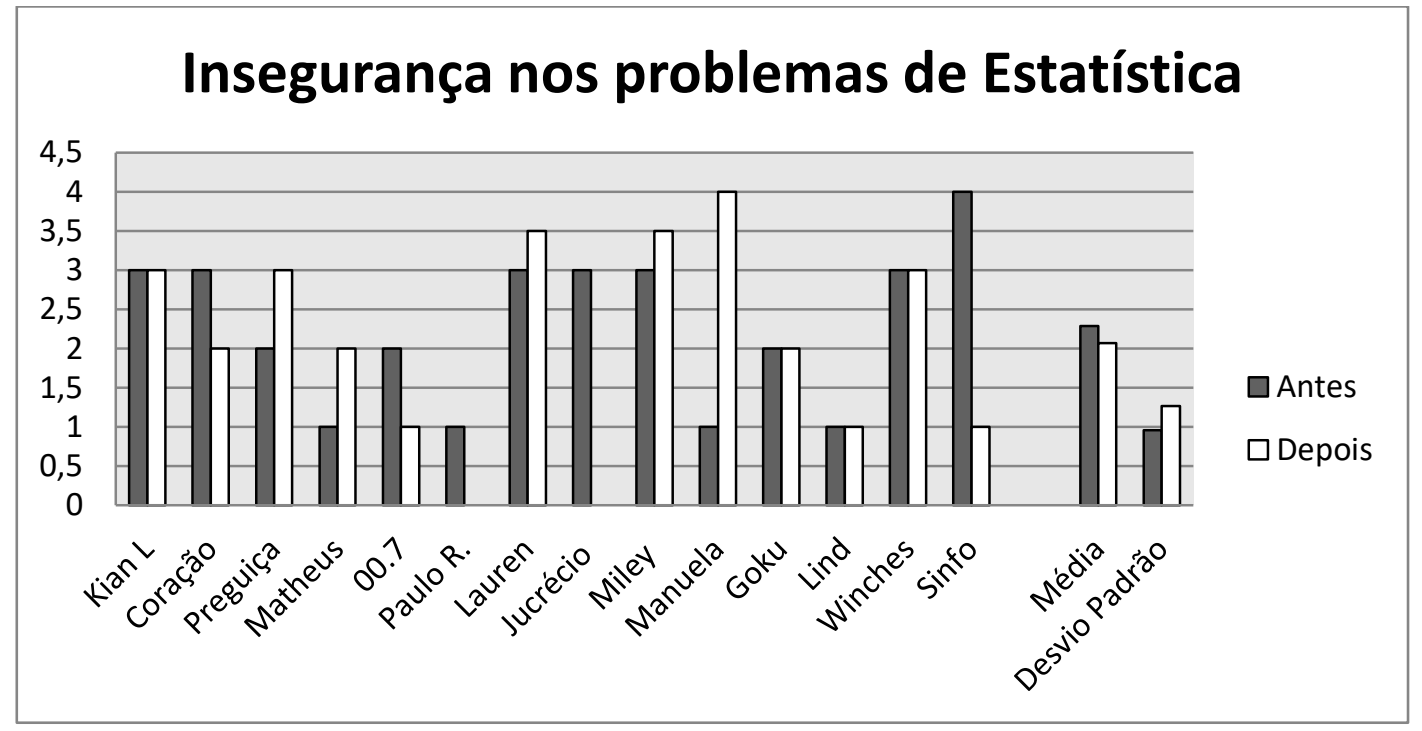

Figura 27: Teste de Atitudes - Insegurança nos problemas de Estatística

Podemos perceber que as duas médias, antes e depois, ficaram próximas. O desvio padrão pequeno nos dois momentos mostra que os dados não sofreram tantas variações. Destacamos dois alunos Manuela, que aumentou quatro pontos depois da atividade, e Sinfo, que diminuiu quatro pontos depois da atividade, evidenciando que neste caso, um considerou que se sentiu mais inseguro depois da atividade e o outro não.

A média depois da atividade ficou próxima de 2 pontos, uma média razoável que nos leva a concluir que os alunos não sentiram tanta insegurança nos problemas que foram apresentados ao longo da dinâmica em sala de aula. 
10- Estatística é irrelevante para minha vida

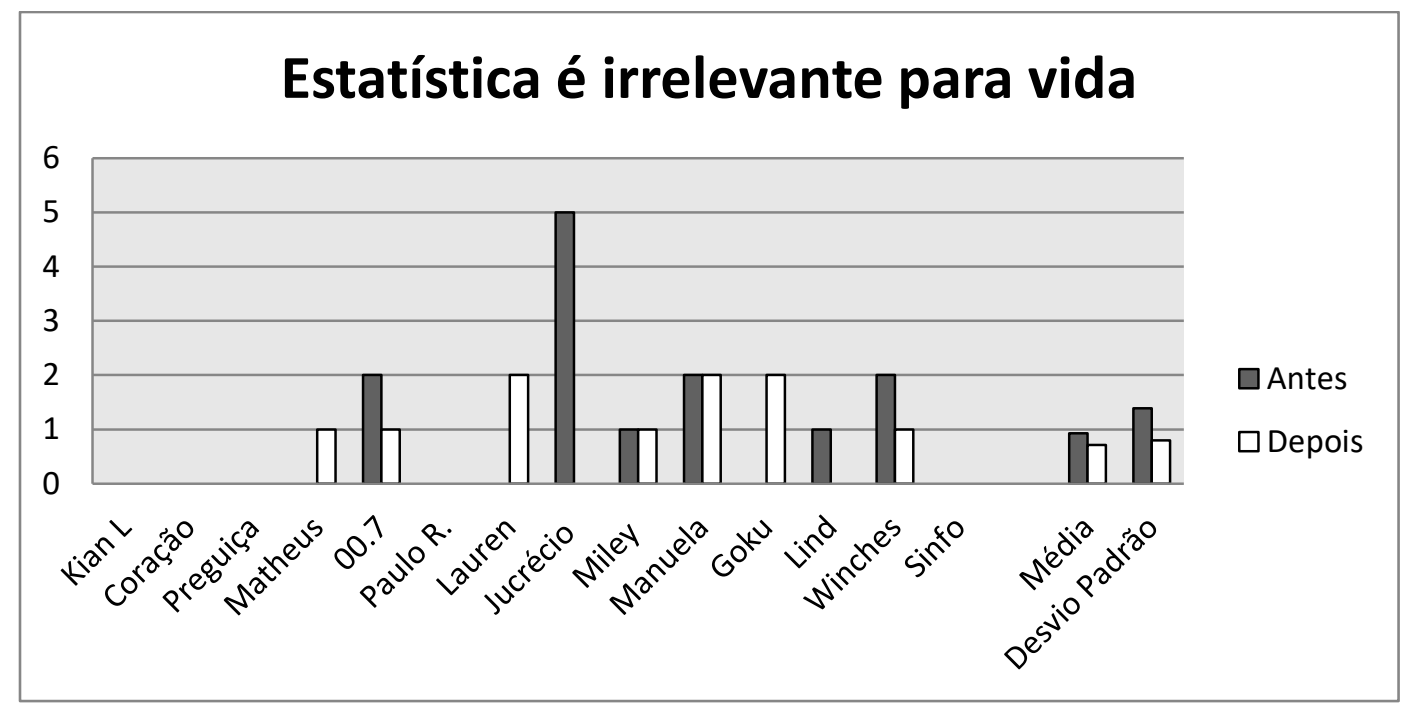

Figura 28: Teste de Atitudes - Estatística é irrelevante para vida

Podemos perceber que as duas médias, antes e depois, ficaram próximas. O desvio padrão pequeno nos dois momentos mostra que os dados não sofreram tantas variações. Destacamos o aluno Jucrécio, que diminuiu cinco pontos depois da atividade, evidenciando que para ele, a Estatística demonstrou ser bem relevante para a vida das pessoas.

A média depois da atividade ficou abaixo de 1 ponto, uma ótima média, demonstrando que no geral, os estudantes perceberam a relevância da Estatística na vida das pessoas e a importância dos seus estudos. 


\section{1- Dificuldade em compreender os conceitos de Estatística}

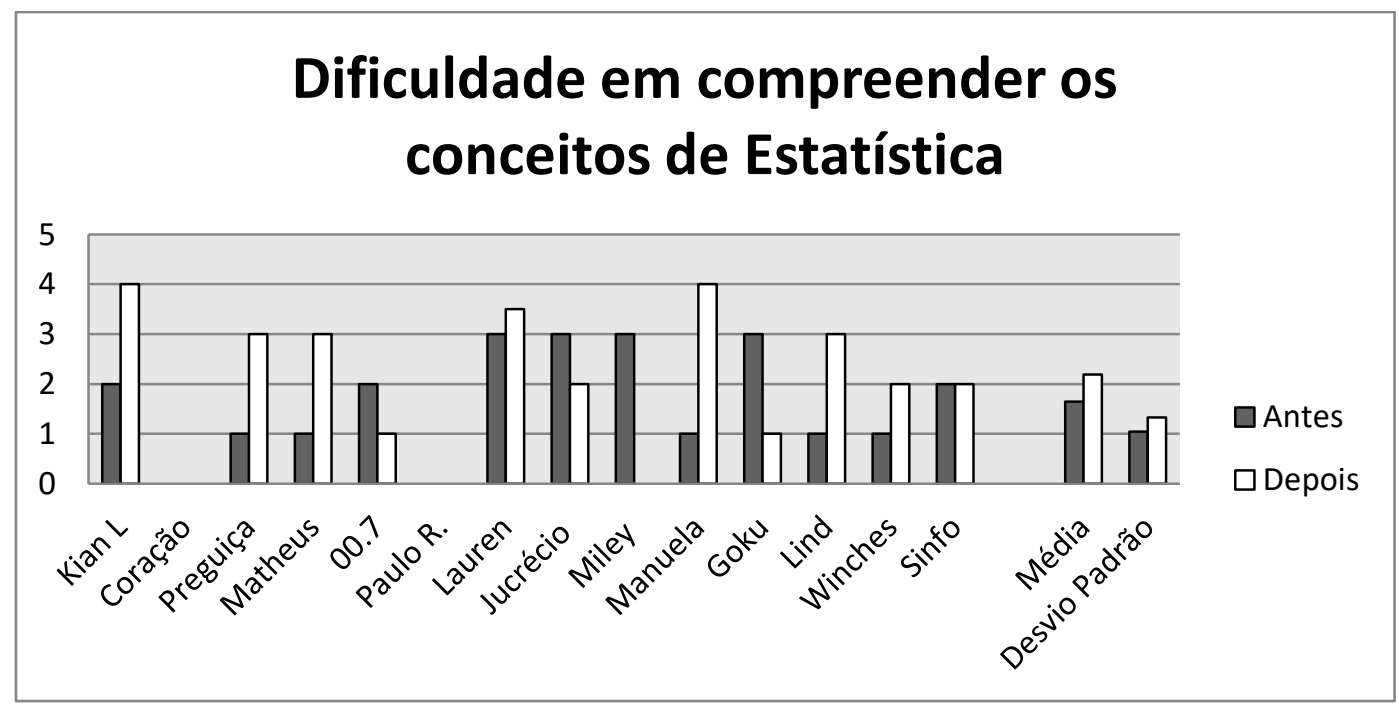

Figura 29: Teste de Atitudes - Dificuldade em compreender os conceitos de Estatística

Podemos perceber que as duas médias, antes e depois, ficaram próximas com destaque que depois, neste caso, a média teve uma ligeira subida. $\mathrm{O}$ desvio padrão pequeno nos dois momentos mostra que os dados não sofreram tantas variações. Destacamos a aluna Manuela, que aumentou três pontos depois da atividade, evidenciando que para ela, a dificuldade para compreender os conceitos de Estatística aumentou. Também devemos notas, que para a aluna Miley, que diminui três pontos, ela não teve nenhuma dificuldade em compreender os conceitos de Estatística depois da atividade.

A média depois da atividade ficou próxima de 2 pontos, uma média razoável, demonstrando que no geral, os estudantes tiveram um pouco mais de dificuldade em compreender os conceitos depois da dinâmica em sala de aula. 


\section{2- Eu fico assustado com Estatística}

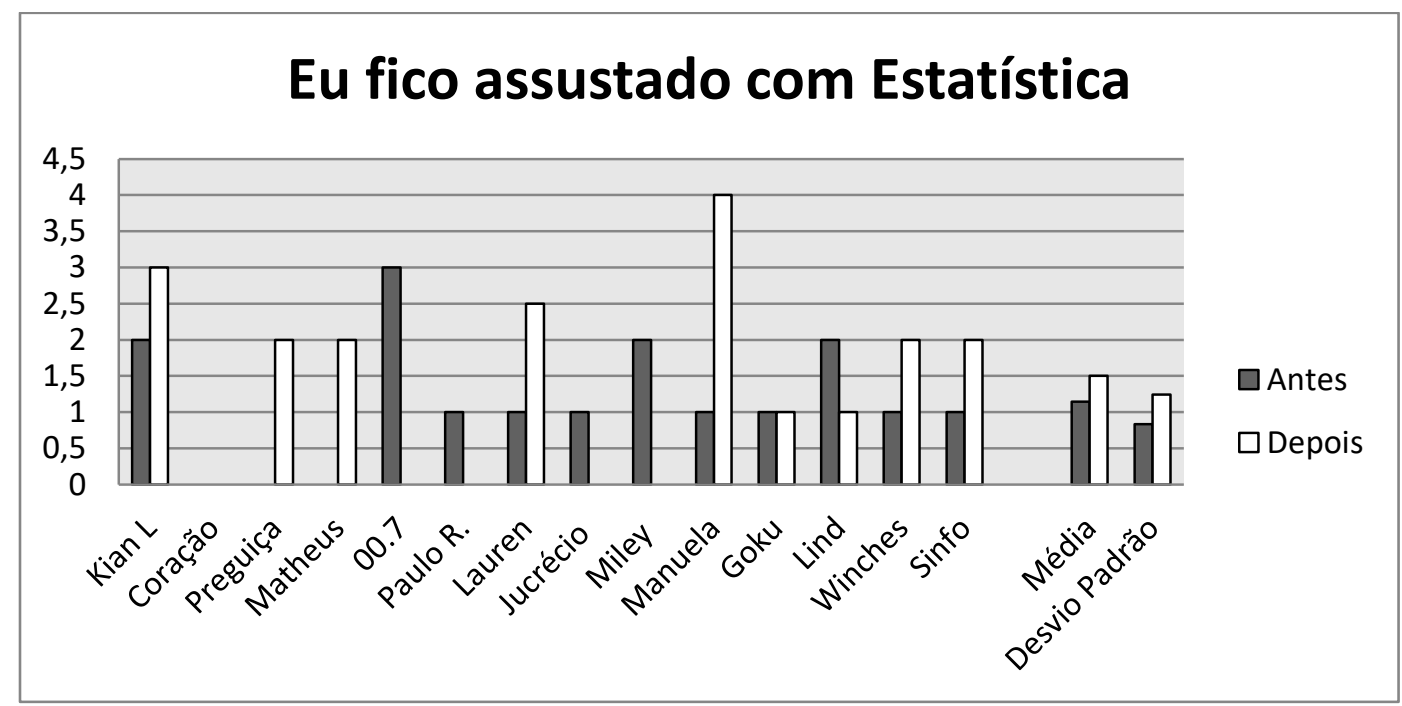

Figura 30: Teste de Atitudes - Eu fico assustado com Estatística

Podemos perceber que as duas médias, antes e depois, ficaram próximas com destaque que depois, neste caso, a média teve uma ligeira subida. $\mathrm{O}$ desvio padrão pequeno nos dois momentos mostra que os dados não sofreram tantas variações. Destacamos a aluna Manuela, que aumentou quatro pontos depois da atividade, evidenciando que para ela, se sentiu bastante assustada com a Estatística depois da dinâmica em sala de aula.

A média depois da atividade ficou próxima de 1 ponto, uma boa média, demonstrando que no geral, os estudantes não ficaram assustados com a Estatística. 